WATER LEVELS IN PERIODICALLY MEASURED WELLS

IN THE YUCCA MOUNTAIN AREA, NEVADA, 1989

By Grady M. O'Brien

U.S. GEOLOGICAL SURVEY

Open-File Report 91-178

Prepared in cooperation with the

NEVADA OPERATIONS OFFICE,

U.S. DEPARTMENT OF ENERGY, under

Interagency Agreement DE-AI08-78ET44802

Denver, Colorado

1991 


\section{U.S. DEPARTMENT OF THE INTERIOR}

MANUEL LUJAN, JR., Secretary

U.S. GEOLOGICAL SURVEY

Dallas L. Peck, Director

For additional information write to:

Chief, Yucca Mountain Project Branch U.S. Geological Survey

Box 25046, Mail Stop 425

Denver Federal Center

Denver, CO 80225-0046
Copies of this report can

be purchased from:

U.S. Geological Survey Books and Open-File Reports Section Federal Center

Box 25425

Denver, CO 80225-0425 
Abstract-10

Introduction-

Well designations-10

General description of water-level surface-1

Water-level monitoring network-

History and development-_.

Present water-level monitoring network-

History of measurement techniques used at Yucca Mountain-

Periodic measurements--

$2,800-\mathrm{ft}$ Reference steel tape-

$2,600-\mathrm{ft}$ Reeled steel tape--

Chain 非-

Multiconductor cable-Con

Corrections and adjustments

Mechanical stretch-

Thermal expansion-

Multiconductor-cable correction-

Borehole correction-

Altitude--

Example calculations-0.

Quality assurance-10

Well data, water levels, and hydrographs-

Well USW WT-1-1

Well UE-25 WT \#3

Well UE-25 WT 非4-

Well USW WT-7-10

Well USW WT-10--

Well UE-25 WT 非12

Wel1 UE-25 WT 非14-12

We11 UE-25 WT 非15-

Wel1 UE-25 WT 非17-

Wel1 USW VH-1

Well J-13-13

References cited--

Page

1

1

3

4

4

4

6

6

8

8

9

9

9

11

11

11

14

14

14

15

17

18

19

22

24

27

30

33

36

39

42

45

48

51

\section{FIGURES}

Figure 1. Map showing location of Yucca Mountain area and selected water-level altitudes-

2. Map showing location of wells and water-level altitudes in the vicinity of Yucca Mountain- 
Table 1. Summary of wells monitored for water levels

2. Corrections applicable to steel tapes used for measuring water levels in the vicinity of Yucca Mountain--- 12

3. Mechanical stretch and thermal expansion equation variable values for steel tapes used in the vicinity of Yucca Mountain---- 13

4. Borehole correction, altitude correction, and reference point for periodically measured wells in the vicinity of Yucca Mountain--

CONVERSION FACTORS AND VERTICAL DATUM

\section{Multiply}

foot ( $f t)$

kilogram (kg)

kilogram per meter $(\mathrm{kg} / \mathrm{m})$

kilometer $(\mathrm{km})$

liter (L)

liter per second $(\mathrm{L} / \mathrm{s})$

meter $(m)$

meter per meter $(\mathrm{m} / \mathrm{m})$

meter per (meter-degree

Celsius) $\left[\mathrm{m} /\left(\mathrm{m} \cdot{ }^{\circ} \mathrm{C}\right)\right]$

meter per (meter-kilogram)

$[\mathrm{m} /(\mathrm{m} \cdot \mathrm{kg})]$

millimeter $(\mathrm{mm})$

square kilometer $\left(\mathrm{km}^{2}\right)$
By

$$
0.3048
$$

2.205

0.6720

0.6214

0.2642

15.85

3.281

1

0.5556

0.4535

0.03937

0.3861
To obtain

meter (m)

pound (lb)

pound per foot ( $l b / f t)$

mile ( $\mathrm{mi}$ )

gallon (gal)

gallon per minute (gal/min)

foot ( $f t$ )

foot per foot $(\mathrm{ft} / \mathrm{ft})$

foot per (foot-degree

Fahrenheit) $\left[\mathrm{ft} /\left(\mathrm{ft} \cdot{ }^{\circ} \mathrm{F}\right)\right]$

foot per (foot:pound)

$[\mathrm{ft} /(\mathrm{ft} \cdot \mathrm{lb})]$

inch (in.)

square mile $\left(\mathrm{mi}^{2}\right)$

Temperature in degrees Celsius $\left({ }^{\circ} \mathrm{C}\right)$ can be converted to degrees Fahrenheit $\left({ }^{\circ} \mathrm{F}\right)$ as follows:

$$
{ }^{\circ} \mathrm{F}=9 / 5\left({ }^{\circ} \mathrm{C}\right)+32
$$

Sea level: In this report "sea level" refers to the National Geodetic Vertical Datum of 1929 (NGVD of 1929)--a geodetic datum derived from a general adjustment of the first-order level nets of both the United States and Canada, formerly called Sea Level Datum of 1929 . 


\title{
WATER LEVELS IN PERIODICALLY MEASURED WELLS \\ IN THE YUCCA MOUNTAIN AREA, NEVADA, 1989
}

\author{
By Grady M. O'Brien
}

\begin{abstract}
This report presents water-level data $\bar{a}^{-}$for 11 wells periodically measured during 1989 in the Yucca Mountain area. Water levels measured during 1988 and annual maximum, minimum, and average water levels from previous reports are included for reference. Discussions of the methods used and adjustments applied to obtain depths and altitudes from depth-to-water measurements are included. Water levels for each well are presented in tabular and graphical form. The altitude of the water level in the upper part of the saturated zone is about 776 meters above sea level to the west of and along part of the crest of Yucca Mountain; along the eastern edge and southern end of Yucca Mountain, the water level is 728 to 731 meters above sea level. The water-level data were obtained to help evaluate the suitability of the area for storing highlevel nuclear waste.
\end{abstract}

\section{INTRODUCTION}

The Yucca Mountain area is being evaluated by the U.S. Department of Energy for suitability to store high-level nuclear waste in a mined, underground repository (U.S. Department of Energy, 1988). A 150-km area about $150 \mathrm{~km}$ northwest of Las Vegas in southern Nevada is being studied extensively (fig. 1). The water table is in air-fall and ash-flow tuff of Tertiary age in the Yucca Mountain area, which is underlain at depth by carbonate rocks of Paleozoic age (Robison, 1984). Water levels in wells have been measured periodically since 1981 (Robison and others, 1988; Gemmell, 1990) to gain a better understanding of the hydrologic system in the area.

Methods used to collect and adjust measurements of water levels and lists of water-level altitudes for 11 wells for calendar years 1988 and 1989 are described. Historically, water-level measurements have been made at the Nevada Test Site (NTS) using steel tapes, single-conductor cables, and hoist units that use multiconductor cables. Corrections are made to the water-level measurements for thermal expansion and mechanical stretch of the steel tapes and for borehole deviation from vertical. Water-level altitudes are computed by subtracting the water-level measurement from the altitude of a reference point. Original measurements, corrections, and well information were reported in inch-pound units. Depth to water and water-level altitude were calculated using inch-pound units. All values presented here have been converted to the International System of Units (SI) except those in the "Example Calculations" 


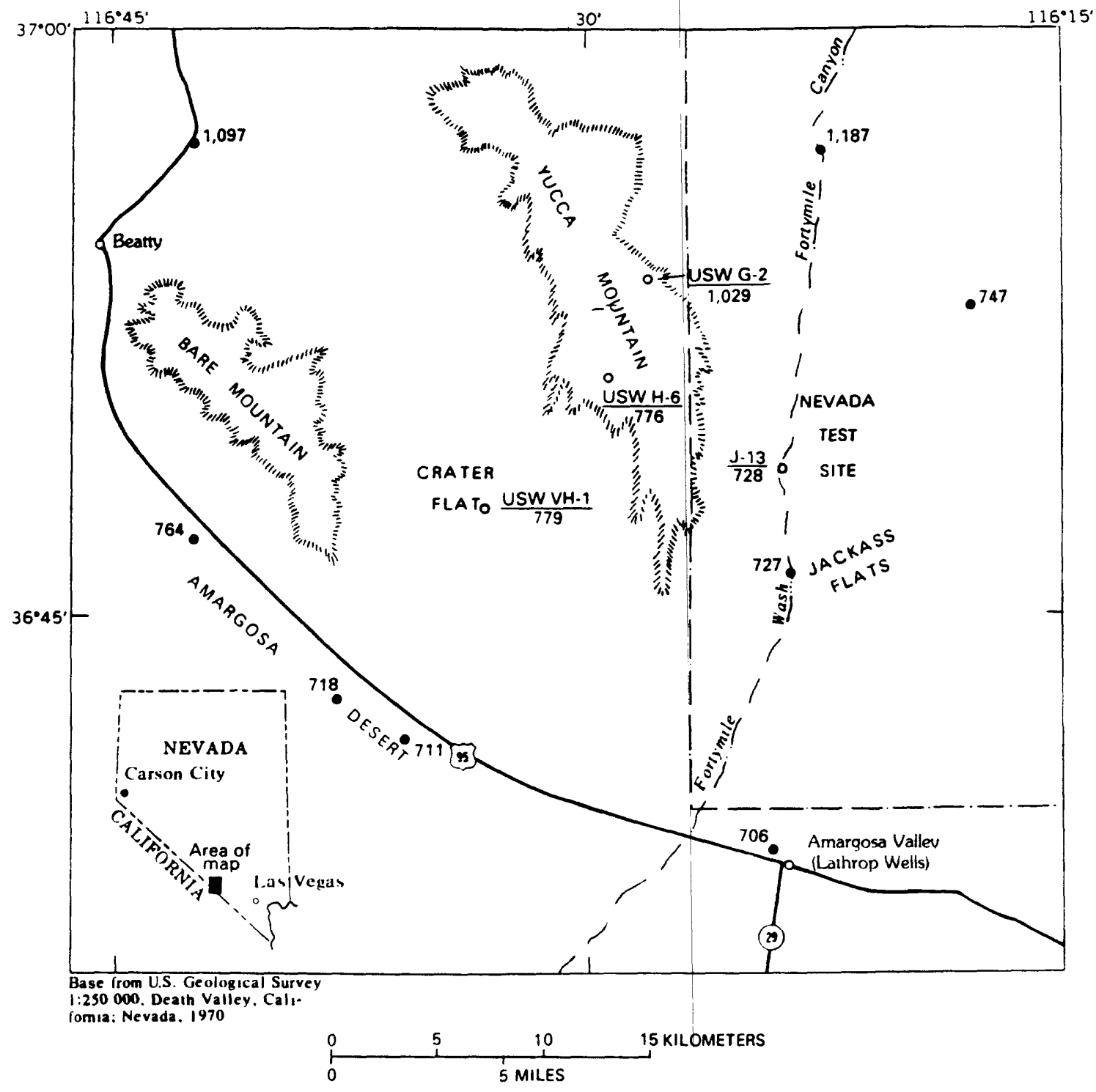

EXPLANATION

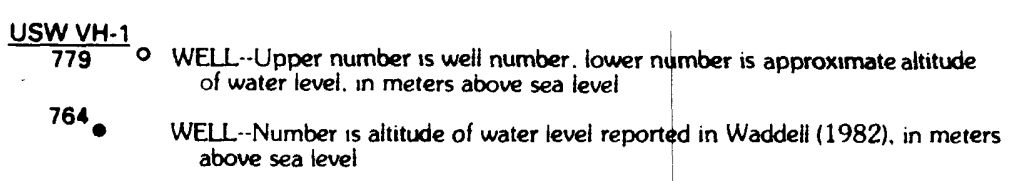

Figure 1. Location of Yucca Mountain area, and selected water-level altitudes (from Robison and others, 1988). 
section and description of multiconductor cable measurements, which have retained inch-pound units to be consistent with logbook entries. Due to the conversion process, it is not always possible to obtain the original values by converting SI units to inch-pound units. The water-level altitudes are presented in a table for each well, accompanied by a hydrograph. Data for calendar year 1988 have been included for the convenience of the reader. Data become more reliable as the equipment and techniques for measuring water levels in deep wells are refined. A trend may be developing toward a more consistent water-level record as a result of improved equipment and techniques. An examination of previously published hydrographs (Robison and others, 1988; Gemmell, 1990) seems to support this contention. Tables and graphs of annual maximum, minimum, and average water-level altitudes are included for reference. Water-level data were collected under qualityassurance procedures required for the study of Yucca Mountain as a potential site for storage of nuclear waste. The water-level data were obtained as part of the Yucca Mountain Project. This study is being conducted by the U.S. Geological Survey in cooperation with the $\bar{U} . S$. Department of Energy under Interagency Agreement DE-AI08-78ET44802.

\section{WELL DESIGNATIONS}

Each well used in the study of the Yucca Mountain area has a unique designation. Wells within the NTS use the NTS designation, whereas wells outside the NTS use a slightly different designation. Wells within the NTS begin with UE (U for underground and $E$ for exploratory), followed by the NTS area number (always 25 in this report). This designation (UE-25) commonly is followed by one or more letters signifying the purpose of the well or simply a sequential letter, followed by a sequence number. The only well not designated using this system is well J-13. Well J-13 was completed in 1963 and predates the current system of well designation.

Wells outside the NTS begin with the letters USW (U for underground, $S$ for southern Nevada, and $W$ for waste). The designation USW is followed by one or more letters signifying the purpose of the well, followed by a sequence number. The letters signifying purpose that most commonly are used in this report are $G$ (drilled primarily to collect geologic data), H (drilled primarily to collect hydrologic data), $V$ (drilled primarily to collect data on volcanism), and WT (drilled primarily to determine the water table).

Nevada State Coordinates are used to identify the location of wells cited in this report. These coordinates are for the central zone of Nevada and are based on a Transverse Mercator projection. The origin of this projection for the central zone of Nevada is lat $34^{\circ} 45^{\prime} \mathrm{N}$., and the central meridian is long $116^{\circ} 40^{\prime} \mathrm{W}$. The Nevada State Coordinates given in the section on well data are in meters north of the baseline and in meters plus 152,400 east of the central meridian. The Nevada State Coordinates for the wells were determined by Holmes \& Narver, Inc., 1 contractor to the U.S. Department of Energy for surveying at the NTS and Yucca Mountain area. Latitude and longitude values of the wells were calculated from the Nevada State Coordinates as described by Snyder (1987, p. 57-64).

${ }^{1}$ Use of $\mathrm{firm}$, brand, and trade names in this report is for identification purposes only and does not constitute endorsement by the U.S. Geological Survey. 
The site ID number is used for unique identification of the well in the U.S. Geological Survey computer files. The site ID is generated by combining the original values of the latitude and longitude of the well with a two-digit sequence number. The site ID is for convenience of identification only and cannot be used to locate a well geographically because the original values of latitude and longitude may be inaccurate. The site ID would not be changed even if original values of the latitude and longitude at a site were revised later. The two-digit sequence number is used to ensure uniqueness of the site ID if more than one well exists within the 1 -second rectangle of latitude and longitude.

\section{GENERAL DESCRIPTION OF WATER-LEVEL SURFACE}

The water-level altitude in the Yucca Mountain area ranges from about $700 \mathrm{~m}$ to about $1,200 \mathrm{~m}$ above sea level (fig. 1). Water-level altitudes beneath Yucca Mountain are shown in greater detail in figure 2; water-level altitudes are highest to the north at wells USW G-2 and UE-25 WT 非, at about $1,030 \mathrm{~m}$ above sea level. In wells USW H-6, USW WT-7, and USW WT-10, west of the crest of Yucca Mountain, and in well USW H-5 on the crest, the water-level altitudes all are about $775 \mathrm{~m}$ above sea level. Water-level altitudes are as much as $45 \mathrm{~m}$ lower at wells USW G-3 and USW H-3, about $1 \mathrm{~km}$ east of well USW WT-7. From the eastern edge and southern end of Yucca Mountain to western Jackass Flats, the water level decreases from about 731 to $728 \mathrm{~m}$ above sea level (fig. 2) and decreases further to $706 \mathrm{~m}$ at Amargosa Valley (fig. 1).

\section{WATER-LEVEL MONITORING NETWORK}

\section{History and Development}

Well drilling to collect hydrologic and geologic data for preliminary evaluation of the suitability of the Yucca Mountain site to store high-level nuclear waste began in 1980; the first wells as part of this evaluation were completed in 1981 (well UE-25a 非, completed in 1978, was drilled prior to formal evaluation of the Yucca Mountain Site). Water levels were measured as each well was completed and tested. The U.S. Geological Survey began to measure the water levels in these wells periodically to determine the stability of the original measurements and to determine if any cycles or trends in the water levels occur that may provide insight about the local hydrologic system. In addition, the nearly horizontal potentiometric surface beneath part of the area (Robison, 1984) indicated that periodic measurements for calculating long-term average water levels would be needed to determine hydraulic gradients with adequate precision. As more water levels were measured, it became apparent that periodic measurements may not be sufficient for calculating average water levels nor for determining short-term changes that could help evaluate conceptual models and mechanisms of ground-water flow beneath Yucca Mountain. In late 1983, methods for continuous water-level monitoring were initially tested at well UE-25b \#1. Methods for continuous water-level monitoring were developed for use at well USW $\mathrm{H}-1$ in 1983 and for use at well USW H-4 in 1984. By early 1985, methods were sufficiently developed to obtain usable data. By 1986, the present water-level monitoring network of continuously monitored and periodically measured wells had evolved. 


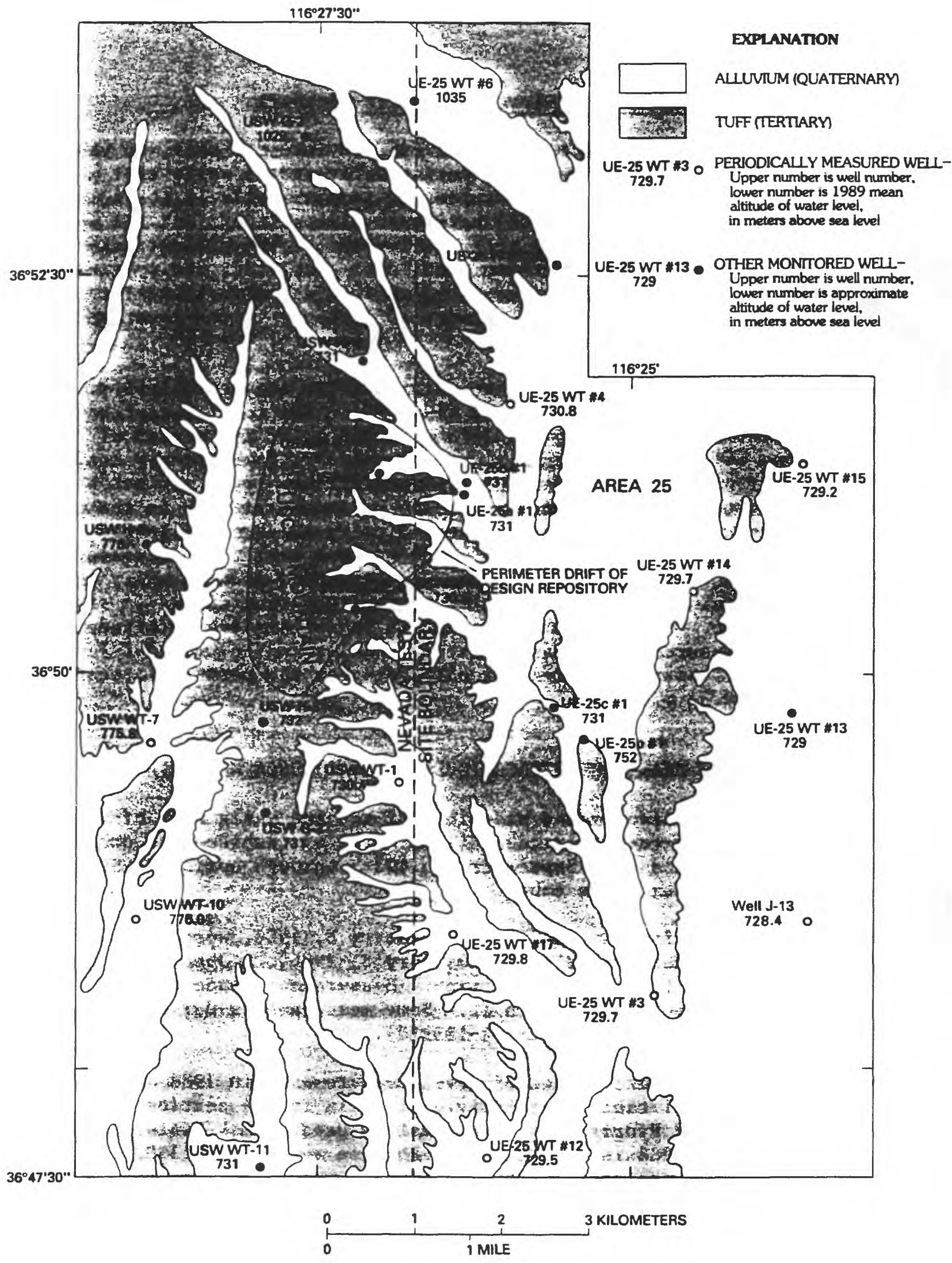

Figure 2. Location of wells and water-level altitudes in the vicinity of Yucca Mountain (modified from Robison and others, 1988). 


\section{Present Water-Leve1 Monitoring Network}

The water-level monitoring network has evolved into one that, by the end of 1989 , consisted of 11 wells measured periodically and 15 wells that are continuously monitored (table 1). Measurements in four wells in the network described by Robison and others (1988) have been discontinued; not all wells that have reported water levels are necessarily part of the present waterlevel monitoring network. The depth drilled, date completed, and water-level data for 26 wells in the present water-level monitoring network and for 4 wells removed from the network are summarized in table 1 ; the location of the wells is shown in figures 1 and 2 .

The maximum variation in water-level altitude for the periodically measured wells was measured in well J-13 (1962-89). The total variation in measured water-level altitude at well $\mathrm{J}-13$ was $0.90 \mathrm{~m}$ for the period of record. Because well J-13 is used for water supply, it is routinely subject to the effects of pumping; therefore, the measured water level may not be representative of the static water level. The maximum variation in the waterlevel altitude for the remainder of the periodically measured wells was measured in well UE-25 WT 非14 (1983-89). The maximum variation in measured water-level altitude was $0.69 \mathrm{~m}$ for the period of record at this well, which probably can be considered to represent the actual observed change in static water-level altitude. The minimum variation in the water-level altitude for the periodically measured wells was measured in well USW VH-1 (1984-89). The total variation in measured water-level altitudes for the period of record at we11 USW $\mathrm{VH}-1$ was $0.31 \mathrm{~m}$.

\section{HISTORY OF MEASUREMENT TECHNIQUES USED AT YUCCA MOUNTAIN}

Most water-level measurements made in 1981 and the early part of 1982 were made with a single-conductor cable (Iron Horse 6) (Robison and others, 1988). Most measurements from September 10, 1982, through April 29, 1985, were made with a multiconductor cable.

Most measurements from May 1985 until January 8, 1986, were made with a 2,800-ft steel tape. Measurements from January 8, 1986, to January 9, 1989, were made with a 2,600-ft reeled steel tape. Measurements made after January 9, 1989, were made with chain 非. Some measurements during 1989 were made with a multiconductor cable (van I-133970).

The method used to make the water-level measurements in 1988 and 1989 is shown in the water-level tables for individual wells in the section "Well Data, Water Levels, and Hydrographs." The method used to make water-level measurements prior to 1988 is documented by Robison and others (1988). In 1989 , chain 非 was the preferred method for making water-level measurements because of its accuracy. The multiconductor-cable unit was used when it was impractical to use the steel tape (for example, only when condensation in the access tube prevented the steel tape from being lowered to the water surface). 
Table 1.--Summary of wells monitored for water levels

[p, periodic measurements; c, continuous monitoring; d, discontinued]

\begin{tabular}{|c|c|c|c|c|c|}
\hline \multirow[b]{2}{*}{ Well number } & \multirow[b]{2}{*}{$\begin{array}{c}\text { Drilled } \\
\text { depth } \\
\text { (meters) }\end{array}$} & \multirow[b]{2}{*}{$\begin{array}{c}\text { Date } \\
\text { com- } \\
\text { pleted }\end{array}$} & \multicolumn{2}{|c|}{ Water level ${ }^{1}$} & \multirow[b]{2}{*}{$\begin{array}{c}\text { Frequency } \\
\text { monitored } \\
\text { at end of } \\
1989\end{array}$} \\
\hline & & & $\begin{array}{c}\text { Approxi- } \\
\text { mate } \\
\text { depth } \\
\text { (meters) }\end{array}$ & $\begin{array}{l}\text { Approxi- } \\
\text { mate } \\
\text { altitude } \\
\text { (meters) }\end{array}$ & \\
\hline USW WT-1 & 515 & $5-83$ & 471 & 730 & $\mathrm{p}$ \\
\hline USW WT-2 & 628 & $7-83$ & 571 & 731 & c \\
\hline $\mathrm{UE}-25$ WT 非 & 348 & $5-83$ & 300 & 730 & $\mathbf{p}$ \\
\hline $\mathrm{UE}-25$ WT 非 & 482 & $6-83$ & 438 & 731 & $p$ \\
\hline UE-25 WT 非 & 383 & $6-83$ & -280 & 1,035 & c \\
\hline USW WT-7 & 491 & $7-83$ & 421 & 776 & $\mathbf{p}$ \\
\hline USW WT-10 & 431 & $8-83$ & 347 & 776 & $\mathbf{p}$ \\
\hline USW WT-11 & 441 & $8-83$ & 363 & 731 & c \\
\hline UE-25 WT 非12 & 399 & $8-83$ & 345 & 730 & $\mathrm{p}$ \\
\hline UE-25 WT \#13 & 354 & $7-83$ & 304 & 729 & c \\
\hline UE-25 WT 非14 & 399 & $9-83$ & 346 & 730 & $\mathbf{p}$ \\
\hline UE-25 WT 非15 & 415 & $11-83$ & 354 & 729 & p \\
\hline UE-25 WT 非 16 & 521 & $11-83$ & 473 & 738 & c \\
\hline UE-25 WT 非17 & 443 & $10-83$ & 394 & 730 & $\mathbf{p}$ \\
\hline $\mathrm{UE}-25 \mathrm{a}$ 非 1 & 762 & $9-78$ & 469 & 731 & d \\
\hline UE-25b 非 1 & 1,220 & $9-81$ & 470 & 731 & c \\
\hline UE-25C 非 & 914 & $10-83$ & 400 & 731 & d \\
\hline UE-25C 非2 & 914 & $3-84$ & 402 & 730 & c \\
\hline$U E-25 c \quad$ 非 & 914 & $6-84$ & 402 & 730 & c \\
\hline $\mathrm{UE}-25 p$ 非 1 & 1,805 & $5-83$ & 362 & 752 & c \\
\hline USW G-2 & 1,831 & $10-81$ & 525 & 1,029 & d \\
\hline USW G-3 & 1,533 & $3-82$ & 750 & 731 & c \\
\hline USW G-4 & 915 & $1-83$ & 539 & 731 & d \\
\hline USW H-1 & 1,829 & $1-81$ & 572 & 731 & c \\
\hline USW $\mathrm{H}-3$ & 1,219 & $3-82$ & 752 & 732 & c \\
\hline USW $\mathrm{H}-4$ & 1,219 & $6-82$ & 518 & 730 & c \\
\hline USW $\mathrm{H}-5$ & 1,219 & $8-82$ & 703 & 775 & c \\
\hline USW $\mathrm{H}-6$ & 1,220 & $10-82$ & 526 & 776 & c \\
\hline USW VH-1 & 762 & $2-81$ & 184 & 779 & $\mathbf{p}$ \\
\hline $\mathrm{J}-13$ & 1,063 & $1-63$ & 283 & 728 & p \\
\hline
\end{tabular}

${ }^{1}$ Composite water level of saturated interval, or level of shallowest interval monitored. See section on "Well Data, Water Levels, and Hydrographs." 


\section{PERIODIC MEASUREMENTS}

Periodic water-level measurements at wells require visits by trained personnel, who perform specific operations and record the results. Frequency of measurements necessarily is a compromise between availability of personnel and cost of operation. The maximum frequency is continuous monitoring.

Operational plans during 1989 resulted in measurements about once per month at each well. Measurement frequency, however, did vary; some wells were measured less frequently because of such factors as temporary shortage of trained personnel, breakdown of equipment, or well-site inaccessibility due to road washouts.

Periodic measurements during 1989 were made using chain $\# 2$, the 2,600-ft reeled steel tape, and the multiconductor cable. The equipment and measuring techniques varied and depended on a number of factors, such as availability of equipment, well construction that limits some equipment or techniques, length of time, or number of personnel needed.

\section{2,800-ft Reference Steel Tape}

The 2,800-ft reference steel tape is a steel surveyor's chain $6.4 \mathrm{~mm}$ wide and $853 \mathrm{~m}$ long. From January 8, 1986, through 1989, this tape has been considered the reference. The steel tape is marked in feet rather than meters; therefore it is identified as the 2,800- $\mathrm{ft}$ reference steel tape. This tape is marked at $1-\mathrm{ft}$ intervals, except for the lower part, which is marked in hundredths of a foot. The reference tape is one to which other tapes or measuring equipment are calibrated. Because it is a standard, the reference tape is not routinely used for measurements to prevent undue wear or stretch. When water levels are measured using the 2,800-ft reference steel tape or other tapes that have been calibrated against this tape, the end of the tape is lowered to slightly below the estimated water level in the well until a convenient foot value on the tape is reached; this point on the tape is held against a measuring point (MP) of known altitude, such as the top of the well casing. The water level is indicated on the tape by the limit of dissolved salt previously applied to the lower part of the tape. The tape is removed from the well and the distance between the foot value held at the MP and the top of the wetted interval is calculated immediately. This distance is the apparent depth to water below the MP; the distance between the MP and the land surface is either subtracted or added to obtain the apparent depth to water below land surface. Because depths to water beneath Yucca Mountain are as great as $750 \mathrm{~m}$, it may take as long as 2 hours to obtain a single water-level measurement.

A small plumb bob, weighing about $0.45 \mathrm{~kg}$, is attached to the end of the tape to keep it hanging straight. Mechanical-stretch coefficients (because of weight of the plumb bob and the weight of the tape), thermal-expansion coefficients, and other corrections are used to obtain the actual depth to water below the land surface. These corrections are discussed in detail in the section "Corrections and Adjustments." 


\section{2,600-ft Reeled Steel Tape}

The 2,600-ft reeled steel tape, a steel surveyor's chain $6.4 \mathrm{~mm}$ wide and $792 \mathrm{~m}$ long, is similar to the $2,800-\mathrm{ft}$ reference steel tape. The measurement technique with the $2,600-f t$ reeled steel tape is similar to that with the reference steel tape. The reeled steel tape was calibrated directly to the reference steel tape, and measurements have similar accuracy and precision.

On January 10-13, 1989, consecutive water-level measurements with the $2,600-\mathrm{ft}$ reeled steel tape and the $2,800-\mathrm{ft}$ reference steel tape were made in three wells that spanned the range in water levels that are normally measured in the vicinity of Yucca Mountain. Depth to water in the three wells was approximately $216 \mathrm{~m}, 459 \mathrm{~m}$, and $752 \mathrm{~m}$. At least two measurements were made in each well with each tape. After all appropriate corrections were applied, the difference between the two sets of January measurements ranged from zero to $0.03 \mathrm{~m}$. The $2,600-\mathrm{ft}$ reeled steel tape was_removed from service after the January, 1989 , calibration was completed.

\section{Chain 非}

Chain 非 2 is a reeled steel surveyor's chain, $7.9 \mathrm{~mm}$ wide and $792 \mathrm{~m}$ long. The measurement technique with chain $\left.\right|^{2}$ is similar to the other reeled steel tapes used at Yucca Mountain. Chain 非 has replaced the 2,600-ft reeled steel tape for measuring water levels at Yucca Mountain. Experiments to determine the mechanical stretch and the average unit weight of chain $\left.\right|^{2}$ were conducted November 30 and December 1, 1988. Chain 非 was calibrated directly to the $2,800-\mathrm{ft}$ reference steel tape January 11-13, 1989, prior to use for measuring water levels. Water-level measurements were obtained consecutively with the $2,800-\mathrm{ft}$ reference tape and chain 非. The measurements were taken in three wells with approximate depths to water of $216 \mathrm{~m}, 459 \mathrm{~m}$, and $752 \mathrm{~m}$. Chain 非 measurements ranged from 0.01 to $0.04 \mathrm{~m}$ difference from the reference tape after all appropriate corrections were applied. These data indicated that chain $\# 2$ has accuracy and precision similar to the reference steel tape. Chain 非 2 was calibrated to the 2,800-ft reference steel tape on December 12 , 1989 , at three wells with depths to water of approximately $216 \mathrm{~m}, 459 \mathrm{~m}$, and $704 \mathrm{~m}$. The measurements ranged from $0.02-$ to $0.03-\mathrm{m}$ difference after all appropriate corrections were applied. Corrections applied to water-level measurements are discussed in the section "Corrections and Adjustments."

\section{Multiconductor Cable}

Water condensation in the tube, or possibly pipe-joint compound, causes friction between the flat steel tape and the tube, inhibiting insertion of the tape in some wells with small-diameter access tubes, even with the standard plumb bob attached to the end of the tape. When this happens, the water-level measurements are made with the multiconductor-cable unit.

A four-conductor, armored cable, about $1,000 \mathrm{~m}$ long, mounted on a powered reel and housed in a truck or mobile van uses one of several different possible sensing devices attached to the end to indicate contact with the water. The cable passes over a sheave that indicates depth in feet. The water-level sensing device may be a float switch or similar device used to indicate electrical contact with water, or a pressure transducer used to indicate initial submergence. 
The probe or tool that contains the sensing device also functions as a weight to keep the cable taut as it is lowered into the well. The length of this probe can vary depending on the weight deemed necessary for maintaining a rigid cable during measurement of a particular well. Variations in probe lengths used at the NTS range from about 0.5 to $2.4 \mathrm{~m}$. Check measurements made with probes of various length indicate that the calibration of the cable unit is not significantly affected by small variations in weight. The top of the probe, as it is suspended at the top of the well and level with the MP, is used as the reference to zero on the depth indicator of the cable unit. This requires a careful measurement of the distance from the top of the probe to the actual sensor location within the probe so that the indicated depth to water on the depth counter can be corrected for the probe length. A measurement is made by initially setting the depth indicator to zero when the top of the probe containing the sensing device is level with the MP and then lowering the probe until the sensing device reaches the water surface to obtain an IN reading. The IN reading is the indicated footage of cable displayed by the depth indicator when the sensing device is at the water surface. The cable is then withdrawn and an OUT reading is obtained when the top of the probe is again level with the MP. The IN reading plus the difference between the IN and OUT reading is equivalent to measuring the actual length of cable withdrawn from the well. Frequently, as the probe containing the sensing device is withdrawn to the MP to obtain an OUT reading, the depth indicator returns to slightly past zero; when this occurs, the value indicated by the depth indicator is recorded in the field logbooks as a number slightly less than 100 , reflecting the final four digits displayed on the depth indicator. For example, a recorded OUT reading of $99.70 \mathrm{ft}$ is actually $-0.30 \mathrm{ft}$, and $-0.30 \mathrm{ft}$ is the value subtracted from the IN reading in the calculation.

The multiconductor-cable unit in use during 1989 was purchased in mid1985 and was housed in van I-133970. Although this unit is similar to other units used previously, the calibration for each unit is unique and care must be taken to not confuse the various units when calculating water-level altitudes. The multiconductor-cable unit was calibrated on January 10-i1, 1989. Water-level measurements were made in three wells with approximate depths to water of $216 \mathrm{~m}, 459 \mathrm{~m}$, and $752 \mathrm{~m}$, using the 2,800-ft reference steel tape and the multiconductor-cable unit. The multiconductor-cable unit was again calibrated on December 12 and 15, 1989. Water-level measurements were made in three wells with approximate depths to water of 216,459 , and $704 \mathrm{~m}$. At least two measurements were made using both the $2,800-\mathrm{ft}$ reference steel tape and the multiconductor-cable unit in each of the three wells. The $2,800-\mathrm{ft}$ reference steel tape measurements were corrected for mechanical stretch and thermal expansion and compared with those made using the multiconductor-cable unit to define the difference between the two sets of measurements. Using the calculated differences in the water-level measurements for the three wells, an average correction factor was computed for the multiconductor-cable unit. The correction values are discussed in detail in the section "Corrections and Adjustments." Based on the January and December 1989 calibrations, a correction factor of $+0.00162 \mathrm{~m} / \mathrm{m}$ was used to correct all measurements in 1988-89 made using the multiconductor-cable unit (van I-133970). 


\section{Corrections and Adjustments}

Various factors affect the accuracy of periodic water-level measurements and must be considered in the process of determining the apparent depth below land surface, the true depth below land surface, and the water-level altitude. All measurements in this report have been corrected to indicate the true water-level altitude. The correction factors applied to steel-tape measurements for each well are summarized in table 2 .

Corrections made for steel-tape water-level measurements include mechanical stretch and thermal expansion of the tape. All measurements are corrected for borehole deviation from vertical and to sea level datum. Multiconductor-cable measurements are corrected using the appropriate factor multiplied by the length of cable.

\section{Mechanical Str̄etch}

Mechanical stretch is associated with the weight of the steel tape and attached plumb bob or multiconductor cable and attached probe (Garber and Koopman, 1968). The calculated adjustment for the steel tapes used during 1989 , based on stretch coefficients and an approximate weight of $0.45 \mathrm{~kg}$ for the plumb bob, ranged from -0.019 to $-0.054 \mathrm{~m}$ for water levels measured in the vicinity of Yucca Mountain. This mechanical stretch may be several tenths of a meter or more for the multiconductor cable; however, no additional correction was used because the cable had been calibrated to the reference steel tape. The mechanical stretch coefficient is used to correct apparent depth values.

The correction for mechanical stretch of the tape is given by:

$$
C=\frac{I^{2} W S}{2}+P L S-K L S
$$

where $\mathrm{C}$ is the correction, in meters;

$L$ is the apparent length of tape, in meters;

$W$ is the unit weight of the tape, in kilograms per meter;

$\mathrm{S}$ is the stretch coefficient, in meters per (meter-kilogram);

$P$ is the weight of the plumb bob, in kilograms; and

$\mathrm{K}$ is reference tension during manufacture, in kilograms.

\section{Thermal Expansion}

Thermal expansion of a steel tape or a multiconductor cable occurs because of downhole change in temperature. The calculated correction for thermal expansion for steel tapes is based on manufacturer specifications for thermal-expansion coefficients and on temperature profiles in wells at Yucca Mountain (Sass and Lachenbruch, 1982). The correction ranges from +0.008 to $+0.038 \mathrm{~m}$ in periodically measured wells and usually is not made separately from other corrections. Based on the range in temperature and depths to water at Yucca Mountain, a correction of as much as $0.053 \mathrm{~m}$ may be required. No correction for thermal expansion is made for the multiconductor cable. Some temperature correction may be accounted for in the cable correction factor because the cable was calibrated in the temperature range in which it is used. 


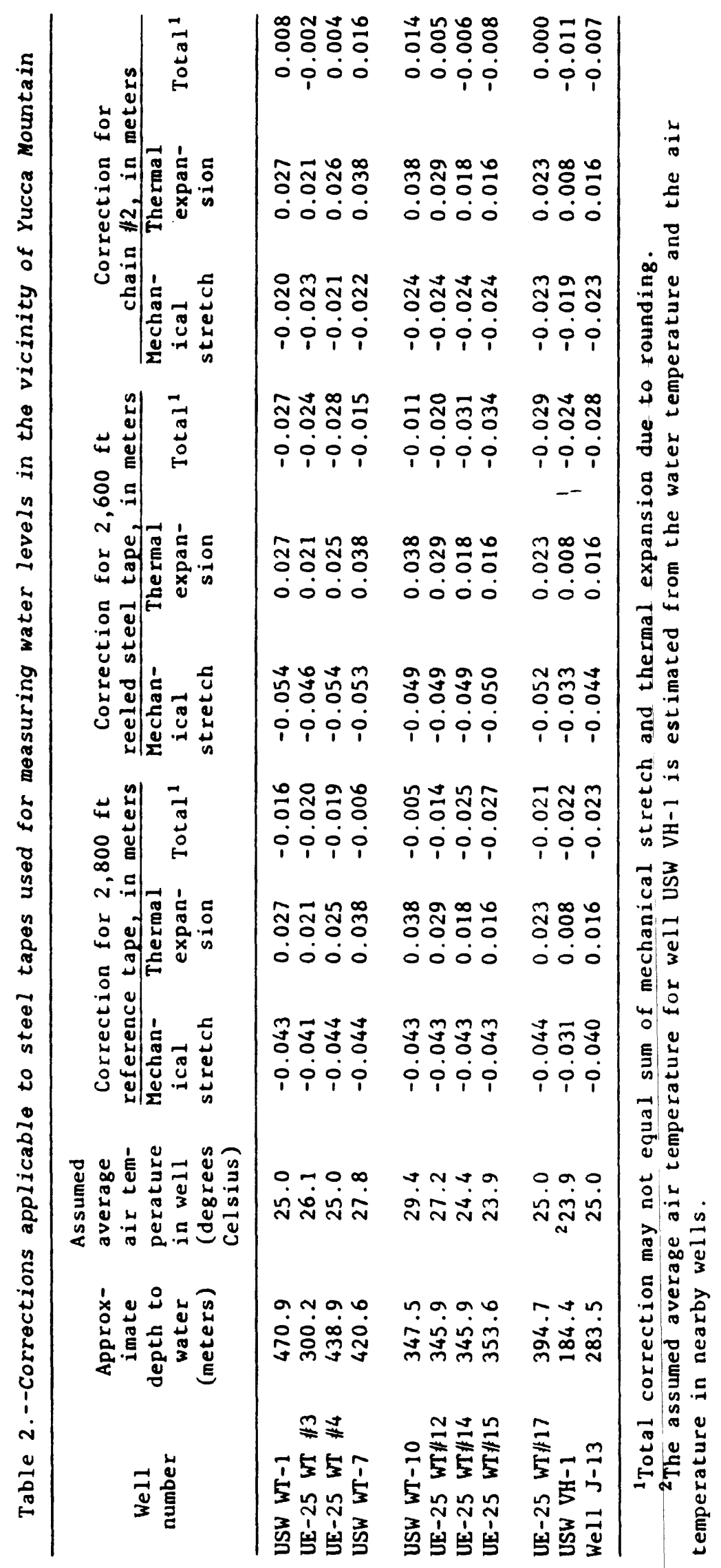


Correction for thermal expansion of the tape is given by:

$$
E=(D-R) T L,
$$

where $E$ is the correction, in meters;

$D$ is the assumed average air temperature in the well, in degrees Celsius;

$R$ is the reference temperature during manufacture, in degrees Celsius;

$T$ is the thermal expansion coefficient, in meters per (meter-degree (elsius);

$L$ is the apparent length of the tape, in meters.

The tape correction, which includes mechanical stretch and thermal expansion, values for approximate depth to water, and assumed average air temperature in the well, are given in table 2. Approximate depth to water is analogous to apparent length of the tape, $L$, in equations 1 and 2 . The tape-dependent variables for equations 1 añd 2 are defined for each tape in table 3 .

Table 3.--Mechanical stretch and thermal expansion equation variable values for steel tapes used in the vicinity of Yucca Mountain

\begin{tabular}{|c|c|c|c|}
\hline Variable & $\begin{array}{l}2,800-\mathrm{ft} \\
\text { Reference steel } \\
\text { tape }\end{array}$ & $\begin{array}{l}2,600-f t \\
\text { Reeled steel } \\
\text { tape }\end{array}$ & Chain 非2 \\
\hline $\begin{array}{l}\text { Unit weight of } \\
\text { the tape, W } \\
\text { (kilogram/meter) }\end{array}$ & $2.08 \times 10^{-2}$ & $1.70 \times 10^{-2}$ & $2.59 \times 10^{-2}$ \\
\hline $\begin{array}{l}\text { Stretch coefficient, } \\
\text { S [meter/(meter. } \\
\text { kilogram)] }\end{array}$ & $2.48 \times 10^{-5}$ & $2.50 \times 10^{-5}$ & $1.66 \times 10^{-5}$ \\
\hline $\begin{array}{l}\text { Weight of plumb bob, } \\
P \text { (kilogram) }\end{array}$ & 0.45 & 0.45 & 0.45 \\
\hline $\begin{array}{l}\text { Reference tension } \\
\text { during manufacture, } \\
\text { K (kilogram) }\end{array}$ & 9.07 & 9.07 & 9.07 \\
\hline $\begin{array}{l}\text { Reference temperature } \\
\text { during manufacture, } R \\
\text { (degree Celsius) }\end{array}$ & 20 & 20 & 20 \\
\hline $\begin{array}{l}\text { Thermal expansion } \\
\text { coefficient, } \mathrm{T} \\
\text { [meter/(meter } \cdot \text { degree } \\
\text { Celsius)] }\end{array}$ & $1.16 \times 10^{-5}$ & $1.16 \times 10^{-5}$ & $1.16 \times 10^{-5}$ \\
\hline
\end{tabular}




\section{Multiconductor-Cable Correction}

The multiconductor cable unit used during 1989 was purchased in mid-1985 and is housed in van I-133970. The calibrations used to correct the data were performed during January 10-11 and December 12 and 15, 1989. Measurements were made with the multiconductor unit and the reference tape in three wells with approximate depths to water of $216 \mathrm{~m}, 459 \mathrm{~m}$, and $752 \mathrm{~m}$. An average correction factor was calculated using the two sets of measurements to make the multiconductor-unit measurements consistent with the reference tape. The average correction factor for the multiconductor-cable unit was determined to be $+0.00162 \mathrm{~m} / \mathrm{m}$ for the January 1989 and December 1989 calibrations. The multiconductor-cable unit was used for measurements in January and February 1989.

The correction factor is applied directly to the apparent length of cable measured before other corrections are applied to arrive at the true waterlevel altitude. For example, if the apparent length of the cable was $183.45 \mathrm{~m}$ in January 1989, the corrected depth to wäter would have been:

$$
\begin{aligned}
\text { Corrected length of cable } & =183.45 \mathrm{~m}+(183.45 \mathrm{~m} \times 0.00162 \mathrm{~m} / \mathrm{m}) \\
& =183.45 \mathrm{~m}+0.30 \mathrm{~m} \\
& =183.75 \mathrm{~m}
\end{aligned}
$$

Sheave slippage occurs with the multiconductor cable because of change in diameter of the sheave or operator error. Slippage can vary with hoist design, but errors can be minimized by comparing the IN and OUT readings of water levels. The sheaves used for depth indicators can wear, eventually causing measurement errors. Annual calibration of the multiconductor-cable unit decreases this error and, along with a visual inspection of the sheave, indicates when the sheave needs to be replaced. This factor is not applicable to steel tapes that have permanently marked units.

\section{Borehole Correction}

Factors that affect determination of the true depth to water below land surface include the above factors, plus corrections for boreholes that are not vertical. Gyroscopic surveys were made in all periodically measured wells except well J-13. The gyroscopic surveys determined borehole deviation from vertical and the difference between measured depth and true vertical depth. This difference is the borehole correction. Corrections for most wells are $-0.2 \mathrm{~m}$ or less, but they range from -0.03 to $-0.48 \mathrm{~m}$ (table 4 ). Corrections generally increase with increasing well depth. Previously reported borehole corrections for wells UE-25 WT 非 and UE-25 WT \#12 have been revised and are presented in table 4 .

\section{Altitude}

Factors that affect determination of water-level altitude include the apparent-depth and true-depth factors. Water-level altitude is calculated by subtracting the true depth to water from the altitude of the land surface or the reference point, or from the altitude of the measuring-point datum, adjusted to land surface or the reference point. Measuring-point and reference-point values for periodically measured wells are given in table 4 . Water-level altitudes in this report are based on a survey of the water-level monitoring network in late 1984 by the U.S. Geological Survey. 
Table 4.--Borehole correction, altitude correction, and reference point for periodically measured wells in the vicinity of Yucca Mountain

[Hole deviation and measuring point are reported to 0.001 meter; the accuracy probably is less than 0.001 meter. The values reported were used in the calculations ]

\begin{tabular}{lccc}
\hline We11 number & $\begin{array}{c}\text { Correction for hole } \\
\text { deviation from vertical } \\
\text { (meters) }\end{array}$ & $\begin{array}{c}\text { Measuring } \\
\text { point } \\
\text { (meters) }\end{array}$ & $\begin{array}{c}\text { Reference } \\
\text { point } \\
\text { (meters) }\end{array}$ \\
\hline USW WT-1 & -0.327 & 0.314 & $1,201.11$ \\
UE-25 WT \#3 & -0.271 & 0.155 & $1,030.11$ \\
UE-25 WT 非 & -0.454 & 0.311 & $1,169.21$ \\
USW WT-7 & -0.034 & 0.302 & $1,196.88$ \\
USW WT-10 & -0.030 & 0.314 & $1,123.40$ \\
UE-25 WT作12 & -0.182 & 0.305 & $1,074.74$ \\
UE-25 WT 14 & -0.087 & 0.311 & $1,076.05$ \\
UE-25 WT作15 & -0.188 & 0.314 & $1,082.94$ \\
UE-25 WT非17 & -0.481 & 0.158 & $1,124.06$ \\
USW VH-1 & -0.050 & 0.314 & 963.23 \\
We11 J-13 & $1-0$ & 0.165 & $1,011.47$ \\
\hline
\end{tabular}

${ }^{1}$ No gyroscopic survey data are available for well $\mathrm{J}-13$; no correction is made for borehole deviation from vertical.

\section{Example Calculations}

Two measurements for well UE-25 WT 非 4 are presented to illustrate the calculations that are made to derive the true altitude of the water level. The true altitude is the value reported in the section "Well Data, Water Levels, and Hydrographs." Measurements made in January and April 1989 were chosen as the examples.

Water-level measurements at well UE-25 WT 非 4 are taken from the top of a $61-\mathrm{mm}$ inside-diameter steel tube, which is the MP. The measurements are corrected to the reference point, which at this well is the top of a metal tag welded to the casing. Because the precise altitude of the reference point is known, it is used as a basis for determining the true altitude of the water level in the well. The difference in altitude between the MP and the reference point can be measured with a pocket tape; at well UE-25 WT 非 the MP is $0.311 \mathrm{~m}$ above the reference point. The water-level measurements, which are recorded to the nearest $0.01 \mathrm{ft}$, are later converted to meters.

At least two measurements of the water level are made and averaged during each visit to the well. In most instances, additional measurements are made if the values differ by more than $0.05 \mathrm{ft}$. Some judgement is required in applying this criterion to some of the more difficult wells to measure. Even in the worst instance, the difference between measurements is limited to $0.10 \mathrm{ft}$. The appropriate corrections are applied after averaging. 


\section{Example A}

The water-level measurement on April 25, 1989, at UE-25 WT 非 was made with chain 非. The HELD is the indicated footage on the tape when it is held at the MP during a measurement, and CUT is the footage of tape that is wetted during its submersion in the water. The difference between HELD and CUT is the apparent depth to water below the MP.

The readings for UE-25 WT 非 on April 25, 1989, were:

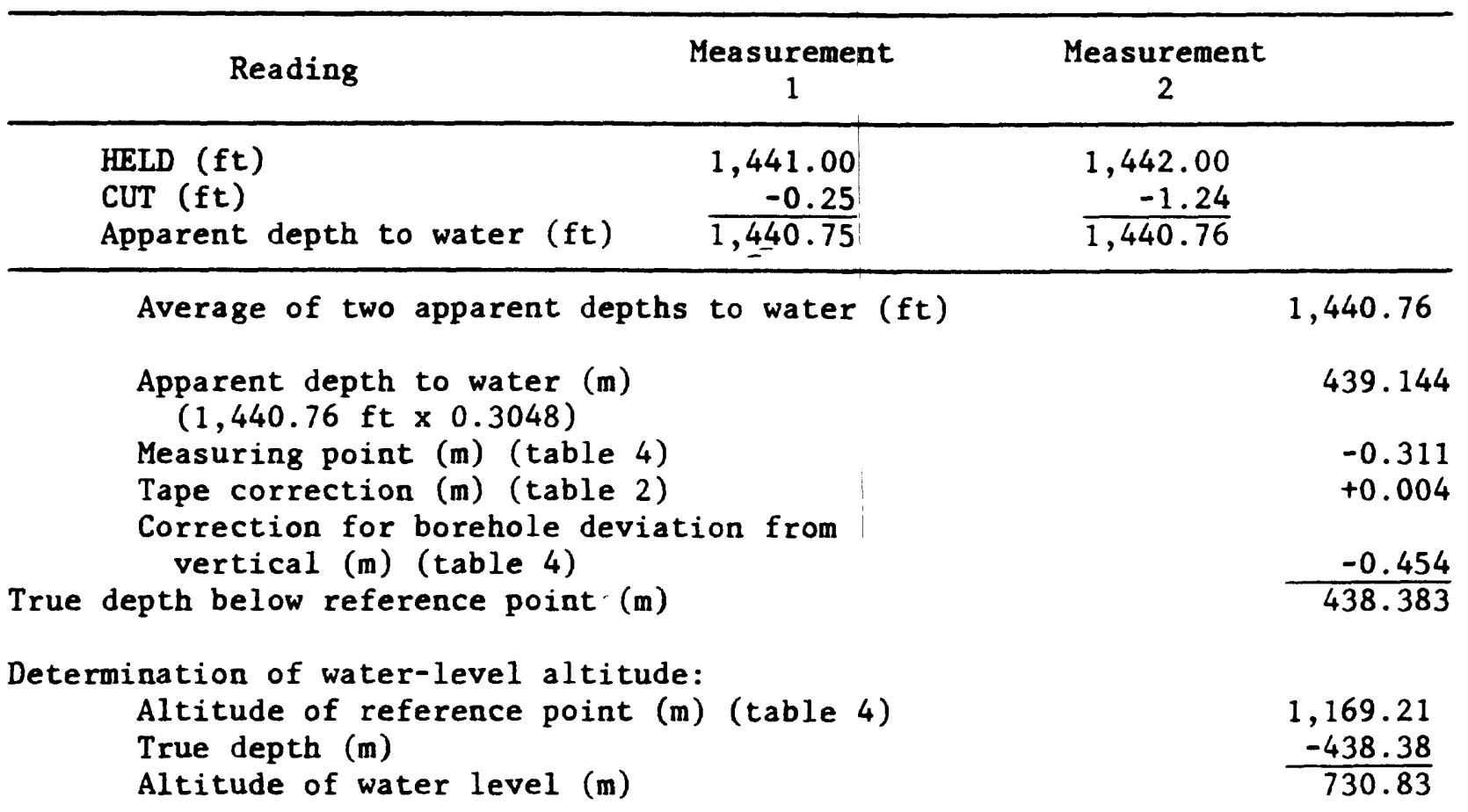

Example B

The water-level measurement on January 9, 1989, at UE-25 WT 非 was made with a multiconductor cable (housed in van $\mathrm{I}-133970$ ). The IN reading is the indicated footage of cable displayed by the depth indicator when the sensing device is at the water surface, and the OUT reading is the indicated footage when the sensing device has been withdrawn to the MP. The length of the probe containing the sensing device was also considered in the measurement because it is not accounted for in the depth-indicator reading. This length was measured using a pocket tape, and care was taken to ensure the measurement was from the top of the probe to the actual sensing point (not necessarily the bottom of the probe). 
The readings for UE-25 WT 非 on January 9, 1989, were:

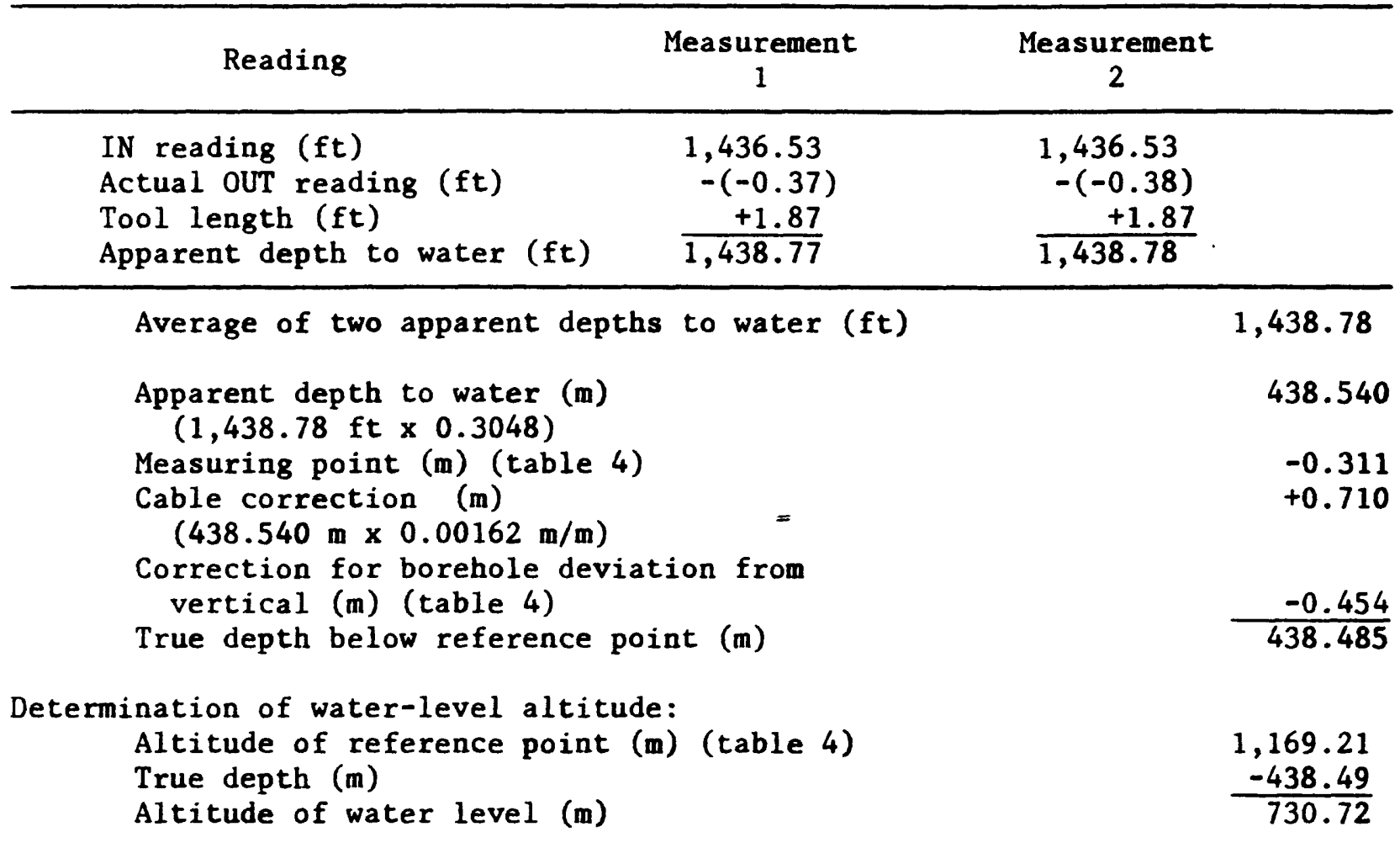

\section{Quality Assurance}

Adequate confidence in the reliability of collection, processing, and reporting of the water-level data is necessary so that the data can be used in assessing the expected performance of a potential repository. Quality assurance includes all the actions and records of those actions supporting the reliability of the data. Water-level measurements are obtained by methods described in formal technical procedures. The technical procedures include tests and adjustments performed during the measuring operation that ensure the equipment is operating properly and that expected precision and accuracy will be attained. For example, the quality assurance procedure for multiconductorcable measurements stipulates:

1. That at least two measurements be made.

2. How the measurements are to be made.

3. That the accuracy of the measurements be within at least 0.1 percent of the depth to water.

4. How the data are to be recorded on forms or in logbooks.

5. That the multiconductor-cable unit be calibrated annually.

Data are recorded at the well site in bound logbooks. Data recorded in the logbooks are designation of the well name; time and date of the measurement; names of the personnel making the measurement; identification of procedures and specific measuring equipment used; adjustments from the MP to the land surface or reference point; and the actual measurement. 
In addition to recording the detailed information in a logbook, the entry might include comments about anything that seems relevant to the data, such as discussion of problems with equipment or temporary inaccessibility of the well site. Air temperature and barometric pressure are commonly recorded in the logbook; these indicate atmospheric conditions under which the measurement is made.

The measurement information is reviewed for completeness and accuracy by the supervisor responsible for onsite operations. The original logbooks and records are maintained at the onsite operations headquarters near Mercury, Nevada. Photocopies are made periodically and transmitted to the project office in Denver, Colorado. The transmitted records are reviewed and necessary adjustments or corrections are included that were not made during onsite operations. It is at this stage that true water-level altitude is calculated. After this review and calculation, the data are ready for publication by the U.S. Geological Survey. The water-level data are also available for transfer to a computer data base, such as the Ground Water Site Inventory (GWSI) system used by the U.S. Geological Survey.

\section{WELL DATA, WATER LEVELS, AND HYDROGRAPHS}

References or information sources; well specifications; history of instrumentation and water-level measurements, and comments; periodic measurements and hydrographs of water-level altitude; annual maximum, minimum, and average water-level altitudes; and bar graphs are presented for individual wells. The sources of information, published or unpublished, are indicated for each well; the published sources are also listed in "References Cited" at the back of the report. The well specifications include location, landsurface altitude, start and completion dates of drilling, drilling method, depth drilled, bit diameter below water level, casing extending below water level, description of access tubes for measuring water levels, description and altitude of reference point, description and height of MP above reference point, and depth correction for borehole deviation. The section "History of instrumentation and water-level measurements, and comments," will aid in resolving any apparent anomalies in the water-level data that may have resulted from outside influences, such as recording errors or effects from pumping. 


\section{We11 USW WT-1}

1. References or information sources: Robison (1984, 1986); Robison and others (1988); Holmes \& Narver, Inc. (written commun., 1986); Fenix \& Scisson, Inc. (1986a, 1987).

2. Well specifications:

a. Location:

Nevada State Central Zone Coordinates (m): N 229,801; E 171,828. Latitude and longitude: $36^{\circ} 49^{\prime} 16^{\prime \prime} \mathrm{N}$.; $116^{\circ} 26^{\prime} 56^{\prime \prime} \mathrm{W}$. Site ID: 364916116265601.

b. Land-surface altitude: 1,201.4 m (Robison, 1986; based on survey by U.S. Geological Survey in 1984).

c. Date drilling started: April 28, 1983.

d. Date drilling completed: May 18, 1983.

e. Drilling method: Rotary, using rock bits and air, water, and soap circulating medium; bottom-hole core obtained.

f. Total drilled depth: $514.8 \mathrm{~m}$.

g. Bit diameter below water level: $222.2 \mathrm{~mm}$.

h. Casing extending below water level: None (surface casing only, to a depth of $9.91 \mathrm{~m}$ ).

i. Description of access for measuring water levels, including tubes or piezometers: $61-\mathrm{mm}$ inside-diameter tubing that has a $3.7-\mathrm{m}-10 \mathrm{ng}$ well screen on the bottom; tubing and attached screen extend from land surface to a depth of $507.5 \mathrm{~m}$; saturated interval of borehole within tuffaceous beds of Calico Hills to Bullfrog Member of Crater Flat Tuff.

j. Description and altitude of reference point: Top of metal tag on well casing, 1,201.11 m (surveyed by U.S. Geological Survey, 1984).

$k$. Description and height of MP above reference point: Top of access tube, $0.314 \mathrm{~m}$.

1. Depth correction for measured water levels because of borehole deviation from vertical (the correction is subtracted from measured depth to obtain true depth): $0.327 \mathrm{~m}$, based on approximate depth to water of $469.7 \mathrm{~m}$.

3. History of instrumentation and water-level measurements, and comments:

The water-level measurements were made using a multiconductor-cable unit (logging van I-127410) from June 29, 1983, through April 11, 1985. Measurements were made using the 2,800-ft reference steel tape from June 13, 1985, through December 27, 1985, and for one measurement made March 21, 1988. The $2,600-\mathrm{ft}$ reeled steel tape was used from January 27, 1986, through January 9, 1989. Chain 非 was used from February 22, 1989, through December 27, 1989. 
4. Periodic measurements of water-level altitude in well USW WT-1:

[Method: S, 2,600-ft Reeled steel tape; R, 2,800-ft Reference steel tape; C, Chain 非]

Site ID: 364916116265601

Depth interval: 471-515 m (composite)

\begin{tabular}{cccccc}
\hline Date & $\begin{array}{c}\text { Water-1evel } \\
\text { altitude } \\
\text { (meters) }\end{array}$ & Method & Date & $\begin{array}{c}\text { Water-level } \\
\text { altitude } \\
\text { (meters) }\end{array}$ & Method \\
\hline $01 / 26 / 88$ & 730.38 & $\mathrm{~S}$ & $01 / 09 / 89$ & 730.37 & $\mathrm{~S}$ \\
$02 / 26 / 88$ & 730.39 & $\mathrm{~S}$ & $02 / 22 / 89$ & 730.40 & $\mathrm{C}$ \\
$03 / 21 / 88$ & 730.37 & $\mathrm{R}$ & $03 / 13 / 89$ & 730.42 & $\mathrm{C}$ \\
$04 / 25 / 88$ & 730.40 & $\mathrm{~S}$ & $-04 / 25 / 89$ & 730.41 & $\mathrm{C}$ \\
$05 / 23 / 88$ & 730.44 & $\mathrm{~S}$ & $05 / 24 / 89$ & 730.41 & $\mathrm{C}$ \\
$06 / 28 / 88$ & 730.42 & $\mathrm{~S}$ & $06 / 30 / 89$ & 730.42 & $\mathrm{C}$ \\
$07 / 11 / 88$ & 730.42 & $\mathrm{~S}$ & $07 / 19 / 89$ & 730.43 & $\mathrm{C}$ \\
$08 / 12 / 88$ & 730.40 & $\mathrm{~S}$ & $08 / 09 / 89$ & 730.40 & $\mathrm{C}$ \\
$09 / 14 / 88$ & 730.37 & $\mathrm{~S}$ & $10 / 02 / 89$ & 730.49 & $\mathrm{C}$ \\
$10 / 27 / 88$ & 730.42 & $\mathrm{~S}$ & $11 / 16 / 89$ & 730.43 & $\mathrm{C}$ \\
$12 / 20 / 88$ & 730.42 & $\mathrm{~S}$ & $12 / 27 / 89$ & 730.44 & $\mathrm{C}$ \\
\hline
\end{tabular}

5. Hydrograph of water-level altitude (plotted from data in section 4):

\section{USW WT-1}

Site ID: 364916116265601

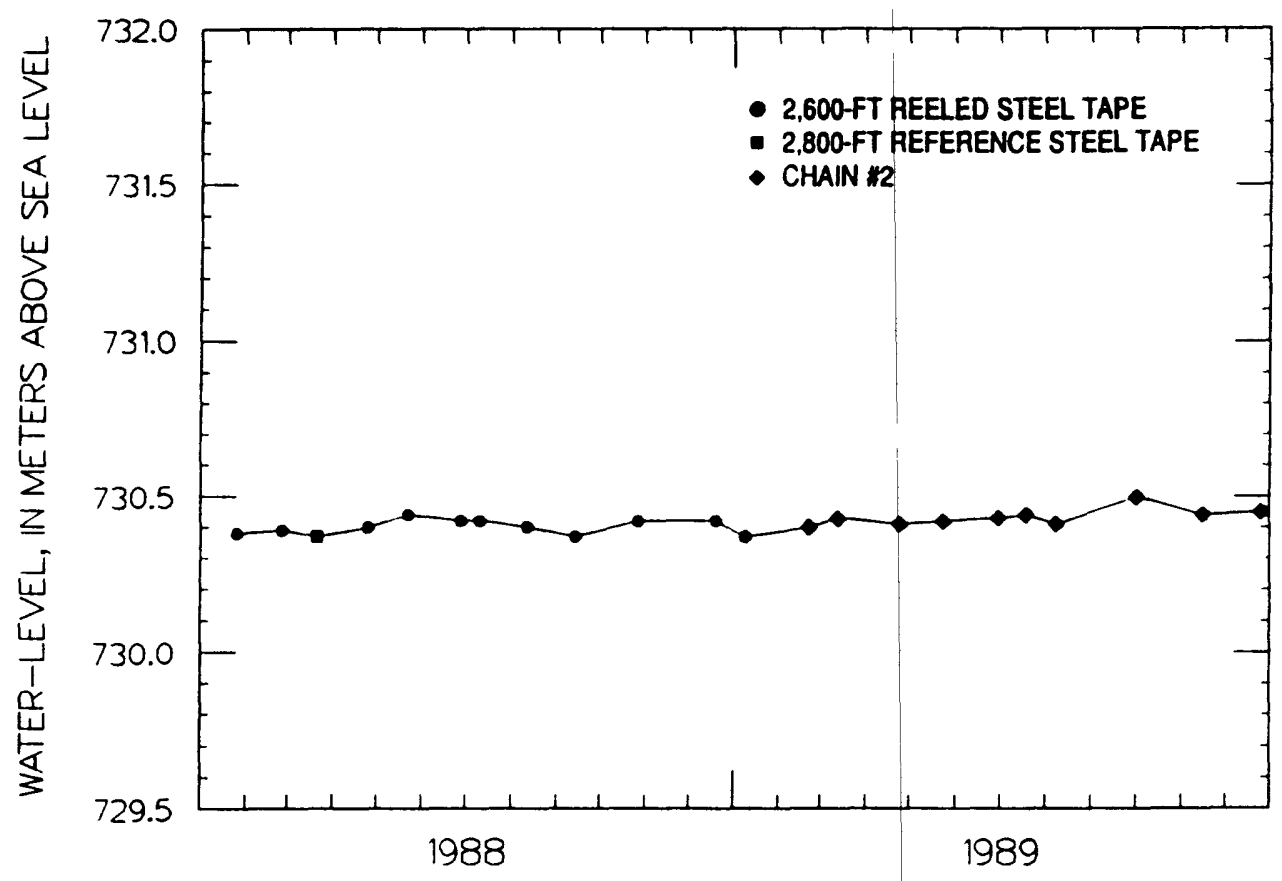


6. Maximum, minimum, and average water-level altitudes for well USW WT-1:

\begin{tabular}{|c|c|c|c|c|c|}
\hline \multirow{2}{*}{$\begin{array}{c}\text { Calendar } \\
\text { year }\end{array}$} & \multicolumn{3}{|c|}{ Water-level altitude (meters) } & \multirow{2}{*}{$\begin{array}{l}\text { Range } \\
\text { (meters) }\end{array}$} & \multirow{2}{*}{$\begin{array}{l}\text { Number of } \\
\text { measure } \\
\text { ments }\end{array}$} \\
\hline & Maximum & Minimum & Average & & \\
\hline${ }^{1} 1983$ & 730.30 & 730.05 & 730.19 & 0.25 & 10 \\
\hline 1984 & 730.20 & 729.91 & 730.09 & 0.29 & 21 \\
\hline 1985 & 730.50 & 729.98 & 730.19 & 0.52 & 10 \\
\hline 1986 & 730.39 & 730.22 & 730.32 & 0.17 & 16 \\
\hline 1987 & 730.40 & 730.29 & 730.35 & 0.11 & 14 \\
\hline 1988 & 730.44 & 730.37 & 730.40 & 0.07 & 11 \\
\hline 1989 & 730.49 & 730.37 & 730.42 & 0.12 & 11 \\
\hline
\end{tabular}

${ }^{1}$ June-December.

7. Bar graph of annual maximum, minimum, and average water-level altitudes (plotted from data in section 6):

USW WT-1

Site ID: 364916116265601

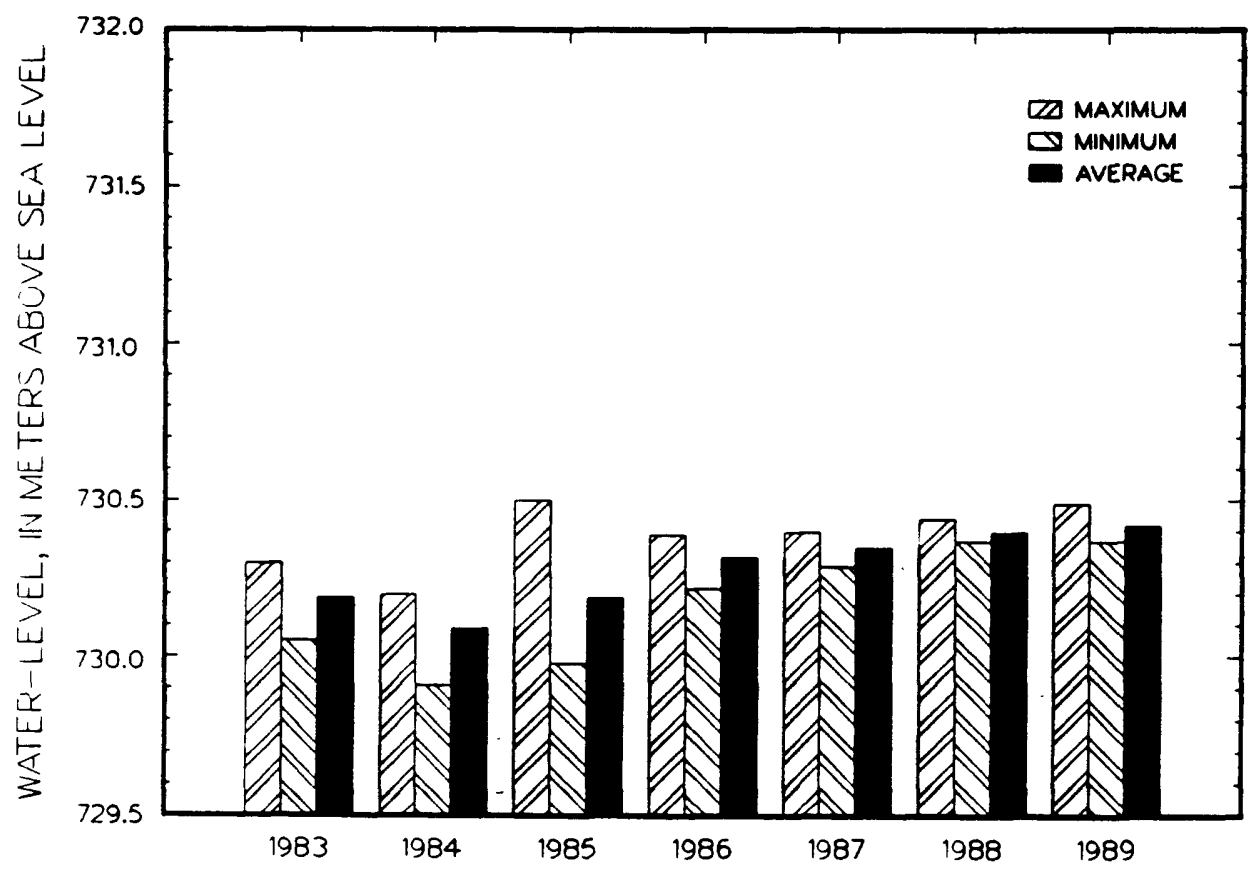


1. References or information sources: Robison (1984, 1986); Robison and others (1988); Holmes \& Narver, Inc. (written commun., 1986); Fenix \& Scisson, Inc. (1986a, 1987).

2. Well specifications:

a. Location:

Nevada State Central Zone Coordinates (m): N 227,379; E 174,768.

Latitude and longitude: $36^{\circ} 47^{\prime} 57^{\prime \prime} \mathrm{N}$.; $116^{\circ} 24^{\prime} 58^{\prime \prime} \mathrm{W}$.

Site ID: 364757116245801.

b. Land-surface altitude: 1,030.0 m (Robison, 1986; based on survey by U.S. Geological Survey, 1984).

c. Date drilling started: April 29, 1983

d. Date drilling completed: May 25, 1983.

e. Drilling method: Rotary, using rock bits and air-foam circulating medium; bottom-hole core obtained.

f. Total drilled depth: $348.1 \mathrm{~m}$.

g. Bit diameter below water level: $222.2 \mathrm{~mm}$.

h. Casing extending below water level: None (surface casing only, to a depth of $12.2 \mathrm{~m}$ ).

i. Description of access for measuring water levels, including tubes or piezometers: $61-\mathrm{mm}$ inside-diameter tubing that has a $3.7-\mathrm{m}-1$ ong well screen on the bottom; tubing and attached screen extend from land surface to a depth of $342.9 \mathrm{~m}$; saturated interval of borehole within Bullfrog Member of Crater Flat Tuff.

j. Description and altitude of reference point: Top of metal tag on well casing, 1,030.11 m (surveyed by U.S. Geological Survey, 1984).

k. Description and height of MP above reference point: Top of access tube, $0.155 \mathrm{~m}$.

1. Depth correction for measured water levels because of borehole deviation from vertical (the correction is subtracted from measured depth to obtain true depth): $0.271 \mathrm{~m}$, based on approximate depth to water of $299.9 \mathrm{~m}$.

3. History of instrumentation and water-level measurements, and comments:

The water-level measurements were made using a multiconductor-cable unit (logging van I-127410) from June 7, 1983, through March 22, 1985. From March 1985 through January 1989, the water level was monitored continuously using a downhole pressure transducer with a datalogger at the land surface. Waterlevel measurements were made on November 14, 1989, and December 21, 1989, with chain \#2.

4. Periodic measurements of water-level altitude in we11 UE-25 WT 非

[Method: C, Chain 非]

Site ID: 364757116245801

Depth interval: 301-348 m (composite)

Date

Water-level altitude (meters)

Method

$11 / 14 / 89$

729.76

$12 / 21 / 89$

729.70

C

C 
5. Maximum, minimum, and average water-level altitudes for well USW WT 非

\begin{tabular}{|c|c|c|c|c|c|}
\hline \multirow{2}{*}{$\begin{array}{c}\text { Calendar } \\
\text { year }\end{array}$} & \multicolumn{3}{|c|}{ Water-level altitude (meters) } & \multirow{2}{*}{$\begin{array}{l}\text { Range } \\
\text { (meters) }\end{array}$} & \multirow{2}{*}{$\begin{array}{c}\text { Number of } \\
\text { measure- } \\
\text { ments }\end{array}$} \\
\hline & Maximum & Minimum & Average & & \\
\hline $\begin{array}{r}{ }^{1} 1983 \\
1984 \\
{ }^{2} 1985 \\
{ }^{3} 1989\end{array}$ & $\begin{array}{l}729.76 \\
729.80 \\
729.55 \\
729.76\end{array}$ & $\begin{array}{l}729.52 \\
729.41 \\
729.51 \\
729.70\end{array}$ & $\begin{array}{l}729.64 \\
729.60 \\
729.52 \\
729.73\end{array}$ & $\begin{array}{l}0.24 \\
0.39 \\
0.04 \\
0.06\end{array}$ & $\begin{array}{r}11 \\
22 \\
4 \\
2\end{array}$ \\
\hline
\end{tabular}

${ }^{1}$ June-December.

2 January-March.

${ }^{3}$ November-December.

6. Bar graph of annual maximum, minimum, and average water-level altitudes (plotted from data in section 5):

UE-25 WT \#3

Site 1D: 364757116245801

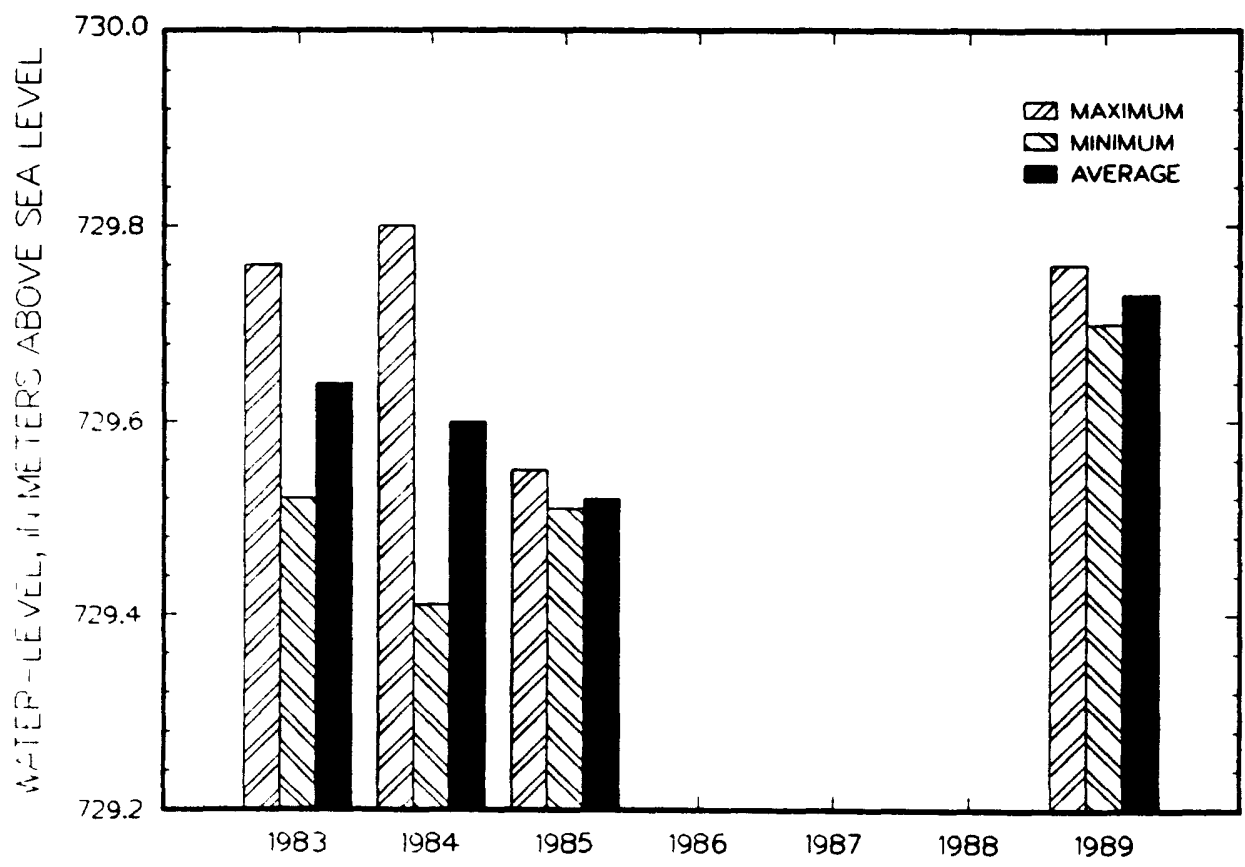


1. References or information sources: Robison (1984, 1986); Robison and others (1988); Holmes \& Narver, Inc. (written commun., 1986); Fenix \& Scisson, Inc. (1986a, 1987).

2. Well specifications:

a. Location:

Nevada State Central Zone Coordinates (m): N 234,242; E 173,139.

Latitude and longitude: 36 $51^{\prime} 40^{\prime \prime} \mathrm{N}$.; 116 $26^{\circ} 03^{\prime \prime} \mathrm{W}$.

Site ID: 365140116260301.

b. Land-surface altitude: 1,169.2 m (Robison, 1986; based on survey by U.S. Geological Survey, 1984).

c. Date drilling started: May 28, 1983.

d. Date drilling completed: June 6, 1983.

e. Drilling method: Rotary, using rock bits and air-foam circulating medium; bottom-hole core obtained.

f. Total drilled depth: $481.6 \mathrm{~m}$.

g. Bit diameter below water level: $222.2 \mathrm{~mm}$.

h. Casing extending below water level: None (surface casing only, to a depth of $14.6 \mathrm{~m}$ ).

i. Description of access for measuring water levels, including tubes or piezometers: $61-\mathrm{mm}$ inside-diameter tubing that has a $3.7-\mathrm{m}-1$ ong well screen on the bottom; tubing and attached screen extend from land surface to a depth of $477.6 \mathrm{~m}$; saturated interval of borehole within tuffaceous beds of Calico Hills.

j. Description and altitude of reference point: Top of metal tag on well casing, 1,169.21 m (surveyed by U.S. Geological Survey, 1984).

k. Description and height of MP above reference point: Top of access tube, $0.311 \mathrm{~m}$.

1. Depth correction for measured water levels because of borehole deviation from vertical (the correction is subtracted from measured depth to obtain true depth): $0.454 \mathrm{~m}$, based on approximate depth to water of $438.9 \mathrm{~m}$.

3. History of instrumentation and water-level measurements, and comments:

The water-level measurements were made using a multiconductor-cable unit (logging van I-127410) from June 8, 1983, through April 29, 1985. Measurements were made using the 2,800-ft reference steel tape from June 12, 1985, through December 6, 1985, and using the 2,600-ft reeled steel tape from January 29, 1986, through April 11, 1988. The multiconductor-cable unit housed in van I-133970 was used to make water-level measurements from April 18,1988 , to February 22, 1989. Chain 非 was used to make water-level measurements from March 22, 1989, through December 8, 1989.

From April 11 through 18, 1988, personnel from the Desert Research Institute pumped a total volume of about $3,000 \mathrm{I}$ of water from the well for the purpose of obtaining water samples. As a result, subsequent water-level measurements might reflect some residual effects from pumping until the saturated interval had sufficient time to recover. 
4. Periodic measurements of water-level altitude in well UE-25 WT \#4:

[Method: S, 2,600-ft Reeled steel tape; V, Multiconductor cable; C, Chain 非]

\begin{tabular}{|c|c|c|c|c|c|}
\hline \multirow[b]{2}{*}{ Date } & \multicolumn{2}{|c|}{$\begin{array}{r}\text { Site ID: } \\
\text { Depth interval: }\end{array}$} & \multicolumn{2}{|c|}{$\begin{array}{l}365140116260301 \\
439-482 \mathrm{~m} \text { (composite) }\end{array}$} & \multirow[b]{2}{*}{ Method } \\
\hline & $\begin{array}{l}\text { Water-level } \\
\text { altitude } \\
\text { (meters) }\end{array}$ & Method & Date & $\begin{array}{l}\text { Water-level } \\
\text { altitude } \\
\text { (meters) }\end{array}$ & \\
\hline $\begin{array}{l}01 / 27 / 88 \\
02 / 17 / 88 \\
04 / 11 / 88 \\
04 / 18 / 88\end{array}$ & $\begin{array}{l}730.82 \\
730.77 \\
730.83 \\
730.65\end{array}$ & $\begin{array}{l}\mathrm{S} \\
\mathrm{S} \\
\mathrm{S} \\
\mathrm{V}\end{array}$ & $\begin{array}{l}02 / 22 / 89 \\
03 / 22 / 89 \\
04 / 25 / 89 \\
05 / 24 / 89\end{array}$ & $\begin{array}{l}730.78 \\
730.87 \\
730.83 \\
730.83\end{array}$ & $\begin{array}{l}\mathrm{V} \\
\mathrm{C} \\
\mathrm{C} \\
\mathrm{C}\end{array}$ \\
\hline $\begin{array}{l}04 / 19 / 88 \\
05 / 24 / 88 \\
06 / 29 / 88 \\
07 / 14 / 88\end{array}$ & $\begin{array}{l}730.65 \\
730.66 \\
730.61 \\
730.62\end{array}$ & $\begin{array}{l}\mathrm{V} \\
\mathrm{V} \\
\mathrm{V} \\
\mathrm{V}\end{array}$ & $\begin{array}{l}06 / 30 / 89 \\
07 / 13 / 89 \\
07 / 24 / 89 \\
08 / 09 / 89\end{array}$ & $\begin{array}{l}730.85 \\
730.82 \\
730.84 \\
730.86\end{array}$ & $\begin{array}{l}\mathrm{C} \\
\mathrm{C} \\
\mathrm{C} \\
\mathrm{C}\end{array}$ \\
\hline $\begin{array}{l}09 / 22 / 88 \\
10 / 28 / 88 \\
12 / 20 / 88 \\
01 / 09 / 89\end{array}$ & $\begin{array}{l}730.61 \\
730.63 \\
730.81 \\
730.72\end{array}$ & $\begin{array}{l}\text { V } \\
V \\
V \\
V\end{array}$ & $\begin{array}{l}10 / 03 / 89 \\
11 / 22 / 89 \\
12 / 08 / 89\end{array}$ & $\begin{array}{l}730.88 \\
730.87 \\
730.83\end{array}$ & $\begin{array}{l}C \\
C \\
C\end{array}$ \\
\hline
\end{tabular}

5. Hydrograph of water-level altitude (plotted from data in section 4):

\section{UE-25 WT\#4}

Site ID: 365140116260301

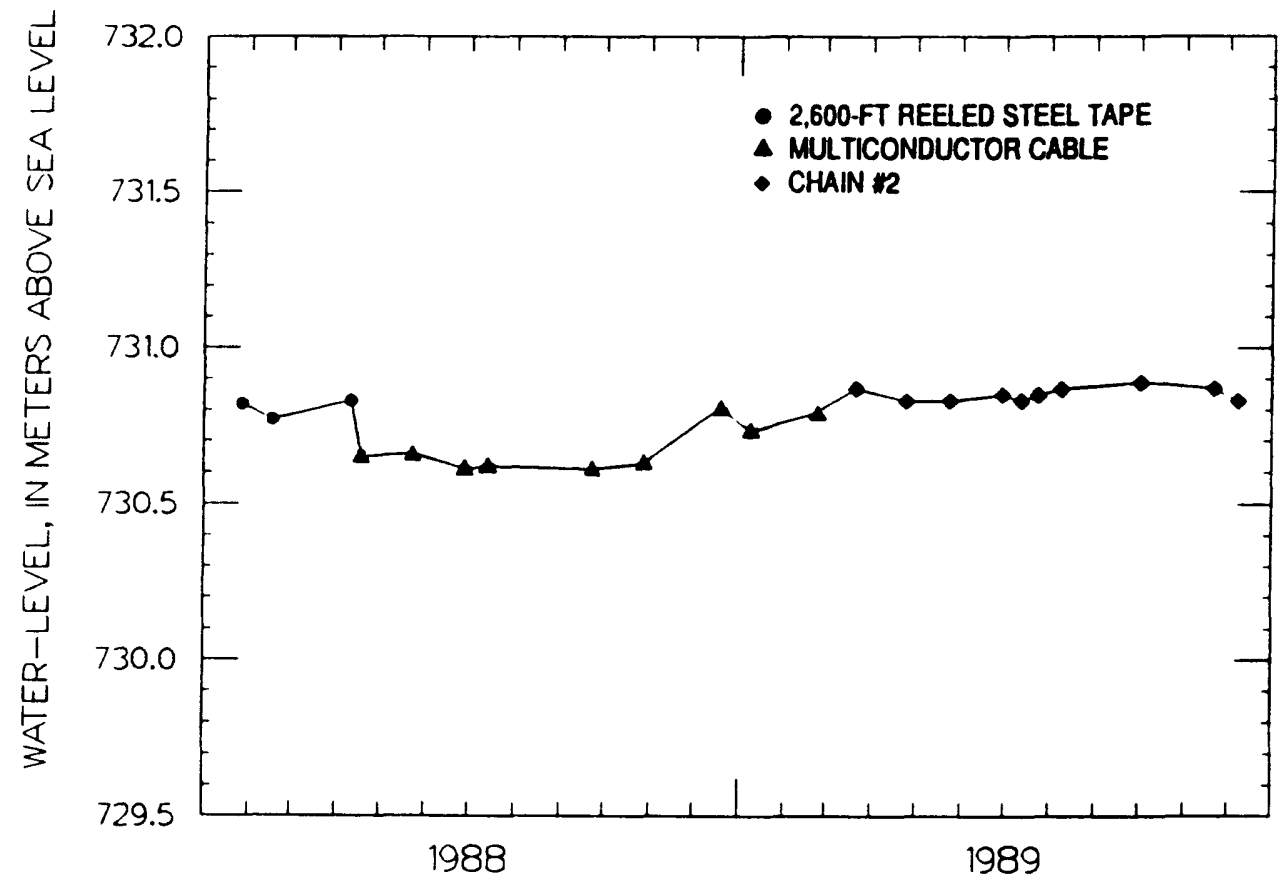


6. Maximum, minimum, and average water-level altitudes for well UE-25 WT 非:

\begin{tabular}{cccccc}
\hline $\begin{array}{c}\text { Calendar } \\
\text { year }\end{array}$ & \multicolumn{2}{c}{ Water-level altitude (meters) } & $\begin{array}{c}\text { Range } \\
\text { (meters) }\end{array}$ & $\begin{array}{c}\text { Number of } \\
\text { measure- } \\
\text { ments }\end{array}$ \\
\cline { 2 - 4 }${ }^{1} 1983$ & 730.69 & 730.49 & 730.60 & 0.20 & 14 \\
1984 & 730.59 & 730.33 & 730.48 & 0.26 & 21 \\
1985 & 730.72 & 730.28 & 730.55 & 0.44 & 14 \\
1986 & 730.79 & 730.69 & 730.75 & 0.10 & 14 \\
1987 & 730.85 & 730.69 & 730.78 & 0.16 & 14 \\
1988 & 730.83 & 730.61 & 730.70 & 0.22 & 11 \\
1989 & 730.88 & 730.72 & 730.83 & 0.16 & 12 \\
\hline
\end{tabular}

\section{${ }^{1}$ June-December.}

7. Bar graph of annual maximum, minimum, and average water-level altitudes (plotted from data in section 6):

\section{UE-25 WT \#4}

Site ID: 365140116260301

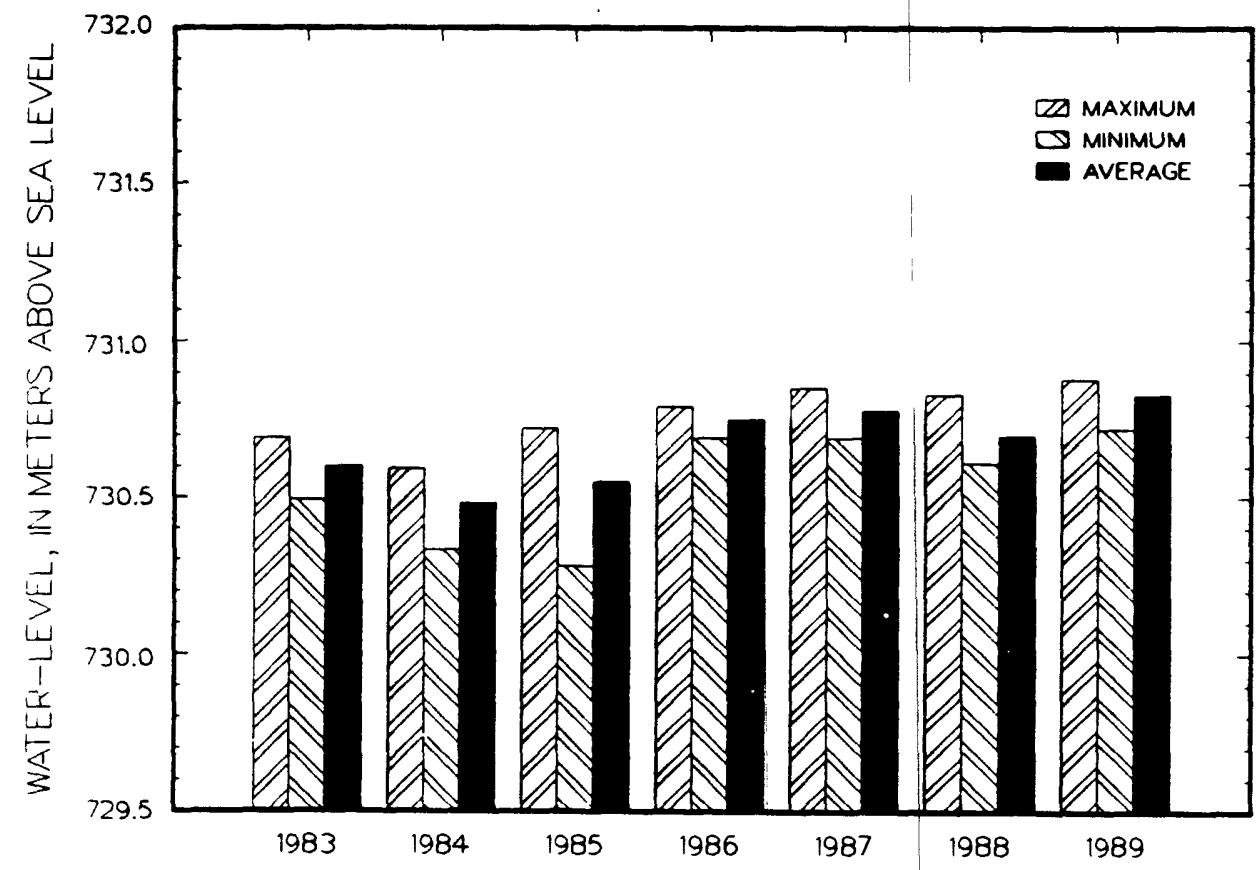




\section{Well USW WT-7}

1. References or information sources: Robison (1984, 1986); Robison and others (1988); Holmes \& Narver, Inc. (written commun., 1986); Fenix \& Scisson, Inc. (1986a, 1987).

2. Well specifications:

a. Location:

Nevada State Central Zone Coordinates (m): N 230,298; E 168,826.

Latitude and longitude: $36^{\circ} 49^{\prime} 33^{\prime \prime} \mathrm{N}$.; $116^{\circ} 28^{\prime} 57^{\prime \prime} \mathrm{W}$.

Site ID: 364933116285701.

b. Land-surface altitude: 1,196.9 m (Robison, 1986; based on survey by U.S. Geological Survey, 1984).

c. Date drilling started: July $19,1983$.

d. Date drilling completed: July 26, 1983.

e. Drilling method: Rotary, using rock bits and air-foam circulating medium; bottom-hole core obtained.

f. Total drilled depth: $490.7 \mathrm{~m}$.

g. Bit diameter below water level: $222.2 \mathrm{~mm}$.

h. Casing extending below water level: None (surface casing only, to a depth of $15.8 \mathrm{~m}$ ).

i. Description of access for measuring water levels, including tubes or piezometers: $61-\mathrm{mm}$ inside-diameter tubing that has a $3.7-\mathrm{m}-$ long well screen on the bottom; tubing and attached screen extend from land surface to a depth of $481.3 \mathrm{~m}$; saturated interval of borehole within Topopah Spring Member of Paintbrush Tuff to Prow Pass Member of Crater Flat Tuff.

j. Description and altitude of reference point: Top of metal tag on well casing, 1,196.88 $\mathrm{m}$ (surveyed by U.S. Geological Survey, 1984).

k. Description and height of MP above reference point: Top of access tube, $0.302 \mathrm{~m}$.

1. Depth correction for measured water levels because of borehole deviation from vertical (the correction is subtracted from measured depth to obtain true depth): $0.034 \mathrm{~m}$, based on approximate depth to water of $420.9 \mathrm{~m}$.

3. History of instrumentation and water-level measurements, and comments:

The water-level measurements were made using a multiconductor cable (logging van I-127410) from August 30, 1983, through April 16, 1985. Measurements were made using the 2,800-ft reference steel tape from June 21, 1985, through December 28, 1985, and using the 2,600-ft reeled steel tape from January 1, 1986, through May 27, 1987. The multiconductor cable unit, which is housed in van I-133970, was used to make water-level measurements from May 16, 1988, to February 16, 1989. From March 23, 1989, through December 21, 1989 , chain 非 2 was used to measure water levels.

On June 6, 1988, personnel with the Desert Research Institute pumped about $760 \mathrm{~L}$ of water from the well for the purpose of obtaining water samples. As a result, subsequent water-level measurements might reflect some residual effects from pumping until the saturated interval had sufficient time to recover. 
4. Periodic measurements of water-level altitude in well USW WT-7:

[Method: V, Multiconductor cable; C, Chain \#2]

\begin{tabular}{cccccc}
\hline \multicolumn{5}{c}{$\begin{array}{c}\text { Site ID: } \\
\text { Depth interva1: }\end{array}$} & $\begin{array}{l}364933116285701 \\
421-491 \mathrm{~m} \text { (composite) }\end{array}$ \\
\hline Date & $\begin{array}{c}\text { Water-level } \\
\text { altitude } \\
\text { (meters) }\end{array}$ & Method & Date & $\begin{array}{c}\text { Water-level } \\
\text { altitude } \\
\text { (meters) }\end{array}$ & Method \\
\hline $05 / 16 / 88$ & 775.72 & $\mathrm{~V}$ & $01 / 19 / 89$ & 775.87 & $\mathrm{~V}$ \\
$06 / 03 / 88$ & 775.67 & $\mathrm{~V}$ & $02 / 16 / 89$ & 775.79 & $\mathrm{~V}$ \\
$06 / 13 / 88$ & 775.62 & $\mathrm{~V}$ & $03 / 23 / 89$ & 775.90 & $\mathrm{C}$ \\
$06 / 23 / 88$ & 775.66 & $\mathrm{~V}$ & $04 / 21 / 89$ & 775.87 & $\mathrm{C}$ \\
$07 / 08 / 88$ & 775.57 & $\mathrm{~V}$ & $05 / 18 / 89$ & 775.86 & $\mathrm{C}$ \\
$08 / 17 / 88$ & 775.69 & $\mathrm{~V}$ & $07 / 18 / 89$ & 775.84 & $\mathrm{C}$ \\
$09 / 08 / 88$ & 775.73 & $\mathrm{~V}$ & $10 / 04 / 89$ & 775.84 & $\mathrm{C}$ \\
$10 / 06 / 88$ & 775.70 & $\mathrm{~V}$ & $11 / 28 / 89$ & 775.71 & $\mathrm{C}$ \\
$11 / 17 / 88$ & 775.73 & $\mathrm{~V}$ & $12 / 21 / 89$ & 775.81 & \\
$12 / 21 / 88$ & 775.88 & $\mathrm{~V}$ & & & \\
\hline
\end{tabular}

5. Hydrograph of water-level altitude (plotted from data in section 4):

\section{USW WT-7}

Site ID: 364933116285701

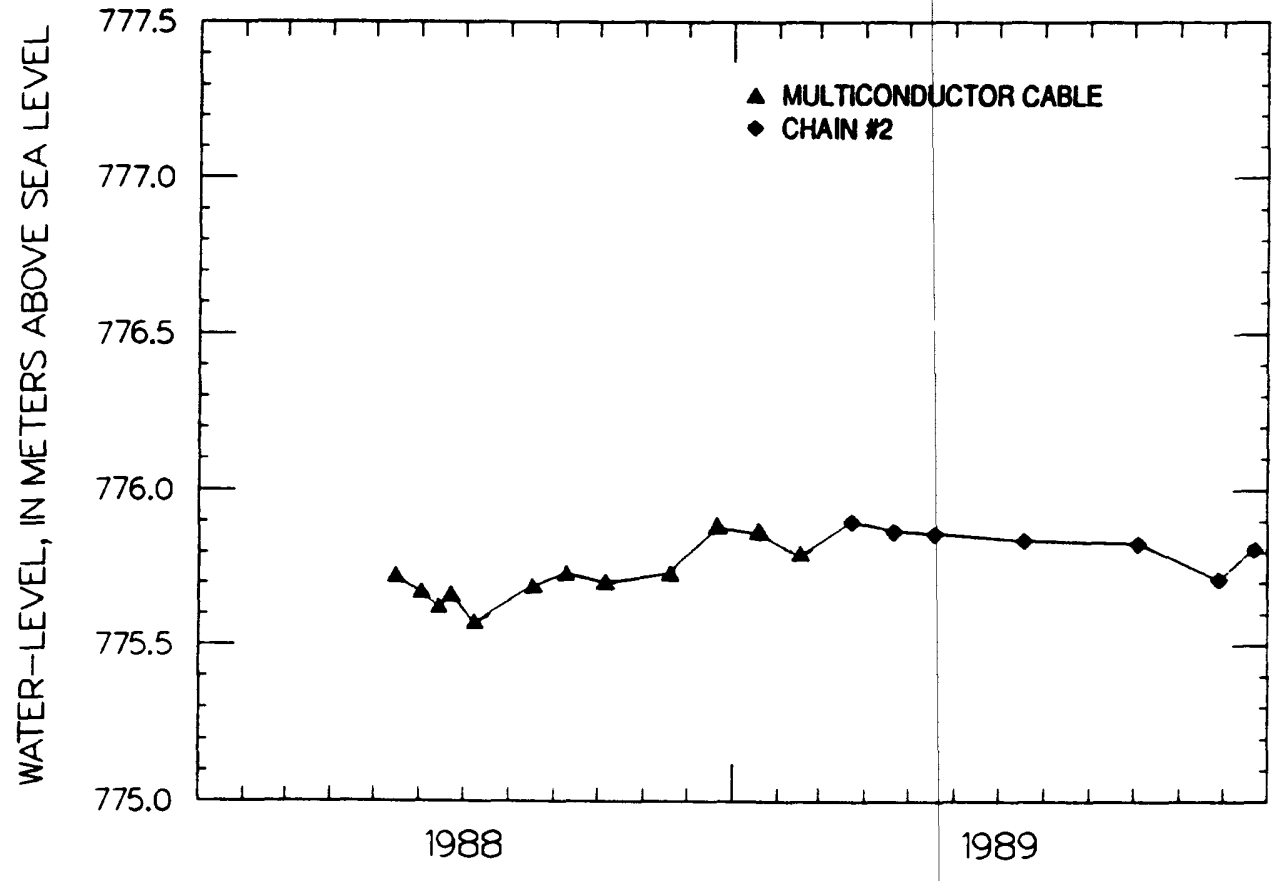


6. Maximum, minimum, and average water-level altitudes for well USW WT-7:

\begin{tabular}{|c|c|c|c|c|c|}
\hline \multirow{2}{*}{$\begin{array}{l}\text { Calendar } \\
\text { year }\end{array}$} & \multicolumn{3}{|c|}{ Water-level altitude (meters) } & \multirow{2}{*}{$\begin{array}{l}\text { Range } \\
\text { (meters) }\end{array}$} & \multirow{2}{*}{$\begin{array}{c}\text { Number of } \\
\text { measure- } \\
\text { ments }\end{array}$} \\
\hline & Maximum & Minimum & Average & & \\
\hline${ }^{1} 1983$ & 775.82 & 775.70 & 775.74 & 0.12 & 10 \\
\hline 1984 & 775.73 & 775.52 & 775.64 & 0.21 & 19 \\
\hline 1985 & 775.87 & 775.47 & 775.73 & 0.40 & 16 \\
\hline 1986 & 775.87 & 775.65 & 775.78 & 0.22 & 11 \\
\hline 21987 & 775.88 & 775.71 & 775.80 & 0.17 & 5 \\
\hline${ }^{3} 1988$ & 775.88 & 775.57 & 775.70 & 0.31 & 10 \\
\hline 1989 & 775.90 & 775.71 & 775.83 & 0.19 & 9 \\
\hline
\end{tabular}

${ }^{1}$ August-December.

2 January-May.

${ }^{3}$ May-December.

7. Bar graph of annual maximum, minimum, and average water-level altitudes (plotted from data in section 6):

\section{USW WT-7}

Site ID: 364933116285701

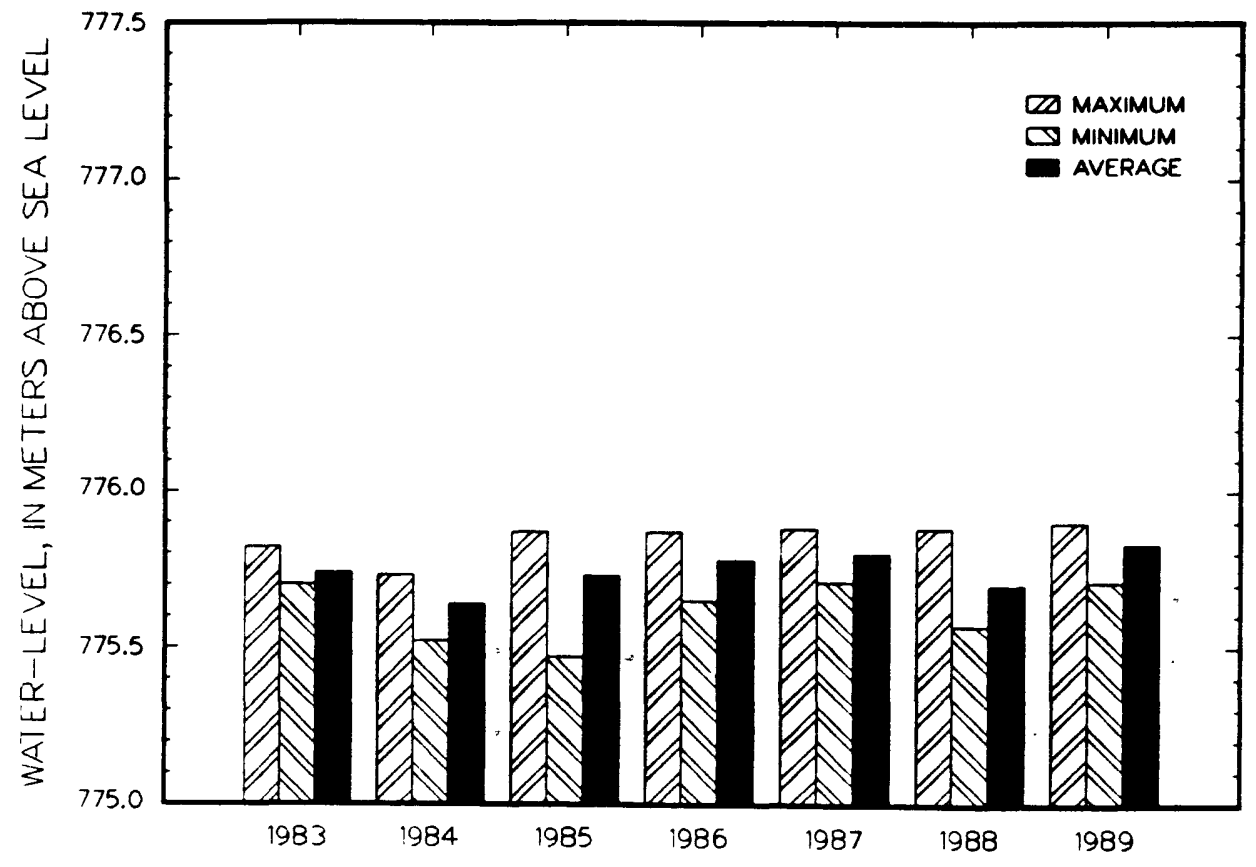


We11 USW WT-10

1. References or information sources: Robison (1984, 1986); Robison and others (1988); Holmes \& Narver, Inc. (written commun., 1986); Fenix \& Scisson, Inc. (1986a, 1987).

2. Well specifications:

a. Location:

Nevada State Central Zone Coordinates (m): N 228,225; E 168,646. Latitude and longitude: $36^{\circ} 48^{\prime} 25^{\prime \prime} \mathrm{N} . ; 116^{\circ} 29^{\prime} 05^{\prime \prime} \mathrm{W}$.

Site ID: 364825116290501.

b. Land-surface altitude: 1,123.4 m (Robison, 1986; based on survey by U.S. Geological Survey, 1984).

c. Date drilling started: July $26,1983$.

d. Date drilling completed: August 2, 1983.

e. Drilling method: Rotary, using rock bits and air-foam circulating medium; bottom-hole core obtained:-

f. Total drilled depth: $430.7 \mathrm{~m}$.

8. Bit diameter below water level: $222.2 \mathrm{~mm}$.

h. Casing extending below water level: None (surface casing only, to a depth of $34.7 \mathrm{~m}$ ).

i. Description of access for measuring water levels, including tubes or piezometers: $61-\mathrm{mm}$ inside-diameter tubing that has a $3.7-\mathrm{m}-$ long well screen on the bottom; tubing and attached screen extend from land surface to a depth of $402.6 \mathrm{~m}$; saturated interval of borehole within Topopah Spring Member of Paintbrush Tuff.

j. Description and altitude of reference point: Top of metal tag on well casing, $1,123.40 \mathrm{~m}$ (surveyed by U.S. Geological Survey, 1984).

k. Description and height of MP above reference point: Top of access tube, $0.314 \mathrm{~m}$.

1. Depth correction for measured water levels because of borehole deviation from vertical (the correction is subtracted from measured depth to obtain true depth): $0.030 \mathrm{~m}$, based on approximate depth to water of $348.1 \mathrm{~m}$.

3. History of instrumentation and water-level measurements, and comments:

The water-level measurements were made using a multiconductor-cable unit (logging van I-127410) from August 30, 1983, through April 16, 1985. Measurements were made using the 2,800-ft reference steel tape from June 21, 1985, through December 13, 1985. Measurements thereafter were made using the 2,600ft reeled steel tape, except that the measurement on December 16, 1987, was made using the 2,800-ft reference steel tape, and those made August 17, 1988, and September 8,1988 , were made using the multiconductor cable unit housed in van I-133970. Measurements made during 1989 were made with chain 非.

From May 9 through 16, 1988, personnel from the Desert Research Institute pumped about $12,000 \mathrm{~L}$ of water from the well for the purpose of obtaining water samples. The water-level change of approximately $.4 \mathrm{~m}$ measured on April 5 and May 9, 1988 occurred befored pumping. Subsequent water-level measurements might reflect some residual effects from pumping until the saturated interval had sufficient time to recover. 
4. Periodic measurements of water-level altitude in well USW WT-10:

[Method: S, 2,600-ft Reeled steel tape; V, Multiconductor cable; C, Chain \#2]

\begin{tabular}{|c|c|c|c|c|c|c|}
\hline \multirow[b]{2}{*}{ Date } & \multicolumn{2}{|c|}{$\begin{array}{r}\text { Site ID: } \\
\text { Depth interval: }\end{array}$} & \multicolumn{3}{|c|}{$\begin{array}{l}364825116290501 \\
348-431 \mathrm{~m} \text { (composite) }\end{array}$} & \multirow[b]{2}{*}{ Method } \\
\hline & $\begin{array}{l}\text { Water-level } \\
\text { altitude } \\
\text { (meters) }\end{array}$ & Method & & Date & $\begin{array}{l}\text { Water-level } \\
\text { altitude } \\
\text { (meters) }\end{array}$ & \\
\hline $\begin{array}{l}01 / 22 / 88 \\
02 / 24 / 88 \\
03 / 07 / 88 \\
04 / 05 / 88\end{array}$ & $\begin{array}{l}775.89 \\
776.00 \\
775.96 \\
775.63\end{array}$ & $\begin{array}{l}\mathrm{S} \\
\mathrm{S} \\
\mathrm{S} \\
\mathrm{S}\end{array}$ & & $\begin{array}{l}11 / 17 / 88 \\
12 / 21 / 88 \\
01 / 19 / 89 \\
02 / 16 / 89\end{array}$ & $\begin{array}{l}776.06 \\
776.03 \\
776.00 \\
775.95\end{array}$ & $\begin{array}{l}S \\
S \\
C \\
C\end{array}$ \\
\hline $\begin{array}{l}05 / 09 / 88 \\
05 / 17 / 88 \\
05 / 18 / 88 \\
06 / 23 / 88\end{array}$ & $\begin{array}{l}775.63 \\
776.04 \\
775.99 \\
775.99\end{array}$ & $\begin{array}{l}S \\
S \\
S \\
S\end{array}$ & -- & $\begin{array}{l}03 / 23 / 89 \\
04 / 21 / 89 \\
05 / 18 / 89 \\
07 / 18 / 89\end{array}$ & $\begin{array}{l}776.04 \\
776.04 \\
775.99 \\
775.99\end{array}$ & $\begin{array}{l}\mathrm{C} \\
\mathrm{C} \\
\mathrm{C} \\
\mathrm{C}\end{array}$ \\
\hline $\begin{array}{l}07 / 08 / 88 \\
08 / 17 / 88 \\
09 / 08 / 88 \\
10 / 06 / 88\end{array}$ & $\begin{array}{l}775.99 \\
775.79 \\
775.85 \\
776.01\end{array}$ & $\begin{array}{l}S \\
V \\
V \\
S\end{array}$ & & $\begin{array}{l}10 / 04 / 89 \\
11 / 28 / 89 \\
12 / 21 / 89\end{array}$ & $\begin{array}{l}775.97 \\
775.88 \\
775.96\end{array}$ & $\begin{array}{l}c \\
C \\
C\end{array}$ \\
\hline
\end{tabular}

5. Hydrograph of water-level altitude (plotted from data in section 4):

\section{USW WT-10}

Site ID: 364825116290501

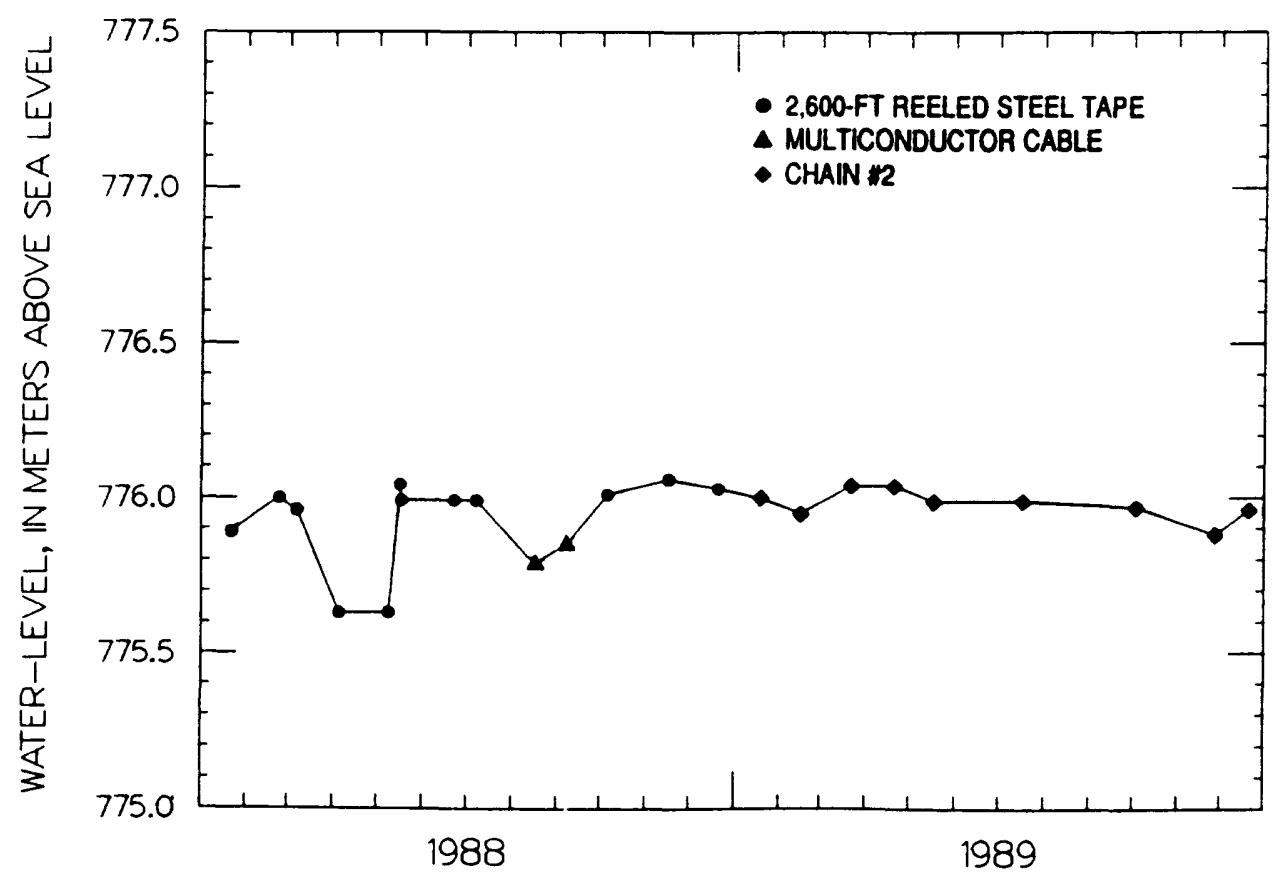


6. Maximum, minimum, and average water-level altitudes for well USW WT-10:

\begin{tabular}{|c|c|c|c|c|c|}
\hline \multirow{2}{*}{$\begin{array}{c}\text { Calendar } \\
\text { year }\end{array}$} & \multicolumn{3}{|c|}{ Water-level altitude (meters) } & \multirow{2}{*}{$\begin{array}{l}\text { Range } \\
\text { (meters) }\end{array}$} & \multirow{2}{*}{$\begin{array}{c}\text { Number of } \\
\text { measure- } \\
\text { ments }\end{array}$} \\
\hline & Maximum & Minimum & Average & & \\
\hline $\begin{array}{r}{ }^{1} 1983 \\
1984 \\
1985 \\
1986 \\
1987 \\
1988 \\
1989\end{array}$ & $\begin{array}{l}776.03 \\
776.07 \\
776.15 \\
775.99 \\
776.05 \\
776.06 \\
776.04\end{array}$ & $\begin{array}{l}775.74 \\
775.71 \\
775.55 \\
775.84 \\
775.63 \\
775.63 \\
775.88\end{array}$ & $\begin{array}{l}775.90 \\
775.83 \\
775.90 \\
775.93 \\
775.93 \\
775.92 \\
775.98\end{array}$ & $\begin{array}{l}0.29 \\
0.36 \\
0.60 \\
0.15 \\
0.42 \\
0.43 \\
0.16\end{array}$ & $\begin{array}{r}10 \\
19 \\
17 \\
11 \\
14 \\
14 \\
9\end{array}$ \\
\hline
\end{tabular}

${ }^{1}$ August-December.

7. Bar graph of annual maximum, minimum, and average water-level altitudes (plotted from data in section 6):

USW WT-10

Site ID: 364825116290501

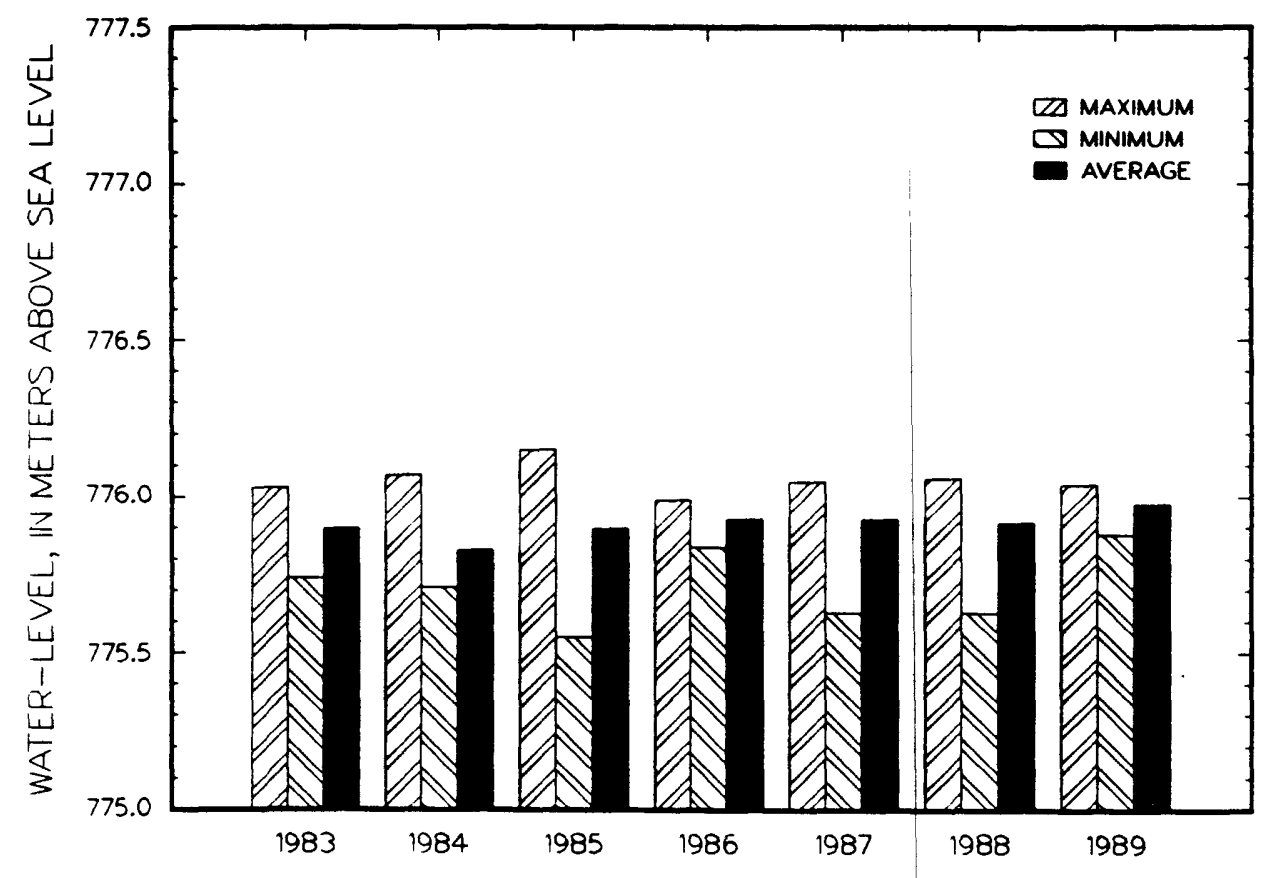




\section{Well UE-25 WT 非12}

1. References or information sources: Robison (1984, 1986); Robison and others (1988); Holmes \& Narver, Inc. (written commun., 1986); Fenix \& Scisson, Inc. (1986a, 1987).

2. Well specifications:

a. Location:

Nevada State Central Zone Coordinates (m): N 225,468; E 172,825. Latitude and longitude: $36^{\circ} 46^{\prime} 56^{\prime \prime}$ N.; $116^{\circ} 26^{\prime} 16^{\prime \prime} \mathrm{W}$.

Site ID: 364656116261601.

b. Land-surface altitude: 1,074.7 m (Robison, 1986; bașed on survey by U.S. Geological Survey, 1984).

c. Date drilling started: August 11, 1983.

d. Date drilling completed: August 16, 1983.

e. Drilling method: Rotary, using rock bits and air-foam circulating medium; bottom-hole core obtained.

f. Total drilled depth: $398.7 \mathrm{~m}$.

g. Bit diameter below water level: $222.2 \mathrm{~mm}$.

h. Casing extending below water level: None (surface casing only, to a depth of $21.3 \mathrm{~m}$ ).

i. Description of access for measuring water levels, including tubes or piezometers: $61-\mathrm{mm}$ inside-diameter tubing that has a $3.7-\mathrm{m}-$ long well screen on the bottom; tubing and attached screen extend from land surface to a depth of $388.9 \mathrm{~m}$; saturated interval of borehole within Topopah Spring Member of Paintbrush Tuff and tuffaceous beds of Calico Hills.

j. Description and altitude of reference point: Top of metal tag on well casing, 1,074.74 m (surveyed by U.S. Geological Survey, 1984).

k. Description and height of MP above reference point: Top of access tube, $0.305 \mathrm{~m}$.

1. Depth correction for measured water levels because of borehole deviation from vertical (the correction is subtracted from measured depth to obtain true depth): $0.182 \mathrm{~m}$, based on approximate depth to water of $345.0 \mathrm{~m}$.

3. History of instrumentation and water-level measurements, and comments:

The water-level measurements were made using a multiconductor-cable unit (logging van I-127410) from September 1, 1983, through April 10, 1985. Measurements were made using the $2,800-\mathrm{ft}$ reference steel tape from July 16 , 1985, through December 6, 1985, and using the 2,600-ft reeled steel tape from January 29, 1986, through January 9, 1989. Chain \#2 was used for water-level measurements from February 22, 1989, through December 20, 1989.

From April 25 to May 2, 1988, personnel from the Desert Research Institute pumped a total volume of about $9,500 \mathrm{~L}$ of water from the well for the purpose of obtaining water samples. As a result, subsequent water-level measurements might reflect some residual effects from pumping until the saturated interval had sufficient time to recover. 
4. Periodic measurements of water-level altitude in well UE-25 WT 非12:

[Method: S, 2,600-ft Reeled steel tape; C, Chain 非]

Site ID: 364656116261601

Depth interval: $345-399 \mathrm{~m}$ (composite)

\begin{tabular}{cccccc}
\hline Date & $\begin{array}{c}\text { Water-level } \\
\text { altitude } \\
\text { (meters) }\end{array}$ & Method & Date & $\begin{array}{c}\text { Water-1evel } \\
\text { altitude } \\
\text { (meters) }\end{array}$ & Method \\
\hline $01 / 28 / 88$ & 729.52 & $\mathrm{~S}$ & $12 / 23 / 88$ & 729.48 & $\mathrm{~S}$ \\
$02 / 26 / 88$ & 729.53 & $\mathrm{~S}$ & $01 / 09 / 89$ & 729.47 & $\mathrm{~S}$ \\
$04 / 25 / 88$ & 729.51 & $\mathrm{~S}$ & $02 / 22 / 89$ & 729.47 & $\mathrm{C}$ \\
$05 / 02 / 88$ & 729.45 & $\mathrm{~S}$ & $03 / 13 / 89$ & 729.53 & $\mathrm{C}$ \\
$05 / 03 / 88$ & 729.55 & $\mathrm{~S}$ & $04 / 26 / 89$ & 729.48 & $\mathrm{C}$ \\
$05 / 25 / 88$ & 729.51 & $\mathrm{~S}$ & $05 / 30 / 89$ & 729.49 & $\mathrm{C}$ \\
$06 / 27 / 88$ & 729.52 & $\mathrm{~S}$ & $07 / 21 / 89$ & 729.52 & $\mathrm{C}$ \\
$07 / 15 / 88$ & 729.53 & $\mathrm{~S}$ & $08 / 11 / 89$ & 729.49 & $\mathrm{C}$ \\
$08 / 12 / 88$ & 729.57 & $\mathrm{~S}$ & $10 / 05 / 89$ & 729.48 & $\mathrm{C}$ \\
$09 / 23 / 88$ & 729.51 & $\mathrm{~S}$ & $11 / 21 / 89$ & 729.53 & $\mathrm{C}$ \\
$10 / 27 / 88$ & 729.55 & $\mathrm{~S}$ & $12 / 20 / 89$ & 729.47 & \\
\hline
\end{tabular}

5. Hydrograph of water-level altitude (plotted from data in section 4):

\section{UE-25 WT \#12}

Site ID: 364656116261601

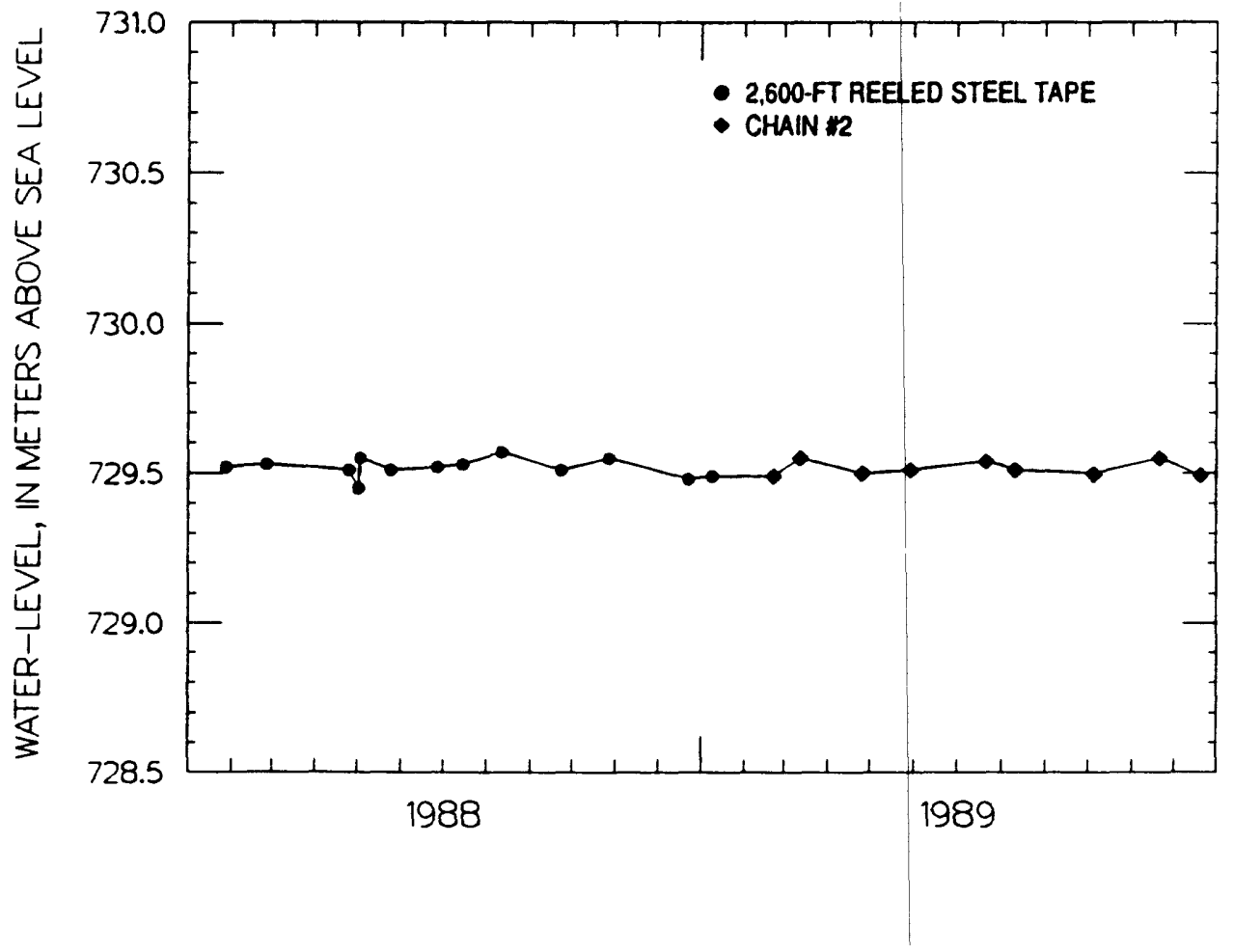


6. Maximum, minimum, and average water-level altitudes for well UE-25 WT 非12:

\begin{tabular}{|c|c|c|c|c|c|}
\hline \multirow{2}{*}{$\begin{array}{c}\text { Calendar } \\
\text { year }\end{array}$} & \multicolumn{3}{|c|}{ Water-level altitude (meters) } & \multirow{2}{*}{$\begin{array}{c}\text { Range } \\
\text { (meters) }\end{array}$} & \multirow{2}{*}{$\begin{array}{l}\text { Number of } \\
\text { measure- } \\
\text { ments }\end{array}$} \\
\hline & Maximum & Minimum & Average & & \\
\hline${ }^{1} 1983$ & 729.61 & 729.30 & 729.42 & 0.31 & 9 \\
\hline 1984 & 729.50 & 729.18 & 729.34 & 0.32 & 15 \\
\hline 1985 & 729.49 & 729.11 & 729.33 & 0.38 & 12 \\
\hline 1986 & 729.51 & 729.40 & 729.45 & 0.11 & 14 \\
\hline 1987 & 729.53 & 729.46 & 729.50 & 0.07 & 11 \\
\hline 1988 & 729.57 & 729.45 & 729.52 & 0.12 & 12 \\
\hline 1989 & 729.53 & 729.47 & 729.49 & 0.06 & 10 \\
\hline
\end{tabular}

${ }^{1}$ September-December.

7. Bar graph of annual maximum, minimum, and average water-level altitudes (plotted from data in section 6):

UE-25 WT \#12

Site 10: 364656116261601

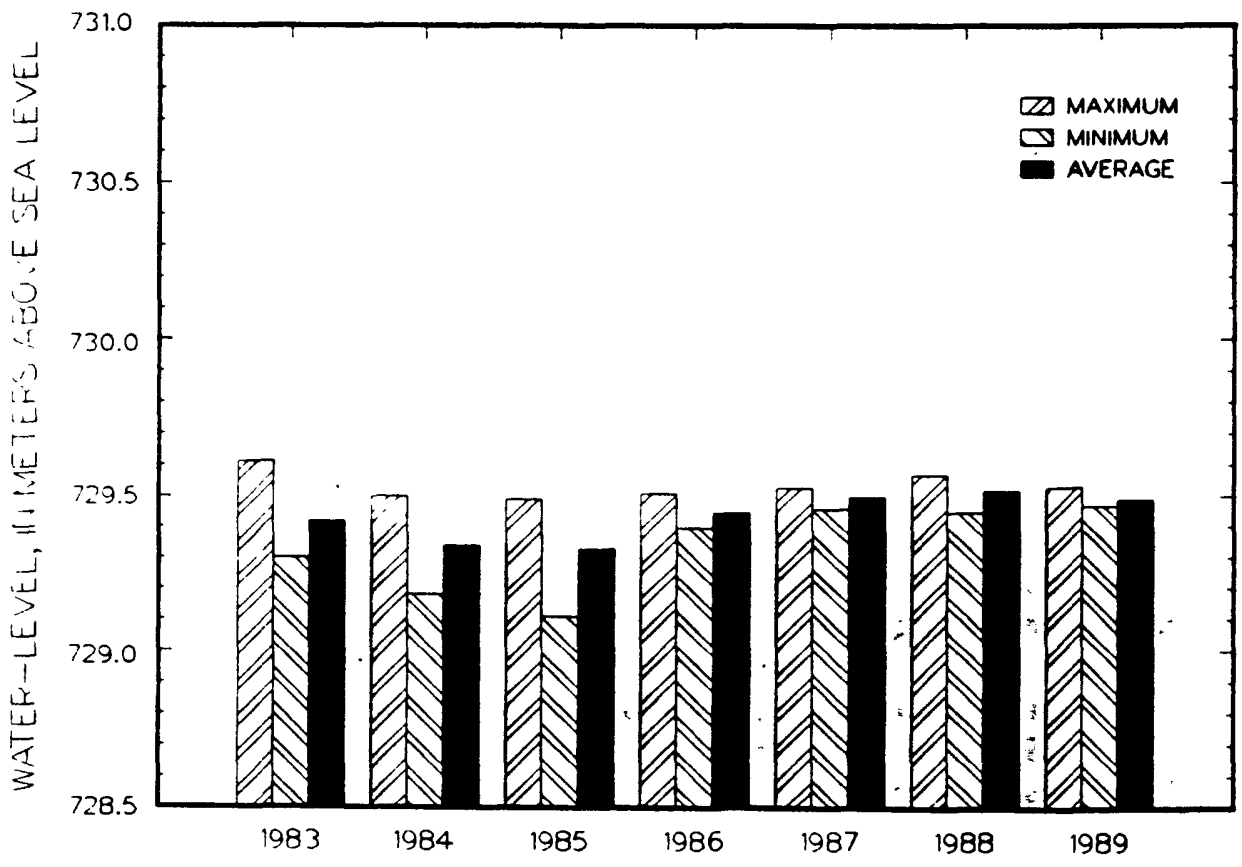


We11 UE-25 WT \#14

1. References or information sources: Robison (1984, 1986); Robison and others (1988); Holmes \& Narver, Inc., (written commun., 1986); Fenix \& Scisson, Inc. (1986a, 1987).

2. Well specifications:

a. Location:

Nevada State Central Zone Coordinates (m): N 232,151; E 175, 324.

Latitude and longitude: $36^{\circ} 50^{\prime} 32^{\prime \prime}$ N.; $116^{\circ} 24^{\prime} 35^{\prime \prime} \mathrm{W}$.

Site ID: 365032116243501 .

b. Land-surface altitude: 1,075.9 m (Robison, 1986; based on survey by U.S. Geological Survey, 1984).

c. Date drilling started: August 17, 1983.

d. Date drilling completed: September 30, 1983.

e. Drilling method: Rotary, using rock bits and air-foam circulating medium; bottom-hole core obtained.

f. Total drilled depth: $399.3 \mathrm{~m}$.

g. Bit diameter below water level: $222.2 \mathrm{~mm}$.

h. Casing extending below water level: None (surface casing only, to a depth of $36.6 \mathrm{~m}$ ).

i. Description of access for measuring water levels, including tubes or piezometers: $61-\mathrm{mm}$ inside-diameter tubing that has a $3.7-\mathrm{m}-$ long well screen on the bottom; tubing and attached screen extend from land surface to a depth of $397.2 \mathrm{~m}$; saturated interval of borehole within Topopah Spring Member of Paintbrush Tuff and tuffaceous beds of Calico Hills.

j. Description and altitude of reference point: Top of metal tag on well casing, 1,076.05 m (surveyed by U.S. Geological Survey, 1984).

k. Description and height of MP above reference point: Top of access tube, $0.311 \mathrm{~m}$.

1. Depth correction for measured water levels because of borehole deviation from vertical (the correction is subtracted from measured depth to obtain true depth): $0.087 \mathrm{~m}$, based on approximate depth to water of $345.9 \mathrm{~m}$.

3. History of instrumentation and water-level measurements, and comments:

The water-level measurements were made using a multiconductor-cable unit (logging van I-127410) from October 21, 1983, through April 29, 1985. Measurements were made using the 2,800-ft reference steel tape from June 11 , 1985, through December 6, 1985, and using the 2,600-ft reeled steel tape from January 28, 1986, through January 9, 1989, except for measurements made March 18 through April 1, 1988, which were made using the 2,800-ft reference steel tape. Chain 非 was used for water-level measurements from February 27, 1989, through December 11, 1989.

From March 22 through 26, 1988, personnel from the Desert Research Institute pumped a total volume of about $9,200 \mathrm{~L}$ of water from the well for the purpose of obtaining water samples. As a result, subsequent water-level measurements might reflect some residual effects from pumping until the saturated interval had sufficient time to recover. 
4. Periodic measurements of water-level altitude in well UE-25 WT \#14:

[Method: S, 2,600-ft Reeled steel tape; R, 2,800-ft Reference steel tape; $C$, Chain 非]

\begin{tabular}{|c|c|c|c|c|c|}
\hline \multirow[b]{2}{*}{ Date } & \multicolumn{2}{|c|}{$\begin{array}{l}\text { Site ID: } \\
\text { Depth interval: }\end{array}$} & \multicolumn{2}{|c|}{$\begin{array}{l}365032116243501 \\
346-399 \mathrm{~m} \text { (composite) }\end{array}$} & \multirow[b]{2}{*}{ Method } \\
\hline & $\begin{array}{l}\text { Water-level } \\
\text { altitude } \\
\text { (meters) }\end{array}$ & Method & Date & $\begin{array}{l}\text { Water-level } \\
\text { altitude } \\
\text { (meters) }\end{array}$ & \\
\hline $\begin{array}{l}01 / 26 / 88 \\
02 / 16 / 88 \\
03 / 18 / 88 \\
03 / 21 / 88\end{array}$ & $\begin{array}{l}729.69 \\
729.73 \\
729.67 \\
729.72\end{array}$ & $\begin{array}{l}S \\
S \\
R \\
R\end{array}$ & $\begin{array}{l}12 / 20 / 88 \\
01 / 09 / 89 \\
02 / 27 / 89 \\
03 / 14 / 89\end{array}$ & $\begin{array}{l}729.70 \\
729.68 \\
729.75 \\
729.73\end{array}$ & $\begin{array}{l}S \\
S \\
C \\
C\end{array}$ \\
\hline $\begin{array}{l}03 / 31 / 88 \\
04 / 01 / 88 \\
04 / 19 / 88 \\
05 / 26 / 88\end{array}$ & $\begin{array}{l}729.69 \\
729.69 \\
729.73 \\
729.70\end{array}$ & $\begin{array}{l}R \\
R \\
S \\
S\end{array}$ & $\begin{array}{l}04 / 25 / 89 \\
05 / 24 / 89 \\
06 / 30 / 89 \\
07 / 19 / 89\end{array}$ & $\begin{array}{l}729.71 \\
729.72 \\
729.72 \\
729.72\end{array}$ & $\begin{array}{l}C \\
C \\
C \\
C\end{array}$ \\
\hline $\begin{array}{l}06 / 28 / 88 \\
07 / 11 / 88 \\
08 / 10 / 88 \\
09 / 14 / 88 \\
10 / 28 / 88\end{array}$ & $\begin{array}{l}729.72 \\
729.72 \\
729.74 \\
729.71 \\
729.70\end{array}$ & $\begin{array}{l}S \\
S \\
S \\
S \\
S\end{array}$ & $\begin{array}{l}08 / 14 / 89 \\
10 / 03 / 89 \\
11 / 16 / 89 \\
12 / 11 / 89\end{array}$ & $\begin{array}{l}729.72 \\
729.73 \\
729.75 \\
729.67\end{array}$ & $\begin{array}{l}c \\
C \\
C \\
C\end{array}$ \\
\hline
\end{tabular}

5. Hydrograph of water-level altitude (plotted from data in section 4):

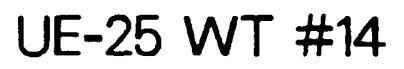

Site 1D: 365032116243501

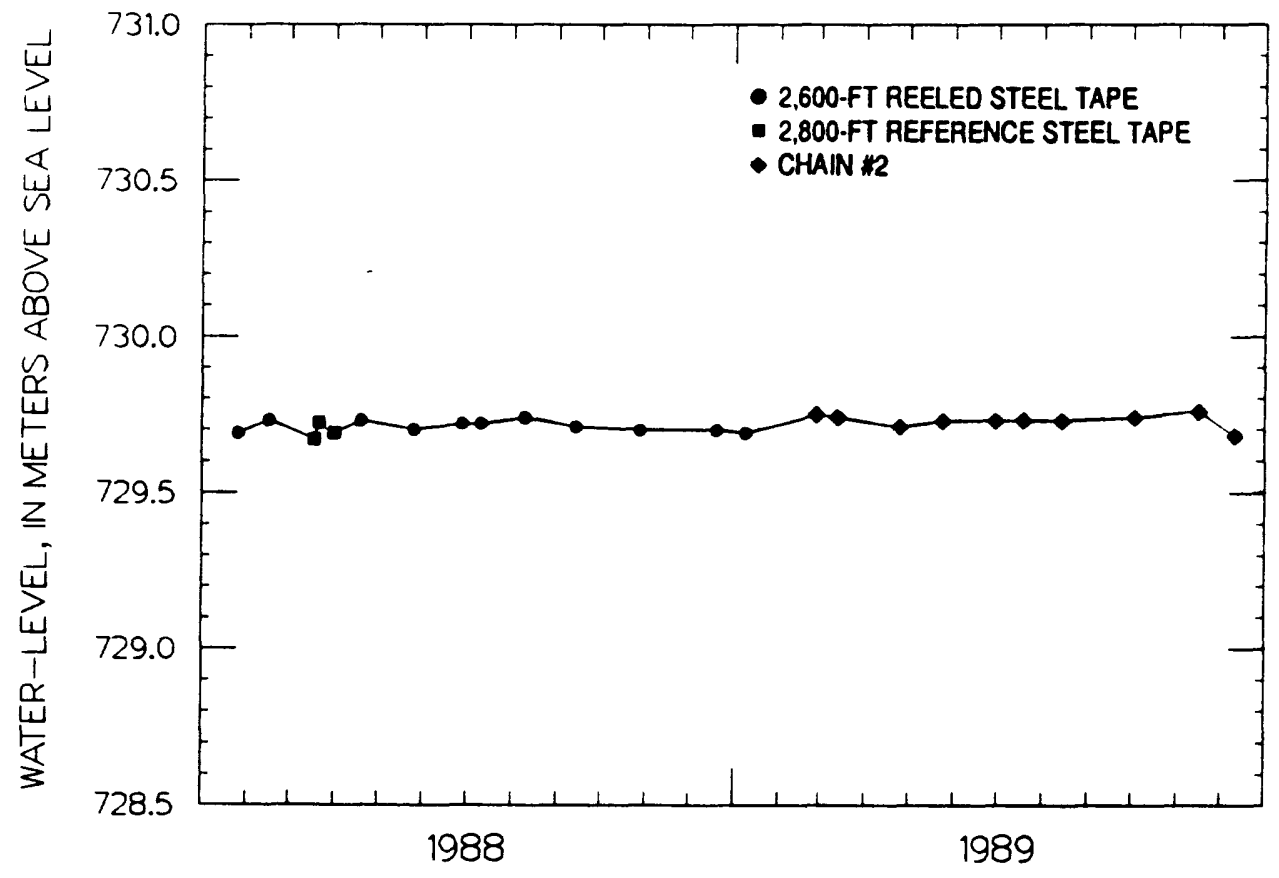


6. Maximum, minimum, and average water-level altitudes for we11 UE-25 WT 非14:

\begin{tabular}{cccccc}
\hline \multirow{2}{*}{$\begin{array}{c}\text { Calendar } \\
\text { year }\end{array}$} & \multicolumn{2}{c}{ Water-level } & altitude (meters) & $\begin{array}{c}\text { Range } \\
\text { (meters) }\end{array}$ & $\begin{array}{c}\text { Number of } \\
\text { measure- } \\
\text { ments }\end{array}$ \\
\cline { 2 - 4 } 11983 & 729.75 & 729.47 & 729.61 & 0.28 & 8 \\
1984 & 729.64 & 729.45 & 729.55 & 0.19 & 23 \\
1985 & 729.63 & 729.29 & 729.54 & 0.34 & 14 \\
1986 & 729.71 & 729.63 & 729.68 & 0.08 & 16 \\
1987 & 729.98 & 729.64 & 729.71 & 0.34 & 13 \\
1988 & 729.74 & 729.67 & 729.71 & 0.07 & 14 \\
1989 & 729.75 & 729.67 & 729.72 & 0.08 & 11 \\
\hline
\end{tabular}

1 October-December.

7. Bar graph of annual maximum, minimum, and average water-level altitudes (plotted from data in section 6):

UE-25 WT \#14

Site ID: 365032116243501

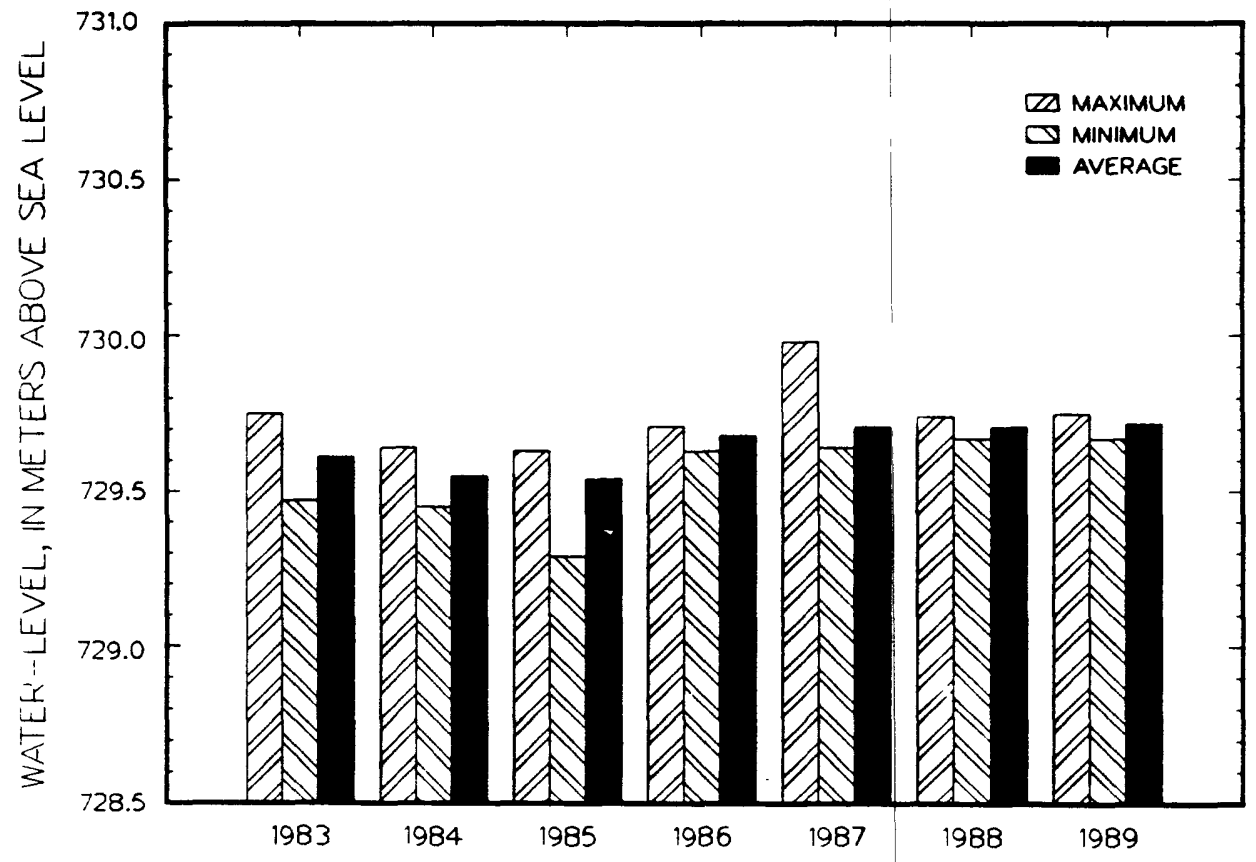


1. References or information sources: Robison (1984, 1986); Robison and others (1988); Holmes \& Narver, Inc. (written commun., 1986); Fenix \& Scisson, Inc. (1986a, 1987).

2. Well specifications:

a. Location:

Nevada State Central Zone Coordinates (m): N 233,512; E 176,725. Latitude and longitude: $36^{\circ} 51^{\prime} 16^{\prime \prime} \mathrm{N}$.; $116^{\circ} 23^{\prime} 38^{\prime \prime} \mathrm{W}$.

Site ID: 365116116233801.

b. Land-surface altitude: 1,083.2 m (Robison, 1986; based on survey by U.S. Geological Survey, 1984).

c. Date drilling started: November 12, 1983.

d. Date drilling completed: November 22, 1983.

e. Drilling method: Rotary, using rock bits and air-foam circulating medium; bottom-hole core obtained.

f. Total drilled depth: $414.6 \mathrm{~m}$.

g. Bit diameter below water level: $222.2 \mathrm{~mm}$.

h. Casing extending below water level: None (surface casing only, to a depth of $38.7 \mathrm{~m}$ ).

i. Description of access for measuring water levels, including tubes or piezometers: $61-\mathrm{mm}$ inside-diameter tubing that has a $3.7-\mathrm{m}-$ long well screen on the bottom; tubing and attached screen extend from land surface to a depth of $406.9 \mathrm{~m}$; saturated interval of borehole within Topopah Spring Member of Paintbrush Tuff.

j. Description and altitude of reference point: Top of metal tag on well casing, 1,082.94 m (surveyed by U.S. Geological Survey, 1984).

k. Description and height of MP above reference point: Top of access tube, $0.314 \mathrm{~m}$.

1. Depth correction for measured water levels because of borehole deviation from vertical (the correction is subtracted from measured depth to obtain true depth): $0.188 \mathrm{~m}$, based on approximate depth to water of $353.6 \mathrm{~m}$.

3. History of instrumentation and water-level measurements, and comments:

The water-level measurements were made using a multiconductor-cable unit (logging van I-127410) from November 29, 1983, through April 29, 1985.

Measurements were made using the 2,800-ft reference steel tape from June 11 , 1985, through December 30, 1985, and using the 2,600-ft reeled steel tape from January 28, 1986, through January 9, 1989. Chain 非 was used to measure water levels from February 23, 1989, through December 11, 1989.

From April 18 through 25, 1988, personnel from the Desert Research Institute pumped a total volume of about $11,000 \mathrm{~L}$ of water from the well for the purpose of obtaining water samples. As a result, subsequent water-level measurements might reflect some residual effects from pumping until the saturated interval had sufficient time to recover. 
4. Periodic measurements of water-level altitude in well UE-25 WT 非15:

[Method: S, 2,600-ft Reeled steel tape; C, Chain 非]

\begin{tabular}{|c|c|c|c|c|c|}
\hline \multirow[b]{2}{*}{ Date } & \multicolumn{2}{|c|}{ Depth interval: } & \multicolumn{2}{|c|}{$\begin{array}{l}365116116233801 \\
354-415 \mathrm{~m} \text { (composite) }\end{array}$} & \multirow[b]{2}{*}{ Method } \\
\hline & $\begin{array}{l}\text { Water-level } \\
\text { altitude } \\
\text { (meters) }\end{array}$ & Method & Date & $\begin{array}{l}\text { Water-level } \\
\text { altitude } \\
\text { (meters) }\end{array}$ & \\
\hline $\begin{array}{l}01 / 27 / 88 \\
02 / 16 / 88 \\
04 / 18 / 88 \\
04 / 25 / 88\end{array}$ & $\begin{array}{l}729.23 \\
729.24 \\
729.24 \\
729.18\end{array}$ & $\begin{array}{l}S \\
S \\
S \\
S\end{array}$ & $\begin{array}{l}01 / 09 / 89 \\
02 / 23 / 89 \\
03 / 13 / 89 \\
04 / 26 / 89\end{array}$ & $\begin{array}{l}729.17 \\
729.26 \\
729.29 \\
729.28\end{array}$ & $\begin{array}{l}S \\
C \\
C \\
C\end{array}$ \\
\hline $\begin{array}{l}04 / 26 / 88 \\
05 / 26 / 88 \\
06 / 30 / 88 \\
07 / 14 / 88\end{array}$ & $\begin{array}{l}729.21 \\
729.24 \\
729.24 \\
729.24\end{array}$ & $\begin{array}{l}\mathrm{S} \\
\mathrm{S} \\
\mathrm{S} \\
\mathrm{S}\end{array}$ & $\begin{array}{r}05 / 30 / 89 \\
-06 / 30 / 89 \\
07 / 24 / 89 \\
08 / 14 / 89\end{array}$ & $\begin{array}{l}729.22 \\
729.23 \\
729.23 \\
729.27\end{array}$ & $\begin{array}{l}c \\
C \\
C \\
C\end{array}$ \\
\hline $\begin{array}{l}08 / 19 / 88 \\
09 / 14 / 88 \\
10 / 28 / 88 \\
12 / 20 / 88\end{array}$ & $\begin{array}{l}729.28 \\
729.21 \\
729.25 \\
729.26\end{array}$ & $\begin{array}{l}S \\
S \\
S \\
S\end{array}$ & $\begin{array}{l}10 / 03 / 89 \\
11 / 16 / 89 \\
12 / 11 / 89\end{array}$ & $\begin{array}{l}729.28 \\
729.27 \\
729.19\end{array}$ & $\begin{array}{l}C \\
C \\
C\end{array}$ \\
\hline
\end{tabular}

5. Hydrograph of water-level altitude (plotted from data in section 4):

\section{UE-25 WT \#15}

Site ID: 365116116233801

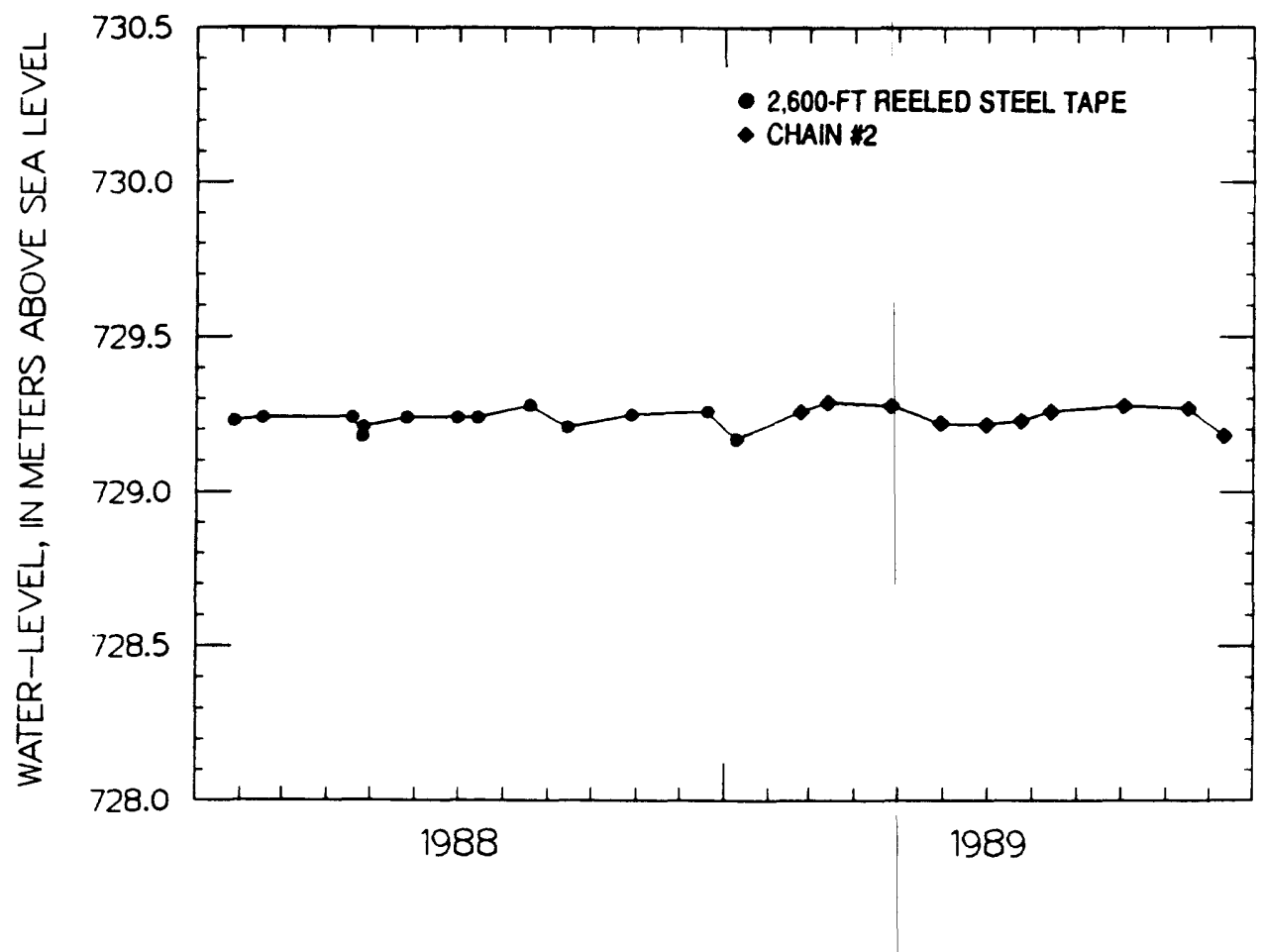


6. Maximum, minimum, and average water-level altitudes for wel1 UE-25 WT 非15:

\begin{tabular}{|c|c|c|c|c|c|}
\hline \multirow{2}{*}{$\begin{array}{c}\text { Calendar } \\
\text { year }\end{array}$} & \multicolumn{3}{|c|}{ Water-level altitude (meters) } & \multirow{2}{*}{$\begin{array}{l}\text { Range } \\
\text { (meters) }\end{array}$} & \multirow{2}{*}{$\begin{array}{c}\text { Number of } \\
\text { measure- } \\
\text { ments }\end{array}$} \\
\hline & Maximum & Minimum & Average & & \\
\hline${ }^{1} 1983$ & 729.15 & 728.98 & 729.07 & 0.17 & 7 \\
\hline 1984 & 729.21 & 728.96 & 729.07 & 0.25 & 24 \\
\hline 1985 & 729.23 & 728.98 & 729.08 & 0.25 & 12 \\
\hline 1986 & 729.27 & 729.19 & 729.23 & 0.08 & 15 \\
\hline 1987 & 729.25 & 729.16 & 729.22 & 0.09 & 12 \\
\hline 1988 & 729.28 & 729.18 & 729.24 & 0.10 & 12 \\
\hline 1989 & 729.29 & 729.17 & 729.24 & 0.12 & 11 \\
\hline
\end{tabular}

${ }^{1}$ November-December.

7. Bar graph of annual maximum, minimum, and average water-level altitudes (plotted from data in section 6):

\section{UE-25 WT \#15}

Site 1D: 365116116233801

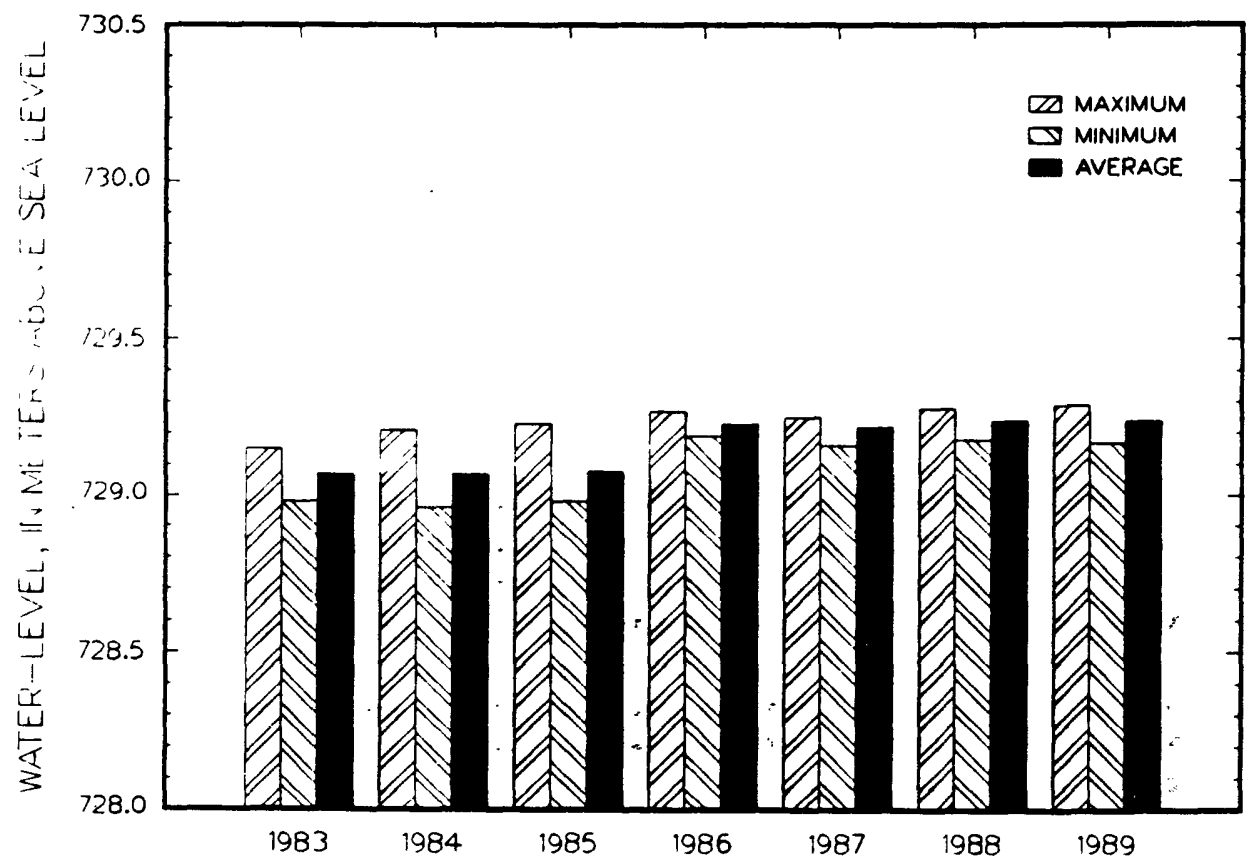




\section{We11 UE-25 WT 非17}

1. References or information sources: Robison (1984, 1986); Robison and others (1988); Holmes \& Narver, Inc. (written commun., 1986); Fenix \& Scisson, Inc. (1986a, 1987).

2. Well specifications:

a. Location:

Nevada State Central Zone Coordinates (m): N 228,118; E 172,581.

Latitude and longitude: $36^{\circ} 48^{\prime} 22^{\prime \prime} \mathrm{N}$.; $116^{\circ} 26^{\prime} 26^{\prime \prime} \mathrm{W}$.

Site ID: 364822116262601.

b. Land-surface altitude: 1,124.0 m (Robison, 1986; based on survey by U.S. Geological Survey, 1984).

c. Date drilling started: October 20, 1983.

d. Date drilling completed: October 30, 1983.

e. Drilling method: Rotary, using rock bits and air-foam circulating medium; attempt to obtain bottom-hole core unsuccessful.

f. Total drilled depth: $442.9 \mathrm{~m}$.

g. Bit diameter below water level: $222.2 \mathrm{~mm}$.

h. Casing extending below water level: None (surface casing only, to a depth of $16.8 \mathrm{~m}$ ).

i. Description of access for measuring water levels, including tubes or piezometers: $61-\mathrm{mm}$ inside-diameter tubing that has a $3.7-\mathrm{m}-$ long well screen on the bottom; tubing and attached screen extend from land surface to a depth of $419.4 \mathrm{~m}$; saturated interval of borehole within Prow Pass Member of Crater Flat Tuff.

j. Description and altitude of reference point: Top of metal tag on well casing, 1,124.06 m (surveyed by U.S. Geological Survey, 1984).

k. Description and height of MP above reference point: Top of access tube, $0.158 \mathrm{~m}$.

1. Depth correction for measured water levels because of borehole deviation from vertical (the correction is subtracted from measured depth to obtain true depth): $0.481 \mathrm{~m}$, based on approximate depth to water of $395.0 \mathrm{~m}$.

3. History of instrumentation and water-level measurements, and comments:

The water-level measurements were made using a multiconductor-cable unit (logging van I-127410) from October 31, 1983, through April 11, 1985.

Measurements were made using the 2,800-ft reference steel tape from June 12 , 1985, through November 20, 1985, and using the 2,600-ft reeled steel tape from January 27, 1986, through April 25, 1988. The multiconductor cable unit housed in van I-133970 was used to make water-level measurements from May 24, 1988, through February 21, 1989. Chain 非 was used to measure water-levels from March 14, 1989, through December 27, 1989. 
4. Periodic measurements of water-level altitude in well UE-25 WT 非17:

[Method: S, 2,600-ft Reeled steel tape; V, Multiconductor cable; C, Chain 非]

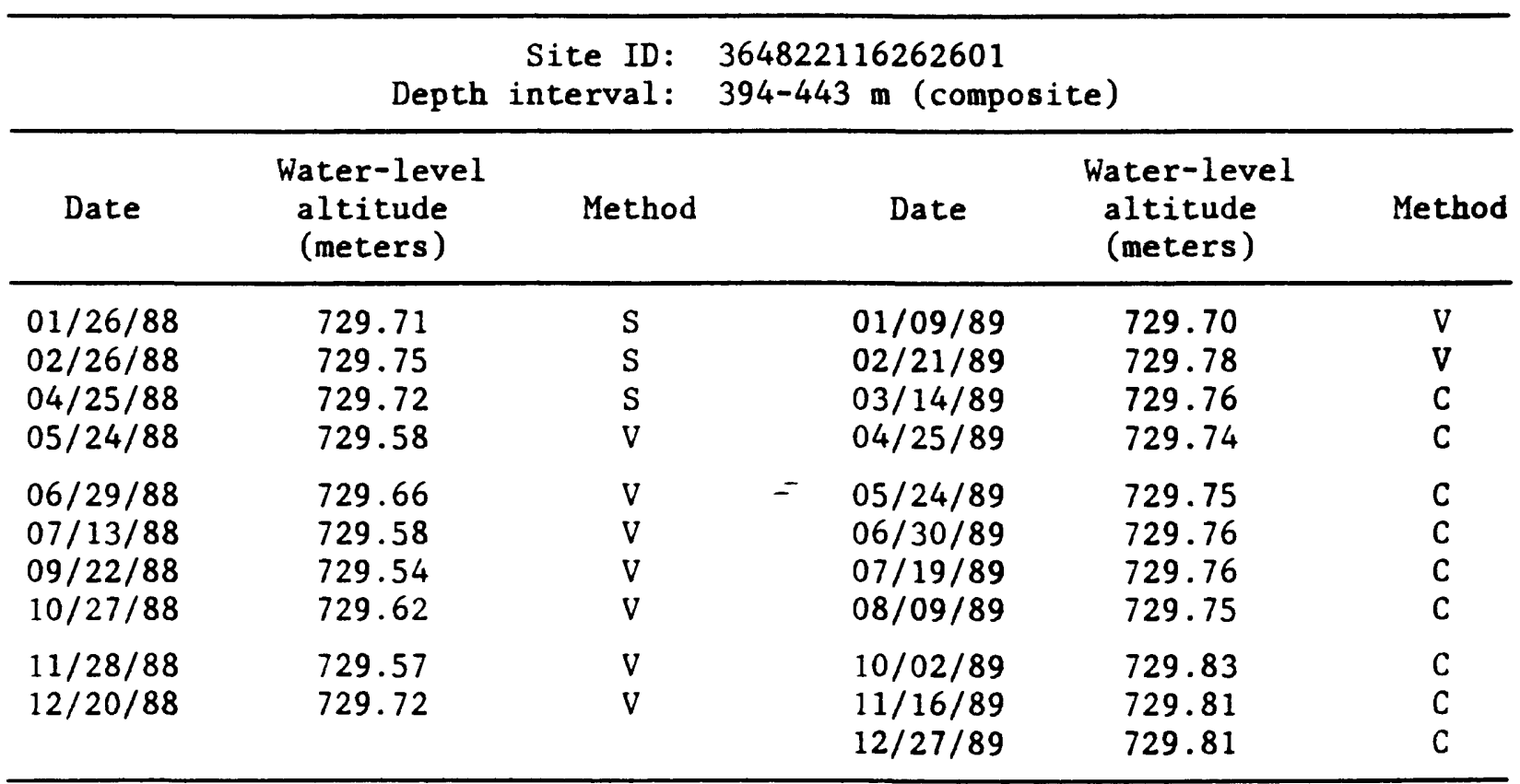

5. Hydrograph of water-level altitude (plotted from data in section 4):

UE-25 WT \#17

Site ID: 364822116262601

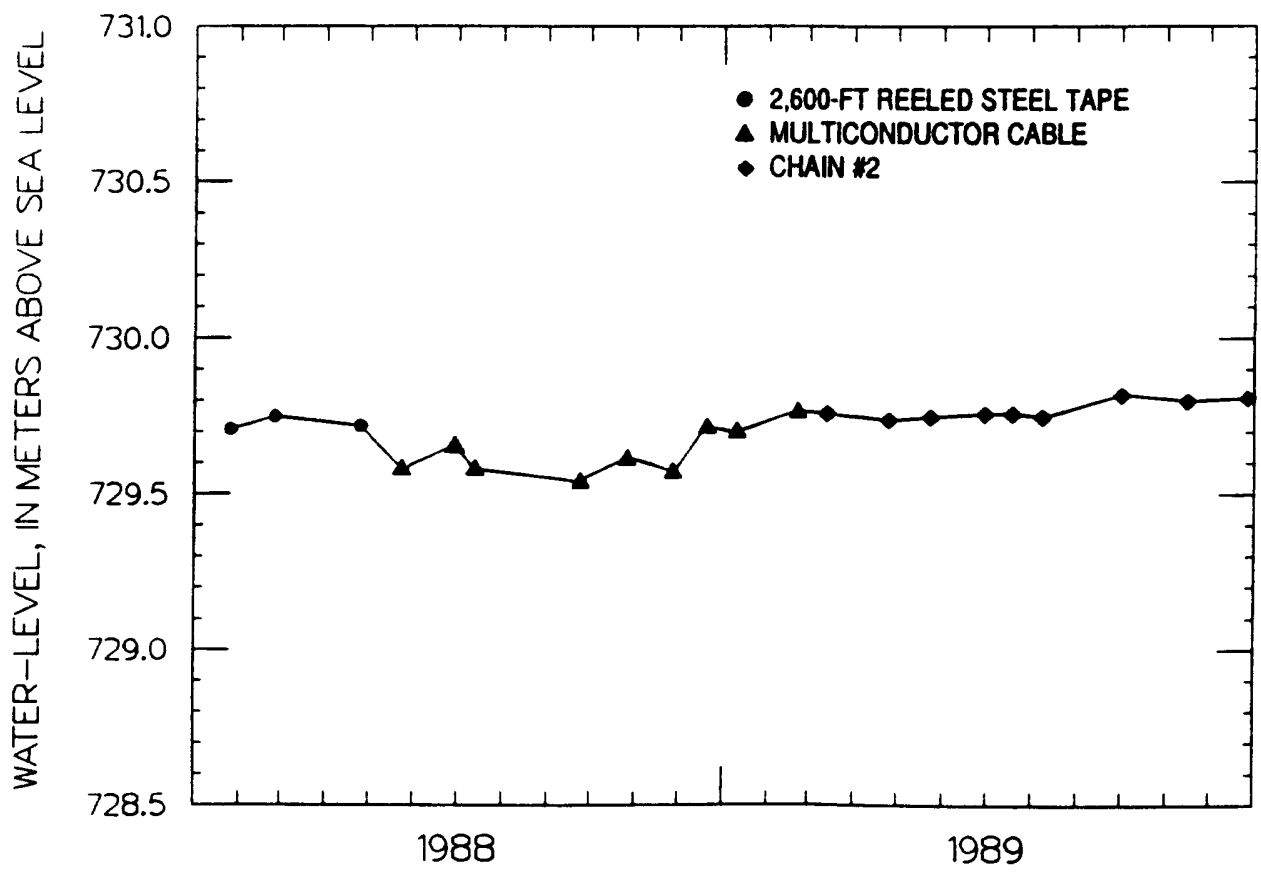


6. Maximum, minimum, and average water-level altitudes for well UE-25 WT 非17:

\begin{tabular}{|c|c|c|c|c|c|}
\hline \multirow{2}{*}{$\begin{array}{c}\text { Calendar } \\
\text { year }\end{array}$} & \multicolumn{3}{|c|}{ Water-level altitude (meters) } & \multirow{2}{*}{$\begin{array}{l}\text { Range } \\
\text { (meters) }\end{array}$} & \multirow{2}{*}{$\begin{array}{c}\text { Number of } \\
\text { measure- } \\
\text { ments }\end{array}$} \\
\hline & Maximum & Minimum & Average & & \\
\hline${ }_{1}^{1983}$ & 729.72 & 729.50 & 729.58 & 0.22 & 7 \\
\hline 1984 & 729.66 & 729.35 & 729.54 & 0.31 & 21 \\
\hline 1985 & 729.68 & 729.45 & 729.55 & 0.23 & 9 \\
\hline 1986 & 729.77 & 729.60 & 729.71 & 0.17 & 16 \\
\hline 1987 & 729.75 & 729.68 & 729.71 & 0.07 & 14 \\
\hline 1988 & 729.75 & 729.54 & 729.64 & 0.21 & 10 \\
\hline 1989 & 729.83 & 729.70 & 729.77 & 0.13 & 11 \\
\hline
\end{tabular}

${ }^{1}$ October-December.

7. Bar graph of annual maximum, minimum, and average water-level altitudes (plotted from data in section 6):

UE-25 WT \#17

Site ID: 364822116262601

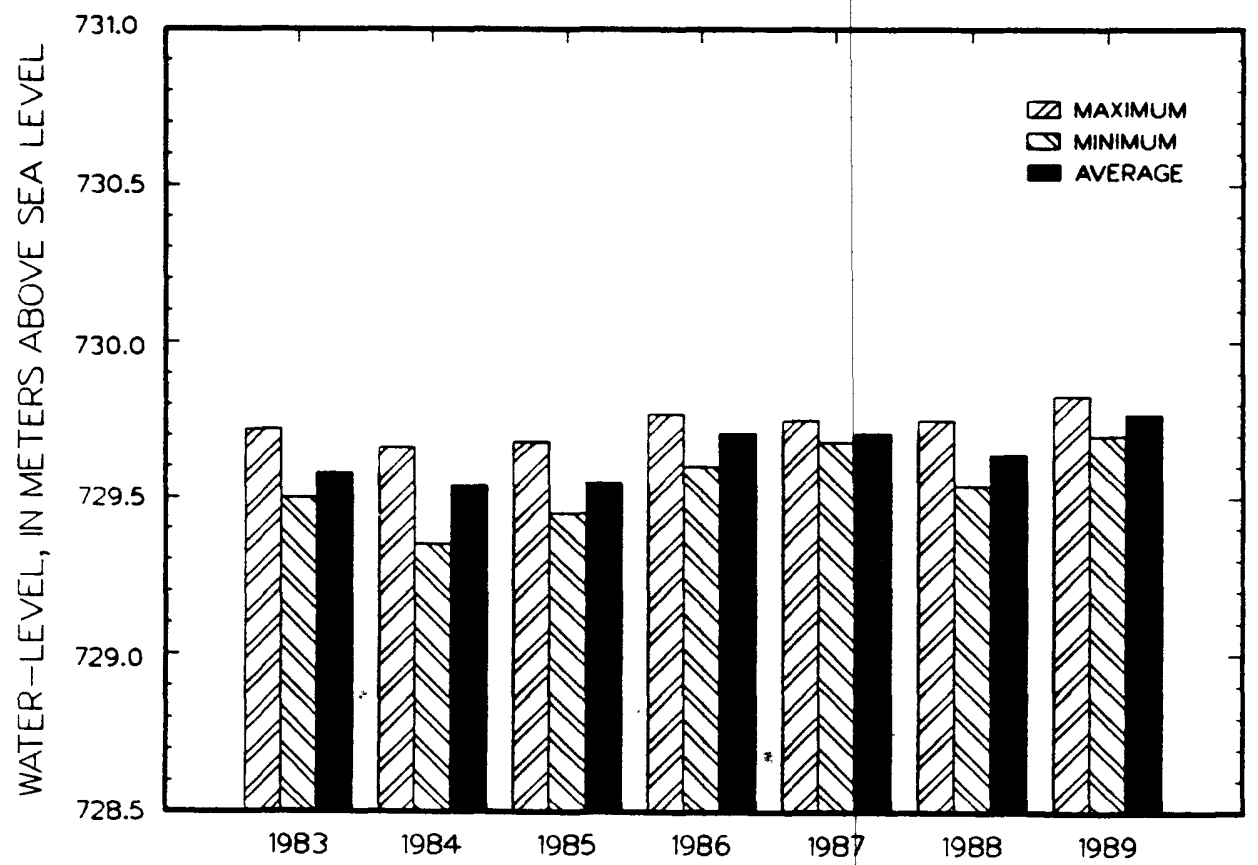




\section{Well USW VH-1}

1. References or information sources: Robison (1984, 1986); Robison and others (1988); Holmes \& Narver, Inc. (written commun., 1986); Fenix \& Scisson, Inc. (1986b, 1987); Thordarson and Howells (1987).

2. Well specifications:

a. Location:

Nevada State Central Zone Coordinates (m): N 226,575; E 162,649. Latitude and longitude: $36^{\circ} 47^{\prime} 32^{\prime \prime} \mathrm{N} . ; 116^{\circ} 33^{\prime} 07^{\prime \prime} \mathrm{W}$.

Site ID: 364732116330701.

b. Land-surface altitude: $963.5 \mathrm{~m}$ (Robison, 1986).

c. Date drilling started: October 28, 1980.

d. Date drilling completed: February 18, 1981.

e. Drilling method: Rotary, using rock bits, and air-foam and polymer circulating medium.

f. Total drilled depth: $762.3 \mathrm{~m}$ :

g. Bit diameter below water level: $222.2 \mathrm{~mm}$ to $278.0 \mathrm{~m} ; 158.8 \mathrm{~mm}$ from $278.0 \mathrm{~m}$ to total depth.

h. Casing extending below water level: $177.0-\mathrm{mm}$ inside diameter to $277.7 \mathrm{~m}$.

i. Description of access for measuring water levels, including tubes or piezometers: $48-\mathrm{mm}$ inside-diameter tubing, open ended from land surface to $205.4 \mathrm{~m}$; saturated interval of well within Tiva Canyon, Topopah Spring, Prow Pass, and Bullfrog Members of Paintbrush Tuff. A pump was installed in the well on July 8, 1982, at a depth of $212.8 \mathrm{~m}$.

j. Description and altitude of reference point: Top of casing, $963.23 \mathrm{~m}$ (Holmes \& Narver, Inc., March 3, 1986).

$k$. Description and height of MP above land surface: Top of casing, $0.314 \mathrm{~m}$.

1. Depth correction for measured water levels because of borehole deviation from vertical (the correction is subtracted from measured depth to obtain true depth): $0.050 \mathrm{~m}$, based on approximate depth to water of $184.1 \mathrm{~m}$.

3. History of instrumentation and water-level measurements, and comments:

The water-level measurements were made using a multiconductor-cable unit (logging van I-127410) from April 12, 1984, through April 16, 1985; measurements were made using a 2,800-ft reference steel tape during the remainder of 1985. Measurements were made using a 2,600-ft reeled steel tape from January 22, 1986, through April 5, 1988. Measurements were made using a multiconductor-cable unit housed in van I-133970 from May 17, 1988, through February 16, 1989. Chain 非 was used to measure water levels from March 23, 1989, through December 21, 1989. 
4. Periodic measurements of water-level altitude in well USW VH-1:

[Method: S, 2,600-ft Reeled steel tape; V, Multiconductor cable; C, Chain 非]

Site ID: 364732116330701

Depth interval: $185-762 \mathrm{~m}$ (composite)

\begin{tabular}{cccccc}
\hline Date & $\begin{array}{c}\text { Water-level } \\
\text { altitude } \\
\text { (meters) }\end{array}$ & Method & Date & $\begin{array}{c}\text { Water-level } \\
\text { altitude } \\
\text { (meters) }\end{array}$ & Method \\
\hline $01 / 22 / 88$ & 779.37 & $\mathrm{~S}$ & $12 / 21 / 88$ & 779.51 & $\mathrm{~V}$ \\
$02 / 24 / 88$ & 779.44 & $\mathrm{~S}$ & $01 / 19 / 89$ & 779.53 & $\mathrm{~V}$ \\
$03 / 07 / 88$ & 779.39 & $\mathrm{~S}$ & $02 / 16 / 89$ & 779.54 & $\mathrm{~V}$ \\
$04 / 05 / 88$ & 779.41 & $\mathrm{~S}$ & $03 / 23 / 89$ & 779.49 & $\mathrm{C}$ \\
$05 / 17 / 88$ & 779.51 & $\mathrm{~V}$ & $-04 / 21 / 89$ & 779.49 & $\mathrm{C}$ \\
$06 / 23 / 88$ & 779.47 & $\mathrm{~V}$ & $05 / 18 / 89$ & 779.47 & $\mathrm{C}$ \\
$07 / 08 / 88$ & 779.48 & $\mathrm{~V}$ & $07 / 18 / 89$ & 779.47 & $\mathrm{C}$ \\
$08 / 17 / 88$ & 779.47 & $\mathrm{~V}$ & $10 / 04 / 89$ & 779.47 & $\mathrm{C}$ \\
$09 / 15 / 88$ & 779.50 & $\mathrm{~V}$ & $11 / 28 / 89$ & 779.37 & $\mathrm{C}$ \\
$10 / 06 / 88$ & 779.51 & $\mathrm{~V}$ & $12 / 21 / 89$ & 779.45 & \\
$11 / 17 / 88$ & 779.49 & $\mathrm{~V}$ & & & \\
\hline
\end{tabular}

5. Hydrograph of water-level altitude (plotted from data in section 4):

\section{USW VH-1}

Site ID: 364732116330701

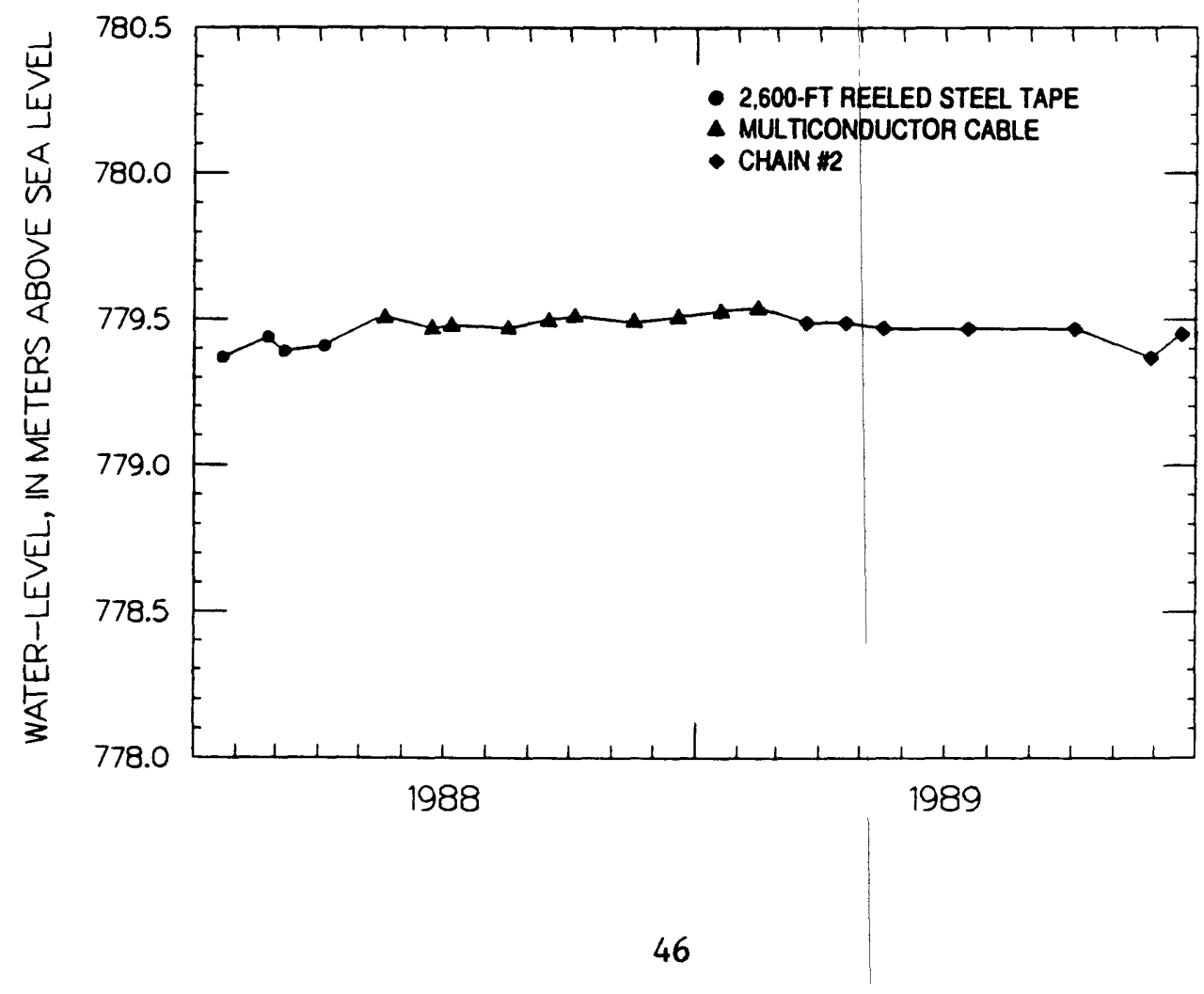


6. Maximum, minimum, and average water-level altitudes for well USW VH-1:

\begin{tabular}{cccccc}
\hline $\begin{array}{c}\text { Calendar } \\
\text { year }\end{array}$ & \multicolumn{2}{c}{ Water-level altitude (meters) } & $\begin{array}{c}\text { Range } \\
\text { (meters) }\end{array}$ & $\begin{array}{c}\text { Number of } \\
\text { measure- } \\
\text { ments }\end{array}$ \\
\cline { 2 - 4 }${ }^{1} 1984$ & 779.44 & 779.23 & 779.36 & 0.21 & 11 \\
1985 & 779.45 & 779.32 & 779.40 & 0.13 & 17 \\
1986 & 779.48 & 779.41 & 779.43 & 0.07 & 13 \\
1987 & 779.50 & 779.33 & 779.42 & 0.17 & 14 \\
1988 & 779.51 & 779.37 & 779.46 & 0.14 & 12 \\
1989 & 779.54 & 779.37 & 779.48 & 0.17 & 9 \\
\hline
\end{tabular}

${ }^{1}$ April-December.

7. Bar graph of annual maximum, minimum, and average water-level altitudes (plotted from data in section 6):

\section{USW VH-1}

Site ID: 364732116330701

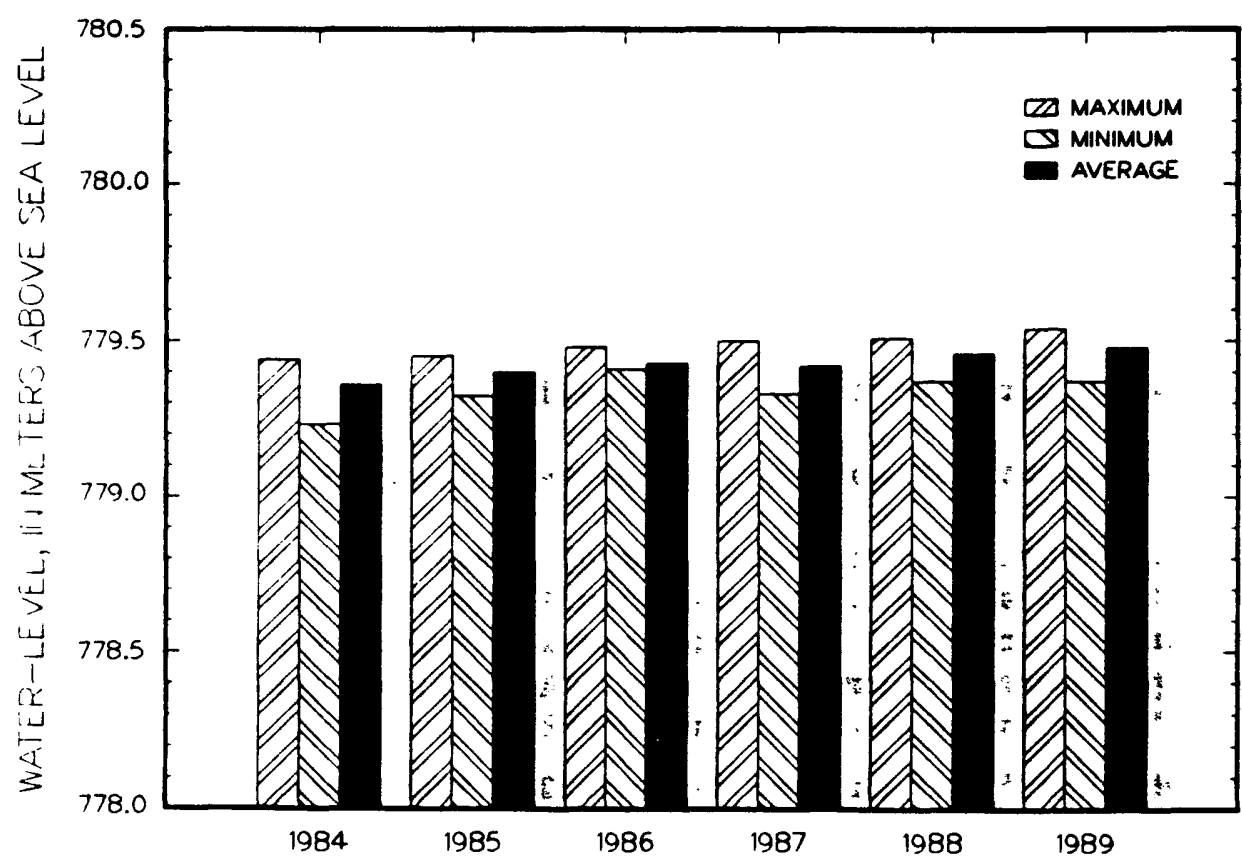


Wel1 J-13

1. References or information sources: Robison (1984, 1986); Robison and others (1988); Holmes \& Narver, Inc. (written commun., 1986); Thordarson (1983); Young (1972); Fenix \& Scisson (1987).

2. Well specifications:

a. Location:

Nevada State Central Zone Coordinates (m): N 228,359; E 176,678. Latitude and longitude: $36^{\circ} 48^{\prime} 29^{\prime \prime} \mathrm{N} . ; 116^{\circ} 23^{\prime} 40^{\prime \prime} \mathrm{W}$.

Site ID: 364828116234001.

b. Land-surface altitude: 1,011.3 m (Robison, 1986).

c. Date drilling started: September 12, 1962.

d. Date drilling completed: January 8, 1963.

e. Drilling method: Rotary, using air and aerated mud as circulating medium.

f. Total drilled depth: 1,063.1 m:

8. Bit diameter below water level: $438.2 \mathrm{~mm}$ to $402.0 \mathrm{~m} ; 380 \mathrm{~mm}$ from $402.0 \mathrm{~m}$ to $471.2 \mathrm{~m} ; 193.5 \mathrm{~mm}$ from $471.2 \mathrm{~m}$ to total depth.

h. Casing extending below water level: 323- $\mathrm{mm}$ inside diameter, from land surface to $396.5 \mathrm{~m} ; 282-\mathrm{mm}$ inside diameter from 396.5 to $471.2 \mathrm{~m} ; 125.7-\mathrm{mm}$ inside diameter from 452.3 to $1,031.7 \mathrm{~m}$; casing perforated from 303.6 to $423.7 \mathrm{~m}$ within Topopah Spring Member of Paintbrush Tuff, and from 819.9 to $1,009.5 \mathrm{~m}$ within Tram Member of Crater Flat Tuff and upper part of Lithic Ridge Tuff.

i. Description of access for measuring water levels, including tubes or piezometers: Access tube installed in 1986, in order for measuring equipment to safely bypass pump assembly.

j. Description and altitude of reference point: Chiseled square on concrete well collar, 1,011.47 m (surveyed by U.S. Geological Survey, 1984).

k. Description and height of MP above reference point: Top of access tube, $0.165 \mathrm{~m}$.

1. Depth correction for measured water levels because of well deviation from vertical: Not available.

3. History of instrumentation and water-level measurements, and comments:

Well J-13 was completed in 1963 to supply water for activities in the western part of the Nevada Test Site and continues to serve that purpose. In automatic response to needs of the connected water-supply system, well J-13 typically is pumped several times per day. The well has been reported to yield about $50.5 \mathrm{~L} / \mathrm{s}$ (Robison and others, 1988).

From December 30,1962, through August 20,1980, occasional measurements of the static water level were made at well $\mathrm{J}-13$ and were reported by Thordarson (1983). Only one water-level measurement was made in 1962, 1967, 1969, and 1980, so the data are not included in section 6, "Maximum, minimum, and average water-level altitudes for well $\mathrm{J}-13^{\prime \prime}$.

An attempt to continuously monitor the water level in this well was begun in September 1986. Two water-level measurements were made in September 1386 during the process of installing and calibrating the continuous monitoring equipment. The results are published in Robison and others (1988). By the end of 1988 it was apparent that the quantity of usable, continuous waterlevel data that had been collected was insufficient to support any type of 
meaningful analysis. In $1989, \mathrm{~J}-13$ was considered part of the periodic network and water-level measurements were made with chain 非. During 1989, J-13 was still being used as a water-supply well and was subject to pumping that may affect the water-level altitude.

4. Periodic measurements of water-level altitude in well $\mathrm{J}-13$ :

[Method: S, 2,600-ft Reeled steel tape; C, Chain 非]

Site ID: 364828116234001

Depth interval: 283-1,063 m (composite)

\begin{tabular}{|c|c|c|c|c|c|c|}
\hline Date & $\begin{array}{l}\text { Water-level } \\
\text { altitude } \\
\text { (meters) }\end{array}$ & Method & & Date & $\begin{array}{l}\text { Water-level } \\
\text { altitude } \\
\text { (meters) }\end{array}$ & Method \\
\hline $01 / 26 / 88$ & 730.38 & S & $=$ & $01 / 09 / 89$ & 730.37 & $\mathbf{S}$ \\
\hline $03 / 04 / 88$ & 728.42 & $\mathrm{~S}$ & & $05 / 30 / 89$ & 728.41 & $\mathrm{C}$ \\
\hline $07 / 07 / 88$ & 728.41 & $\mathrm{~S}$ & & $07 / 21 / 89$ & 728.48 & C \\
\hline $10 / 26 / 88$ & 728.53 & $\mathrm{~S}$ & & $08 / 14 / 89$ & 728.48 & C \\
\hline $01 / 18 / 89$ & 728.45 & $C$ & & $11 / 21 / 89$ & 728.48 & C \\
\hline $02 / 22 / 89$ & 728.40 & C & & $12 / 20 / 89$ & 728.44 & C \\
\hline $03 / 22 / 89$ & 728.49 & C & & & & \\
\hline
\end{tabular}

5. Hydrograph of water-level altitude (plotted from data in section 4):

$J-13$

Site ID: 364828116234001

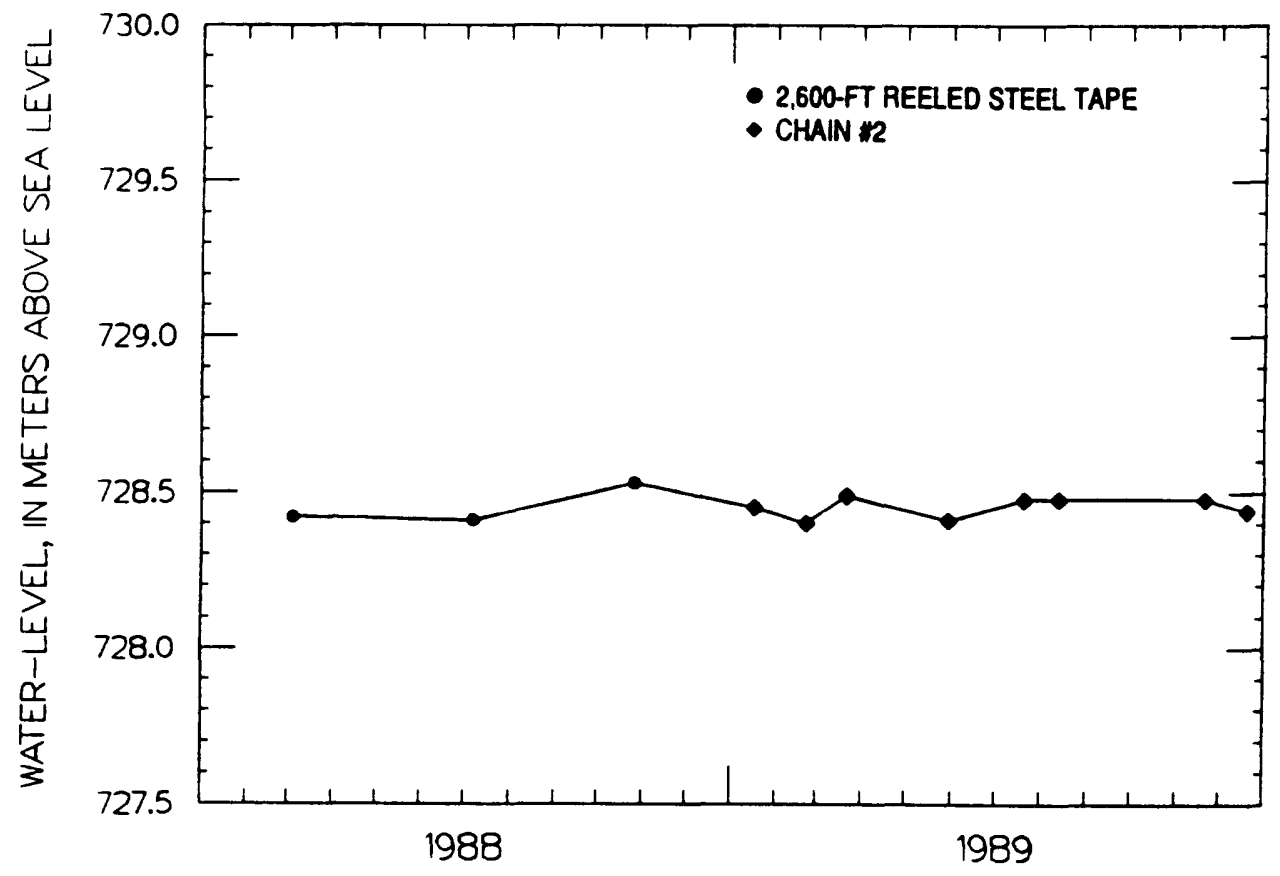


6. Maximum, minimum, and average water-level altitudes for well $\mathrm{J}-13$ :

\begin{tabular}{|c|c|c|c|c|c|}
\hline \multirow{2}{*}{$\begin{array}{c}\text { Calendar } \\
\text { year }\end{array}$} & \multicolumn{3}{|c|}{ Water-level altitude (meters) } & \multirow{2}{*}{$\begin{array}{l}\text { Range } \\
\text { (meters) }\end{array}$} & \multirow{2}{*}{$\begin{array}{c}\text { Number of } \\
\text { measure- } \\
\text { ments }\end{array}$} \\
\hline & Maximum & Minimum & Average & & \\
\hline $\begin{array}{r}1_{1} 1963 \\
2_{1964} \\
3_{1986} \\
4_{1987} \\
{ }^{5} 1988 \\
1989\end{array}$ & $\begin{array}{l}728.8 \\
728.6 \\
728.14 \\
728.41 \\
728.53 \\
728.49\end{array}$ & $\begin{array}{l}728.2 \\
728.4 \\
728.03 \\
728.33 \\
728.41 \\
728.40\end{array}$ & $\begin{array}{l}728.5 \\
728.5 \\
728.08 \\
728.38 \\
728.45 \\
728.45\end{array}$ & $\begin{array}{l}0.6 \\
0.2 \\
0.11 \\
0.08 \\
0.12 \\
0.09\end{array}$ & $\begin{array}{l}5 \\
2 \\
2 \\
3 \\
3 \\
8\end{array}$ \\
\hline
\end{tabular}

${ }^{1}$ January, February, November, and December measurements. Reported to

$0.1 \mathrm{~m}$, depth below land surface.

2 February measurements. Reported to $0.1 \mathrm{~m}$, depth below land surface.

${ }^{3}$ September.

4 March, May, December.

5 March, July, October.

7. Bar graph of annual maximum, minimum, and average water-level altitudes (plotted from data in section 6):

$J-13$

Site 1D: 364828116234001

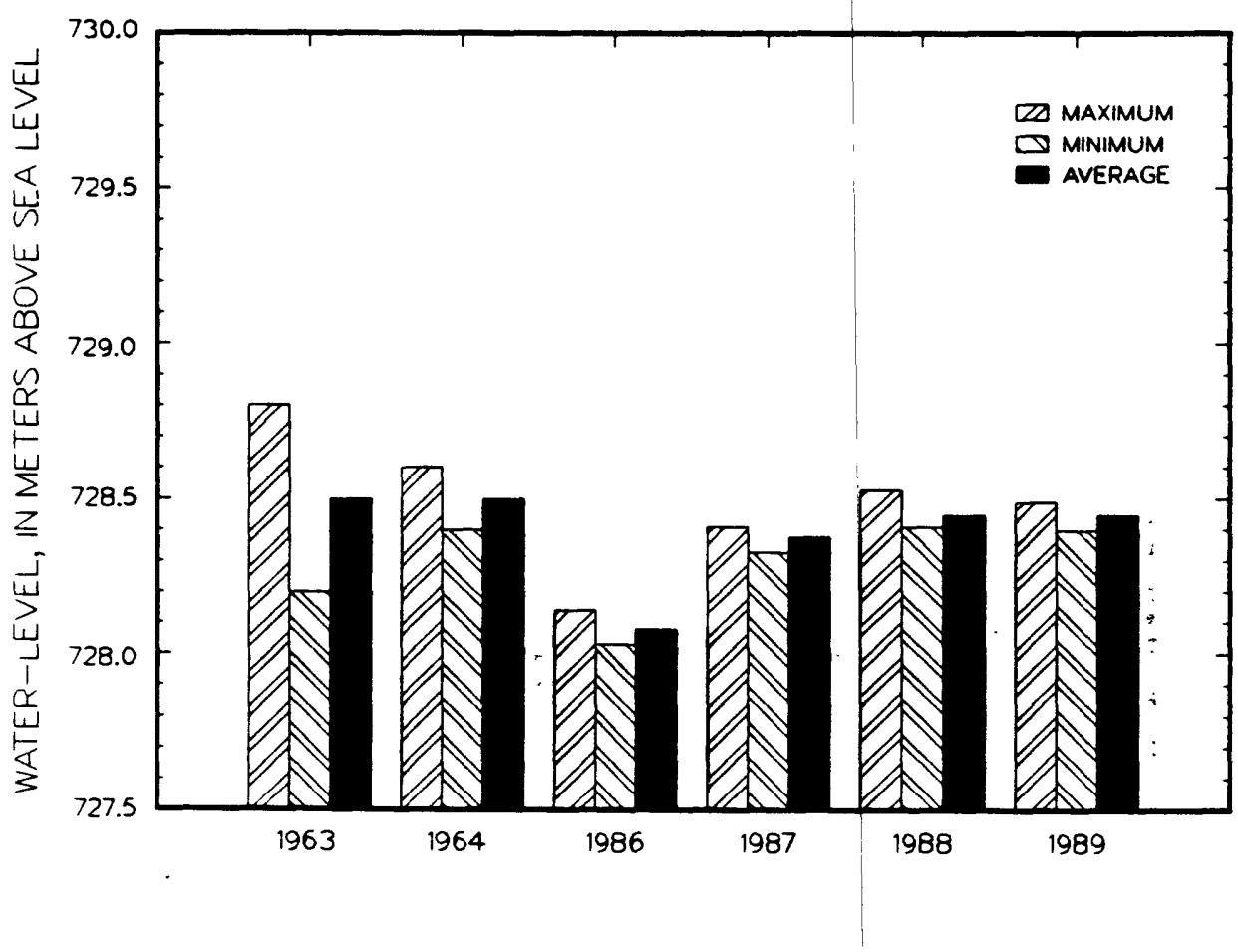




\section{REFERENCES CITED}

Fenix \& Scisson, Inc., 1986a, NNWSI hole histories--UE-25 WT 非, UE-25 WT 非4, UE-25 WT 非, UE-25 WT 非, UE-25 WT 非12, UE-25 WT 非13, UE-25 WT 非14, UE-25 WT 非15, UE-25 WT 非16, UE-25 WT 非17, UE-25 WT 非18, USW WT-1, USW WT-2, USW WT-7, USW WT-10, USW WT-11: U.S. Department of Energy Report DOE/NV/10322-10, 111 p. (HQS.880517.1199) 1986b, NNWSI hole histories--USW VH-1, USW VH-2: U.S. Department of Energy Report DOE/NV/10322-17, 57 p. (NNA.870317.0155) 1987, NNWSI drilling and mining summary: U.S. Department of Energy Report DOE/NV/10322-24, 45 p. (NNA.870624.0037)

Garber, M.S., and Koopman, F.C., 1968, Methods of measuring water levels in deep wells: U.S. Geological Survey Techniques of Water-Resources Investigations, book 8, chap. Al, 23 p. (NNA.900104.0472)

Gemmell, J.M., 1990, Water levels in periodically measured wells in the Yucca Mountain area, Nevada, 1988: U.S. Geological Survey Open-File Report 90-113, 47 p. (NNA.900221.0001)

Robison, J.H., 1984, Ground-water level data and preliminary potentiometricsurface maps, Yucca Mountain and vicinity, Nye County, Nevada: U.S. Geological Survey Water-Resources Investigations Report 84-4197, 8 p. (NNA.870519.0096)

Robison, J.H., 1986, Letter from J.H. Robison (U.S. Geological Survey, Lakewood, Colorado) to D.L. Vieth (U.S. Department of Energy/Nevada Operations Office, Las Vegas, Nevada), September 17, 1986; regarding revisions of Yucca Mountain water levels reported in Robison, 1984. (HQS.880517.1935)

Robison, J.H., Stevens, D.M., Luckey, R.R., and Baldwin, D.A., 1988, Water levels in periodically measured wells in the Yucca Mountain area, Nevada, 1981-87: U.S. Geological Survey Open-File Report 88-468, 132 p. (NNA.890306.0113)

Sass, J.H., and Lachenbruch, A.H., 1982, Preliminary interpretation of thermal data from the Nevada Test Site: U.S. Geological Survey Open-File Report $82-973,30 \mathrm{p}$. (HQS.880517.1427)

Snyder, J.P., 1987, Map projections--A Working Manual: U.S. Geological Survey Professional Paper 1395, 383 p. (NNA.910620.0002)

Thordarson, William, 1983, Geohydrologic data and test results from well J-13, Nevada Test Site, Nye County, Nevada: U.S. Geological Survey WaterResources Investigations Report 83-4171, 57 p. (NNA.870518.0071)

Thordarson, William, and Howells, Lewis, 1987, Hydraulic tests and chemical quality of water at well USW VH-1, Crater Flat, Nye County, Nevada: U.S. Geological Survey Water-Resources Investigations Report 86-4359, 20 p. (NNA.890922.0289)

U.S. Department of Energy, 1988, Site characterization plan, Yucca Mountain site, Nevada research and development area, Nevada: U.S. Department of Energy Report DOE RW/0199, 8 v., various pagination. (HQS.881201.0002)

Waddell, R.K., 1982, Two-dimensional, steady-state model of ground-water flow, Nevada Test Site and vicinity, Nevada-California: U.S. Geological Survey Water-Resources Investigations Report 82-4085, 77 p. (NNA.870518.0055)

Young, R.A., 1972, Water supply for the Nuclear Rocket Development Station at the U.S. Atomic Energy Commission's Nevada Test Site: U.S. Geological Survey Water-Supply Paper 1938, 19 p. (NNA.870519.0070) 